\title{
IDENTIFICAÇÃO E CARACTERIZAÇÃO DE UM PROMOTOR DE CANA-DE-AÇÚCAR INDUZIDO POR HERBIVORIA
}

\author{
PATRÍCIA POMPERMAYER
}

Engenheiro Agrônomo

Orientador: Prof. Dr. MARCIO DE CASTRO SILVA FILHO

Tese apresentada à Escola Superior de Agricultura "Luiz de Queiroz", Universidade de São Paulo, para obtenção do título de Doutor em Agronomia, Área de Concentração:

Genética e Melhoramento de Plantas.

\author{
PIRACICABA \\ Estado de São Paulo - Brasil \\ Maio - 2004
}




\section{Eirrata}

PATRÍCIA POAPERMAYER Identifạcação, e caracterização de iim promator de cana-de-açíçă induzido por lierbivoria

\begin{tabular}{|c|c|c|c|}
\hline & ítem & linhation & onde se lế, \\
\hline 03 & 2.1 & décima oitava & ... Saccharum officinarum,... \\
\hline 19 & 2.3 .2 & nona e décima nona & $\ldots$ da via octadecanóide, ... \\
\hline 26 & 2.5 .1 & quinta e sexta & $\begin{array}{l}\text {... (proteínas que se ligam a } \\
\text { carboidratos e carregam um domínio } \\
\text { heveína) ... }\end{array}$ \\
\hline 36 & 3.1.2.3 & nona & $\begin{array}{l}\text { Cistatina-CIS (inibidor de } \\
\text { proteinase - PIN2 em Korth \& }\end{array}$ \\
\hline 54 & 3.2 .2 .1 & $\begin{array}{l}\text { Figura } 6 \text { - parte } \\
\text { sunerior }\end{array}$ & 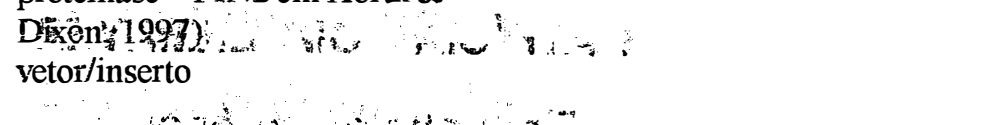 \\
\hline 58 & 3.2.2.1 & terceira & AD2:S'NGCGATGC)?(A/T) AB2:5NG \\
\hline
\end{tabular}

\section{$\begin{array}{lll}65 & 3.2 .9 \quad \text { sexta }\end{array}$}

$\begin{array}{lll}65 & 3.2 .9 \quad \text { décima primeira }\end{array}$

65 3.2.9.1 vigésima sexta $\mathrm{e}$ vigésima sétịịa
... induzido por ferimento ... ... extremidade $3^{\prime}$... ... para facilitar a clonagem, e focam preparados de forma a estarem em fàde de leftura , 1 com o vetor de expressão em plantas.

$77 \quad 4.1$

$78 \quad 4.1 .1$

$79 \quad 4.1 .1$

$96 \quad 4.2 .1 .1 .1$

segunda da legenda da Figura 10

primeira da legenda da Figura 11

segunda da legenda da Figura 12

98 primeira da legenda blast da Figura $29, \quad \cdots$

98 4.2.1.1,2 primeira da legenda blast : da Figura 31

101 4.2.1.1.2 segunda do títúlo da ... por Diatraètisấcharalis Tabela 10

$120 \quad 4.2 .6 .4 \quad$ Figura 50 - parte superior no canto esquerdo
... induzido por herbivoria ...

... extremidade 5 '...

... para facilitar a clonagem. reads

reads

reads

blast $\mathrm{x}$

blast $\mathrm{x}$

... por Diatraea saccharalis $(+=$ fita codante $\mathrm{e}-=$ fita não codante)

HEL...AATGCATCT ... 
Dados Internacionais de Catalogação na Publicação (CIP)

DIVISÃO DE BIBLIOTECA E DOCUMENTAÇĀO - ESALQJUSP

\section{Pompermayer, Patricia}

Identificação e caracterizaçāo de um promotor de cana-de-açúcar induzido por herbivoria / Patricia Pompermayer. - - Piracicaba, 2004.

142 p. : il.

Tese (doutorado) - - Escola Superior de Agricultura Luiz de Queiroz, 2004.

Bibliografia.

1. Brocas (Insetos nocivos) 2. Cana-de-açúcar 3. Clonagem 4. Expressāo gênica 5. Insetos fitófagos 6 . Interaçāo planta-inseto 7 . Tecido vegetal 8 . Transformaçāo genética I. Titulo

CDD 633.61

"Permitida a cópia total ou parcial deste documento, desde que citada a fonte - 0 autor" 
AOS MEUS PAIS, ROSA MARIA E WALTER

E AO MEU MARIDO UMBERTO

OFEREÇO

A TODOS QUE AJUDARAM NA REALIZAÇĀO DESSE TRABALHO, 


\section{AGRADECIMENTOS}

Ao Prof. Dr. Marcio de Castro Silva Filho, do Departamento de Genética (ESALQ/USP), pela indispensável orientação, amizade, atenção, paciência e incentivo em todos os momentos;

À FAPESP, Fundação de Amparo à Pesquisa do Estado de São Paulo, pela concessão de bolsa de estudo;

Ao Departamento de Genética pela oportunidade e apoio técnico para realizar esse trabalho;

Aos professores, alunos e funcionários do Departamento de Genética, ESALQ-USP;

Aos colegas do Laboratório de Biologia Molecular de Plantas e ao técnico Rafael Colombi, ESALQ-USP pelas constantes ajudas, agradável convivência, e eterna amizade;

Ao colega Dr. Reinaldo M. Barata pela amizade, atenção e intensa e necessária ajuda nas metodologias;

Ao Phellippe Arthur Santos Marbach pela ajuda nas análises de bioinformática; 
Ao Daniel Scherer de Moura pela atenção e pelas importantes contribuições e sugestões a esse trabalho;

Aos colegas do Laboratório de Biologia Celular, ESALQ-USP, pela amizade e a Prof ${ }^{a}$. Dra. Maria Lúcia Carneiro Vieira por substituir o orientador nos momentos necessários;

Ao Prof. Dr. José Roberto Postali Parra e à Neide Graciano Zério, do Departamento de Entomologia, Fitopatologia e Zoologia Agricola (ESALQ/USP), pela amizade e por ter fornecido lagartas da broca da cana (Diatraea saccharalis);

Ao Prof. Dr. Luiz Eduardo Aranha Camargo e a Daniela Truffi do Laboratório de Entomologia, Fitopatologia e Zoologia, ESALQ-USP, pelas facilidades de seqüenciamento;

Ao Prof. Dr. Paulo Arruda por disponibilizar o uso de seu laboratório para realização do Northem Blot;

Aos colegas Fábio Tebaldi Silveira Nogueira e Vicente Eugênio de Rosa Júnior do Centro de Biologia Molecular e Engenharia Genética da Unicamp (CBMEG), pela amizade inestimável e intenso apoio na realização do Northem Blot;

Ao Centro de Tecnologia Copersucar e funcionários, por prontamente fornecer todas as plantas de cana-de-açúcar e também lagartas de Diatraea saccharalis utilizadas nesse trabalho e permitir colaboração que foi imprescindivel para realização desse trabalho; 
Ao Eugênio César Ulian, do Centro de Tecnologia Copersucar, pela amizade, oportunidade e atenção a esse trabalho;

A Dra. Maria Cristina Falco, do Centro de Tecnologia Copersucar, pela transformação das plantas de cana-de-açúcar e ajuda na análise das mesmas;

A Dra. Sabrina M. Chabregas, do Centro de Tecnologia Copersucar, pelo apoio e amizade;

À minha família, pela paciência, estímulo e apoio nos momentos difíceis, de maneira muito especial:

- Aos meus pais Walter e Rosa Maria Tolini Pompermayer que sempre me incentivaram e ajudaram;

- Ao meu esposo Umberto Antonio Sesso Filho pela paciência, amor, incentivo, compreensão e ajuda;

- Ao meu tio Alfredo Alberico Botezelli Tolini pela ajuda e paciência em fotografar os experimentos e à sua esposa Roberta pela compreensão e amizade. 


\section{SUMÁRIO}

Página

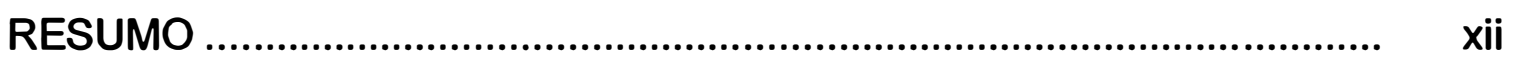

SUMMARY .............................................................................. xiv

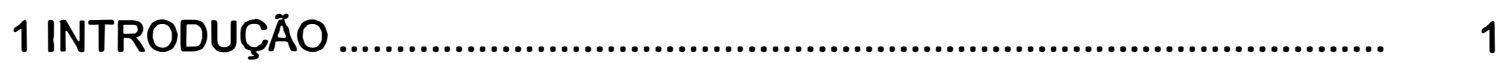

2 REVISẢO DE LITERATURA …………………………………........

2.1 A Cana-de-açúcar (Saccharum officinarum) ………………………..... 3

2.2 Broca da cana-de-açúcar (Diatraea saccharalis) (Fabricius, 1794)

(Lepidoptera, Pyralidae) .................................................................... 4

2.3 Interação planta x inseto ...................................................................... 7

2.3.1 Mecanismos de defesa da planta contra $o$ ataque de insetos............. $\quad 7$

2.3.2 Vias de sinalização......................................................................... 17

2.4 Regulação da expressão gênica ........................................................ 20

2.4.1 Estrutura dos promotores de plantas ............................................... 21

2.4.2 Sistema de expressão constitutiva ................................................... 23

2.4.3 Sistema de expressão induzida........................................................ 24

2.5 Os genes heveína e tipo heveína (HEL) ............................................... 25

2.5.1 Características gerais da heveina e tipo heveína................................ 25

2.5.2 Classificação das quitinases .......................................................... 26

2.5.3 Complexidade da família do gene HEL ........................................... 28

2.4.4 Possivel papel das proteínas do tipo heveína na defesa contra patógenos.................................................................................. 29

2.3.5 As proteinas dos genes PR como inseticidas ..................................... 31

2.5.6 Regulação transcricional da expressão do gene PR.......................... 32

3 MATERIAL E MÉTODOS .................................................................. 34 
3.1 Estudo da expressão gênica em cana-de-açúcar

3.1.1 Estudo da expressão gênica em cana-de-açúcar por meio da análise assistida por computador

3.1.2 Análise da expressão gênica por meio da técnica Northern Blot 34

3.1.2.1 Plantas de cana-de-açúcar. 35

3.1.2.2 Insetos 35

3.1.2.3 Indução da expressão gênica por herbivoria nas plantas de cana-de-açúcar.

3.1.2.4 Isolamento do RNA 37

3.1.2.4 1 Homogeneização 38

3.1.2.4.2 Fase de separação. 39

3.1.2.4.3 Precipitação. 39

3.1.2.4.4 Lavagem do RNA 39

3.1.2.4.5 Solubilização do RNA 40

3.1.2.4.6 Quantificação do RNA total 40

3.1.2.4.7 Integridade do RNA e quantificação. 40

3.1.2.4.8 Armazenamento do RNA. 42

3.1.2.5 Manuseio do RNA 42

3.1.2.5.1 Cuidados gerais 42

3.1.2.5.2 Plásticos 42

3.1.2.5.3 Vidraria 43

3.1.2.5.4 cubas de eletroforese 43

3.1.2.5.5 soluções 43

3.1.2.6 Confirmação do cDNA recebido. 43

3.1.2.7 Isolamento do plasmídeo 44

3.1.2.8 Seqüenciamento dos cDNAs. 45

3.1.2.8.1 Células competentes. 46

3.1.2.8.2 transformação bacteriana (Escherichia coli)

3.1.2.9 Preparo das sondas para análise da expressão gênica por meio da técnica de Northern Blot. 
3.1.2.10 Transferência e fixação de RNA na membrana............................ 48

3.1.2.11 Marcação da sonda ................................................................. 50

3.1.2.12 Pré-hibridização ................................................................ 50

3.1.2.13 Hibridização........................................................................... 51

3.2 Identificação e caracterização de promotores de genes de

cana-de-açúcar induzidos por herbivoria ........................................... 52

3.2.1 Extração de DNA ....................................................................... 52

3.2.2 Técnica PCR-TAIL (thermal asymmetric interlaced) ........................ 53

3.2.2.1 Primeira etapa........................................................................ 53

3.2.2.2 Segunda etapa.................................................................. 60

3.2.3 Purificação dos fragmentos amplificados pela técnica PCR-TAIL...... 62

3.2.4 Clonagem dos produtos do PCR-TAIL ......................................... 62

3.2.5 Avaliação da transformação por PCR diretamente nas bactérias ....... 63

3.2.6 Minipreparação de DNA de plasmídeo das colônias bacterianas selecionadas, usando lise-alcalina.................................................. 63

3.2.7 Sequenciamento dos fragmentos obtidos nas reações PCR-TAIL...... 64

3.2.8 Busca por motivos regulatórios ....................................................... 64

3.2.9 Caracterização do promotor induzido por ferimento.......................... 65

3.2.9.1 Construções gênicas .................................................................. 65

3.2.10 Construção dos vetores para transformação................................... 66

3.2.11 Transformação de plantas de cana-de-açúcar............................... 68

3.2.12 Identificação de plantas de cana-de-açúcar transgênicas por reação em cadeia da polimerase (PCR) ................................................. 69

3.2.12.1 Isolamento de DNA genômico de plantas de cana-de-açúcar........ 69

3.2.12.2 Reação em cadeia da polimerase (PCR) .................................... 69

3.2.13 Análise molecular dos promotores .............................................. 71

3.2.13.1 Expressão transiente em células de epiderme de cebola .............. 71

3.2.13.2 Transformação ...................................................................... 71

3.2.13.3 Atividade da GUS ............................................................... 72

3.2.13.4 Ensaio biológico com as plantas de cana-de-açúcar transgênicas 73 
3.2.14 Ensaio histoquímico da enzima ß-glucuronidase (GUS) ................. 74

3.2.15 Ensaio fluorimétrico da enzima ß-glucuronidase (GUS).................. 74

3.2.16 Análise comparativa entre a região promotora do gene tipo heveína (HEL) de cana-de-açúcar e de Arabidopsis..................................... 75

4 RESULTADOS E DISCUSSĀO........................................................... 76

4.1 Estudo da expressão gênica em cana-de-açúcar ................................ 76

4.1.1 Estudo da expressão gênica em cana-de-açúcar por meio da análise assistida por computador 76

4.1.2 Análise da expressão gênica por meio da técnica Northerm Blot ....... 79

4.1.2.1 Gene da $\beta$-actina ..................................................................... 80

4.1.2.2 Gene LOX2 (lipoxigenase) ..................................................... 80

4.1.2.3 Gene PPO (polifenol oxidase) ..................................................... 82

4.1.2.4 Gene cistatina (CIS) ............................................................. 84

4.1.2.5 Gene MT1 (metalotioneina)....................................................... 87

4.1.2.6 Gene HEL (proteína tipo Heveína) .............................................. 88

4.2 Identificação e caracterização de promotores de genes de

cana-de-açúcar induzidos por herbivoria.............................................. 91

4.2.1 Identificação de promotores de genes de cana-de-açúcar induzidos por herbivoria................................................................................ 91

4.2.1.1 Primeira etapa ..................................................................... 92

4.2.1.1.1 Gene PPO (polifenol oxidase) ................................................ 94

4.2.1.1.2 Gene HEL........................................................................... 97

4.2.1.2 Segunda etapa .................................................................. 102

4.2.2 Caracterização do promotor induzido por ferimento......................... 104

4.2.3 Construção dos vetores para transformação.................................... 107

4.2.4 Transformação de plantas de cana-de-açúcar ................................. 108

4.2.6 Análise molecular dos promotores ................................................ 111

4.2.6.1 Expressão transiente em células epidérmica de cebola................. 111

4.2.6.2 Regulação por herbivoria .......................................................... 112

4.2.6.3 Ensaio histoquímico e fluorimétrico da enzima 
ß-glucuronidase (GUS) ......................................................... 113

4.2.6.3.1 Ensaio histoquímico ......................................................... 113

4.2.6.3.2 Ensaio fluorimétrico ........................................................ 118

4.2.6.4 Análise comparativa entre as prováveis regiōes promotoras

do gene tipo heveína (HEL) de cana-de-açúcar e de Arabidopsis ... 119 5 CONCLUSÕES ............................................................................ 123

REFERÊNCIAS BIBLIOGRÁFICAS .............................................. 124 


\title{
IDENTIFICAÇÃO E CARACTERIZAÇÃO DE UM PROMOTOR DE CANA-DE- AÇÚCAR INDUZIDO POR HERBIVORIA
}

\author{
Autora: PATRÍCIA POMPERMAYER \\ Orientador: Prof. Dr. MARCIO DE CASTRO SILVA FILHO
}

\section{RESUMO}

Uma fonte particularmente comum de injúrias em plantas são os insetos fitófagos. Ao se alimentarem, os insetos induzem um rápido acúmulo de proteínas de resposta ao ferimento ao longo da planta. Poucos trabalhos têm caracterizado a expressão de genes induzidos por insetos herbivoros. No caso de monocotiledôneas, praticamente estas informações são inexistentes. Desse modo, inicialmente foi caracterizada a expressão de genes de cana-de-açúcar (uma planta monocotiledônea) cujos ortólogos foram previamente reportados como responsivos ao ataque de pragas em dicotiledôneas. Assim sendo, foram feitos ensaios de indução da expressão de genes por hebivoria utilizando lagartas de Diatraea saccharalis. A análise da expressão dos genes nas plantas de cana foi realizada por Northern Blot utilizando-se como sondas seqüências expressas (ESTs) obtidas no banco de dados do Projeto SUCEST/FAPESP. Foram utilizadas as seguintes sondas: polifenol oxidase (PPO), lipoxigenase (LOX2), metalotioneína (MT1), proteína tipo heveina (HEL), a cistatina (CIS) e a $\beta$-actina como controle interno. Os resultados mostraram que os genes $P P O$ e HEL tiveram sua expressão significativamente aumentada (de 10 a 12 vezes) 
em relação ao controle. A expressão dos genes CIS, MT1 e LOX2 também foi aumentada, apesar de ser inferior aos genes PPO e HEL. Com base nos estudos de expressão foram escolhidos os genes HEL e PPO para a identificação e caracterização de promotores de cana-de-açúcar induzidos por herbivoria. Uma vez clonada a região promotora do gene HEL de aproximadamente $1100 \mathrm{pb}$, foram feitos buscas de seqüências regulatórias que revelaram a presença de seqüências relacionadas à defesa de plantas. Em seguida três deleções a partir da extremidade 5' nessa região foram realizadas e fusionadas de forma a dirigirem a expressão do gene repórter uidA (GUS). Essas construções foram expressas em plantas de cana-de-açúcar, a fim de estudar sua regulação em resposta a hebivoria. Os resultados mostraram que a região promotora é positivamente regulada por hebivoria. Os resultados desse estudo contribuem para novas perspectivas na expressão heteróloga de genes com propriedades inseticidas em cana-de-açúcar. 


\title{
IDENTIFICATION AND CHARACTERIZATION OF A SUGARCANE PROMOTER INDUCED BY HERBIVORY
}

\author{
Author: PATRICCIA POMPERMAYER \\ Adviser: Prof. Dr. MARCIO DE CASTRO SILVA FILHO
}

\section{SUMMARY}

A particularly common source of wounding in plants is caused by herbivore insects. In monocotyledonous plants, the defense mechanisms against herbivores are still poorly understood and few studies have addressed the expression of genes induced by herbivore insects. In the present study it has been characterized the sugarcane responses to the attack of the sugarcane borer (Diatraea saccharalis) by analyzing the expression of a set of genes whose orthologues have been shown to be related to insect attack in dicotyledonous plants. Gene expression analysis was performed by Northern Blot. The following Expressed Sequence Tags (ESTs) obtained from the cluster consensi bank of Sugarcane EST Transcriptome Project (SUCEST) were used as probes: polyphenol oxidase (PPO), lipoxygenase (LOX2), hevein-like protein (HEL), cystatin (CYS) and $\beta$-actin (internal control). The results showed that $P P O$ and HEL gene expression increased by 10 to $12-$ fold in relation to the control. The expression of CYS, MT1 and LOX2 genes were also increased, although as not as the same extent for PPO and HEL 
genes. Based on these expression studies the cloning of the HEL and PPO promoter regions was attempted. After cloning a 1100 bp fragment corresponding to the 5' upstream region of the sugarcane HEL coding sequence, the search for regulatory sequences involved on plant defense was performed. Soon after three deletions of the promoter region were carried out and the resulting fragments were fused to the uidA (GUS) reporter gene. These gene constructs were expressed in sugarcane plants in order to study its regulation in response to hebivory. The results showed that the promoter region is positively regulated by hebivory. The results of that study bring new insights on heterologous expression of insect resistant genes in sugarcane plants. 


\section{INTRODUÇÃO}

A cana-de-açúcar é uma cultura de grande importância econômica para alguns países das Américas, especialmente o Brasil, que apresenta a maior área cultivada. Entretanto, fatores bióticos como o ataque de inúmeros insetos pragas constituem-se muitas vezes em fatores limitantes à produção sucroalcooleira.

Nas últimas décadas, pesquisadores vêm estudando a biossíntese e regulação de produtos químicos específicos em plantas associados com a defesa contra pragas e patógenos.

Durante anos, muitos destes compostos químicos foram inicialmente considerados como componentes secundários das plantas com funções desconhecidas.

Atualmente, muitos desses componentes secundários são considerados como químicos defensivos que estão agindo sozinhos ou em conjunto conferindo resistência às plantas contra insetos ou patógenos.

O ferimento mecânico ou provocado por insetos herbívoros nos tecidos de plantas causa rápidas mudanças na expressão de genes no local dos tecidos injuriados. Genes que são expressos nos tecidos feridos são referidos como genes que codificam proteínas induzidas pelo ferimento (PIFs). O sinal de ferimento é também transmitido para tecidos não feridos de modo a ativar a expressão das PIFs impedindo que a praga se espalhe.

As funções de diversas PIFs são bem conhecidas, incluindo proteinases, inibidores de proteinases (IPs), proteínas envolvidas na biossíntese de 
metabólitos secundários de plantas, proteínas envolvidas na vias de transdução de sinal, etc.

Alguns estudos têm indicado que a injúria das plantas por insetos resulta em respostas fisiológicas e bioquímicas específicas quando comparadas ao dano mecânico sozinho. Estes genes são de grande interesse na transformação de plantas visando à resistência a insetos.

Embora um promotor constitutivo forte seja útil para a expressão eficiente de um transgene em células vegetais, uma regulação mais precisa da expressão usando promotores induziveis pode ser uma característica vantajosa, particularmente quando a produção da proteina codificada pelo transgene é desfavorável ao crescimento da planta hospedeira.

Além disso, praticamente todos os promotores usados até o presente momento são patenteados e, portanto, são objeto de assinatura de termos de transferência de material biológico. Isso dificulta a utilização comercial das plantas no país.

Assim sendo, para que se possa utilizar-se desta tecnologia no país com genes de interesse, é imperativo que sejam identificados novos promotores, de expressão constitutiva, tecido-específicos, e/ou ativados sob determinadas situações de estresse.

Portanto, o presente trabalho visou a identificação e caracterização de promotores de cana-de-açúcar induzidos por herbivoria. 


\section{REVISÃO DE LITERATURA}

\subsection{A Cana-de-açúcar (Saccharum officinarum)}

A cana-de-açúcar é uma cultura de grande importância econômica para alguns países das Américas, especialmente o Brasil, que apresenta a maior área cultivada (FNP consultoria \& comércio, 2004).

O Estado de São Paulo e parte do Triângulo Mineiro, devido à fatores climáticos e de logística, tornam-se juntos a principal área sucroalcooleira do mundo (Abrantes, 2003).

Na macrorregião de Piracicaba, que compreende 33 municípios e reúne 4.500 canavieiros e $39 \%$ dos produtores de São Paulo, 200 mil hectares de cana são plantados atualmente. Foram colhidas, na safra 03/04, 24 milhões de toneladas de cana, $7 \%$ a mais do que a safra passada, o equivalente a $14 \%$ da produção do Estado de São Paulo (Setto, 2004).

A cana-de-açúcar pertence a família das gramíneas (Poaceae), uma família economicamente importante que inclui os cereais como milho, trigo, arroz e sorgo bem como culturas forrageiras. Seu principal produto é a sacarose, a qual acumulada-se no colmo.

A cana cultivada, Saccharum officinarum, vem sendo melhorada ao longo das décadas por meio de centenas

de cruzamentos. Como conseqüência, as variedades atualmente são altamente poliplóides e aneuplóides, com número de cromossomos variando de 100-130. Apesar da complexidade, a quantidade de informações disponiveis para 0 
genoma da cana-de-açúcar vem aumentando. No entanto, devido ao alto nível de ploidia, inexiste um mapa completo (Vettore et al., 2003).

A identificação de novos genes em cana-de-açúcar foi bastante limitada até um passado recente. Alguns genes, a maioria deles envolvidos no metabolismo da sacarose, foram identificados a partir da década de 90 (Bugos \& Thom, 1993).

Projetos de seqüências expressas (EST, Expressed Sequence Tag) fornecem ferramentas muito úteis para acesso rápido a informações da seqüência do gene (Vettore et al. 2003).

Vettore et al. (2001) no projeto SUCEST (Sugarcane Expressed Sequence Tag) implementaram um procedimento eficiente para gerar bibliotecas de cDNA convencional para gerar ESTs de cana-de-açúcar em larga escala. Com isso, foram construídas bibliotecas de cDNA, representando os principais órgãos, em diferentes estágios de desenvolvimento, para gerar uma das maiores coleções de ESTs de plantas.

2.2 Broca da cana-de-açúcar (Diatraea saccharalis) (Fabricius, 1794) (Lepidoptera, Pyralidae)

A cultura da cana-de-açúcar, no Estado de São Paulo, sofre o ataque de inúmeros insetos pragas, os quais constituem-se, muitas vezes, em fatores limitantes à produção sucro-alcooleira. Dentre esses, destaca-se a broca-dacana, Diatraea saccharalis (Fabricius, 1794), que é a praga mais importante da cultura no Brasil, não só pelos danos econômicos que ocasiona à agroindústria sucro-alcooleira, mas também pelas dificuldades de controle que apresenta devido basicamente ao seu hábito alimentar (Vendramin, 1987).

O adulto da broca-da-cana é uma mariposa de hábitos noturnos, que realiza a postura na parte dorsal das folhas. Após o nascimento as lagartas descem pela folha e penetram no colmo, perfurando-o na região nodal. Dentro 
do colmo, cavam galerias onde permanecem até o estádio adulto (Sgrillo, 1979).

Estima-se que $13 \%$ das perdas na produção agrícola, em todo o mundo, são devido à insetos (Jouanin et al., 1998).

No Brasil, a perda de produção por causa do ataque de insetos é de $7,1 \%$, em média, variando de 2 a $30 \%$. Na cultura da cana-de-açúcar as perdas devido aos insetos é de aproximadamente $10 \%$ do valor total de produção (Bento, 1999) sendo a broca da cana, pelos danos que causa e pela sua disseminação, uma das principais pragas desta cultura.

A broca ataca a cultura da cana, desde a germinação dos toletes até o colmo maduro, colhido para a moagem. É no estado de lagarta - broca- que o inseto é mais conhecido.

Ao nascerem as lagartas medem aproximadamente $1 \mathrm{~mm}$ de comprimento, sendo que a cabeça tem o comprimento 1,5 vezes maior que o diâmetro do corpo (Valsechi et al., 1976). Quando completamente desenvolvida, a lagarta da broca da cana mede cerca de $25 \mathrm{~mm}$ de comprimento por aproximadamente 3 a $3,5 \mathrm{~mm}$ de diâmetro. As lagartas desse inseto, após eclodirem dos ovos, permanecem no colmo da planta até completarem a fase larval (Sgrillo, 1979).

A broca da cana causa danos na cana planta a partir do terceiro mês após o plantio, quando ocorre a formação dos primeiros internódios. Inicialmente os danos são observados em brotos ou perfilhos novos que têm sua gema apical afetada pelas lagartas da praga, resultando na morte da gema e das folhas mais novas e, posteriormente, seca e morte do broto ou perfilho atacado. Este sintoma é conhecido como "coração morto" e, permite visualizar a condição inicial de infestação de um canavial (Sgrillo, 1979).

A morte da gema apical nos colmos em desenvolvimento causa o secamento das folhas induzindo a brotação das gemas laterais e enraizamento aéreo, fatos que contribuem negativamente na produção e na qualidade da matéria prima (Sgrillo, 1979). 
Outro tipo de dano é causado pela praga no interior do colmo escavando galerias e alimentando-se dos tecidos. As galerias longitudinais nos colmos provocam a perda de açúcar e, as galerias circulares escavadas nos colmos causam a quebra das canas, interferindo de maneira significativa na produção de cana e no seu teor de açúcar (Castilho, 1982; Bastos, 1987).

Além disso, através dos orifícios abertos pelas lagartas, ocorre a penetração de fungos dos gêneros Fusarium e Colletrotichum, que causam a podridão vermelha e provocam a inversão da sacarose em glucose e levulose, dificilmente cristalizáveis pelos processos industriais comuns. (Castilho, 1982; Bastos, 1987).

Essas perdas podem provocar reduções de 50 a $70 \%$ da sacarose nos colmos atacados, enquanto que as diminuições de toneladas de cana são menores, variando de 12 a 41,5\% (Bastos, 1987).

Estes danos causados pelos fungos são conhecidos como indiretos já que ocorrem a partir da infestação pela broca da cana.

Para o controle da broca, diversos métodos têm sido tentados ao longo dos anos porém, após sua penetração no interior do colmo, as lagartas estão protegidas contra métodos artificiais de controle sejam eles culturais, mecânicos ou químicos (Guevara, 1976).

Embora o controle químico apresente a curto prazo uma maior eficiência a sua aplicação nos canaviais não apresenta os mesmos resultados efetivos obtidos no controle de pragas em outras culturas, devido, principalmente, a dois fatores: a praga passar a maior parte de sua fase larval dentro do colmo, onde o inseticida não a atinge; e o alto custo, devido ao porte da cultura. Ao mesmo tempo, deve-se considerar a tendência mundial de restringir o uso de pesticidas. Além disso, é sabido que muitas espécies de insetos da ordem Lepidoptera desenvolveram resistência a pesticidas convencionais e, portanto, novos métodos de controle são necessários (Lee \& Anstee, 1995).

O melhoramento genético visando a obtenção de variedades resistentes, o uso de controle biológico e a aplicação de biopesticidas vêm sendo realizados 
com sucesso, embora o desenvolvimento de novas metodologias menos poluentes e onerosas continuam a ser buscadas.

Uma nova estratégica baseada na transferência de genes de resistência a pragas em plantas de interesse econômico via Engenharia Genética tem sido explorada com relativo sucesso (Belzunces et al., 1994).

Dentre os genes em estudo, destacam-se aqueles cujos produtos exercem um efeito antimetabólico (para uma revisão, veja Carlini \& Grossi-deSá, 2002).

\subsection{Interação planta $x$ inseto}

\subsubsection{Mecanismos de defesa da planta contra o ataque de insetos}

As plantas, por centenas de milhões de anos, têm desenvolvido estratégias de defesa para se protegerem contra herbivoros e patógenos (Bergey et al., 1996).

As interações dos insetos herbívoros com as plantas são o resultado de um longo e contínuo processo evolutivo (revisado por, veja Mello \& Silva-Filho, 2002).

A relação inseto-planta é um processo dinâmico em que para cada adaptação da planta, tende a ocorrer uma contra-adaptação do inseto. As causas da resistência em plantas podem ser classificadas em físicas, morfológicas e químicas (Vendramim \& Nishikawa, 2001).

As causa físicas são representadas basicamente pelas cores do substrato vegetal que podem afetar a escolha do hospedeiro para alimentação e oviposição como, por exemplo, a menor oviposição de Pieris rapae em variedades avermelhadas de repolho em relação às esverdeadas (Shelton et al., 1988).

As causas morfológicas são agrupadas em: 
-fatores estruturais (relacionados à dimensão e à disposição das estruturas vegetais) como por exemplo, em cana-de-açúcar onde observou-se menor ataque da broca da cana (Diatraea saccharalis) em variedades com bainhas foliares mais compactadas, já que isso dificulta a penetração das lagartas no colmo (Macedo, 1978);

-fatores da epiderme (espessura, dureza, textura, cerosidade e pilosidade) como, por exemplo, a maior dureza da casca do internódio em cana-de-açúcar é fator de resistência à broca (Martin et al., 1975).

As causas químicas são essencialmente representadas por substâncias químicas que atuam no comportamento ou metabolismo do inseto e por impropriedades nutricionais da planta. A resistência química pode ser dividida em constitutiva e induzida.

Nas últimas décadas, pesquisadores vêm estudando a biossíntese e regulação de produtos químicos específicos em plantas associados com a defesa contra pragas e patógenos. Durante anos, muitos desses químicos foram inicialmente considerados como componentes secundários das plantas com funções desconhecidas. Porém, atualmente muitos destes componentes secundários são considerados como químicos defensivos que estão agindo sozinhos ou em conjunto contribuindo para a resistência de plantas contra insetos ou patógenos (Janzen et al., 1986).

Vários aspectos das respostas das plantas aos danos por insetos estão sendo estudados, entre eles a caracterização de respostas diretas e indiretas, a regulação da expressão gênica resultante do ataque por insetos e as vias de transdução de sinais (Bruxelles \& Roberts, 2001; Gatehouse, 2002)

As plantas desenvolveram um sistema complexo de defesa contra herbívoros e patógenos. Muitas dessas respostas são induzidas e ativadas especificamente como resultado de um dano. Resposta ao ferimento vem sendo assunto de muitos estudos ao longo das últimas três décadas e tem sido adotada como importante sistema modelo para pesquisas de sinalização em plantas (Bruxelles \& Roberts, 2001). 
Estas pesquisas seguiram a descoberta feita por Ryan e colaboradores na década de 70 mostrando que as proteínas de defesa (inibidor de proteinase) acumularam não somente nas folhas de tomate e batata danificadas mecanicamente mas também nas folhas intactas (Green \& Ryan, 1972).

Posteriormente, demonstrou-se que os inibidores de proteinase inibem as enzimas digestivas de insetos herbivoros (revisado por Ryan, 1990). Os inibidores de proteinase são também encontrados como genes induzidos por ferimento em diversas espécies de plantas, desde gramíneas até árvores, e são normalmente usados como gene marcador para resposta ao ferimento .

O ferimento mecânico nos tecidos de plantas causa rápidas mudanças na expressão de genes no local dos tecidos injuriados. Genes que são expressos nos tecidos feridos são referidos como genes que codificam proteinas induzidas pelo ferimento (PIFs). O sinal de ferimento é também transmitido para tecidos não feridos de modo a ativar a expressão das PIFs impedindo que a praga se espalhe. As funções de diversas PIFs são bem conhecidas, incluindo proteinases, inibidores de proteinases (IPs), proteínas envolvidas na biossíntese de metabólitos secundários de plantas, proteínas envolvidas na vias de transdução de sinal (Ryan, 1990; Sticher et al., 1997).

Os inibidores de proteinase atuam impedindo a atividade proteolítica das enzimas digestivas dos insetos (Duan et al., 1996; Pompermayer et al., 2001; Falco \& Silva-Filho, 2003, Pompermayer et al., 2003). Ou ainda, levam à superprodução de enzimas digestivas na tentativa de que algumas delas consigam escapar da ação dos IPs (Broadway et al., 1986; Paulillo et al., 2000; Brito et al., 2001). Isso faz com que aminoácidos destinados à síntese de proteinas essenciais sejam utilizados na formação de proteinases. Entretanto, 0 modo de ação dessa proteinase sobre diferentes insetos praga da ordem Lepidoptera ainda está por ser esclarecido.

As polifenol oxidase (PPO) têm sido relatadas como proteínas antimetabólicas aos insetos devido, à propriedade de reagirem com aminoácidos livres prevenindo a assimilação eficiente de aminoácidos 
alquilados, reduzindo o valor nutritivo da proteina (Felton et al., 1992). Essas proteínas são responsáveis pelo típico escurecimento dos extratos vegetais e tecidos danificados.

As frutas normalmente contêm grandes quantidades de PPO. A função fisiológica da PPO em frutas e outros órgãos de plantas saudáveis ainda é incerta, mas o papel para a PPO em folhas na defesa contra insetos herbivoros vêm sendo proposto e documentado (Constabel et al., 1995; Constabel et al., 2000).

Em alfafa (Medicago sp.), Bellucci et al. (1999) observaram maior atividade da PPO na variedade resistente a insetos quando comparada com a susceptível, sugerindo um possivel papel da PPO na resistência a estresses bióticos. As polifenol oxidase (PPOs) respondem similarmente ao inibidor de protease, os quais catalisam a oxidação de metabólitos fenólicos secundários em quinonas. Quando as PPOs estão combinadas com substratos fenólicos apropriados em tricomas glandulares, elas produzem o equivalente a "super colas" capazes de prender insetos. Quando as PPOs são expressas no mesófilo dos tecidos, elas podem modificar covalentemente e se ligar as proteínas do alimento durante 0 ataque, e assim reduzir a digestibilidade das proteínas no intestino dos insetos (Baldwin \& Preston, 1999).

Segundo Falco et al. (2001), em cana-de-açúcar as PPOs são altamente expressas em meristemas apicais, que produzem o típico escurecimento dos tecidos após o corte ou ferimento e, niveis significantes de mRNA ocorrem nas flores, raízes e zona de transição da raiz.

Resultados obtidos por Constabel et al. (2000) mostraram que em árvores (híbridos de álamo) a proteína PPO, cuja expressão é induzida por ferimento e por insetos, também possui a função de defesa contra o ataque de insetos.

De acordo com Baldwin \& Preston (1999) as plantas respondem ao ataque dos herbivoros com defesas diretas as quais tornam a planta mais resistentes a futuros ataques (Figura 1). 
Algumas dessas defesas podem ser similares às ativadas contra patógenos (Bostock, 1999) mas uma vez que o ataque por herbívoros ocorre em uma escala maior que a do patógenos, as respostas tendem a serem mais sistêmicas (Baldwin \& Preston, 1999).

Exemplos de defesas diretas incluem a produção de metabólitos secundários tal como nicotina, que podem matar o herbívoro ao se alimentar da planta e, proteinas de defesa tais como inibidores de protease ou polifenol oxidase (PPOs) os quais, reduzem a disponibilidade de nutrientes afetando o crescimento dos herbivoros (Baldwin \& Preston, 1999).

Os inibidores de protease são as proteínas de defesa mais estudadas. As concentrações de inibidores são aumentadas drasticamente após o ataque por meio de cascatas de sinais de longa distância (sistemina) e de curta distância (fragmentos de parede celular) os quais induzem a expressão do gene do inibidor via cascata do ácido jasmônico (Koiwa et al., 1997).

Em cana-de-açúcar, pelo menos sete classes de inibidores de serinoproteinases do tipo Bowman-Birk já foram identificadas (Mello et al., 2003).

As plantas utilizam ainda, outras estratégias de defesa denominadas de defesas indiretas que facilitam o controle da população dos insetos por meio de predadores, parasitóides e patógenos. Uma das estratégias utilizadas consiste na liberação de compostos orgânicos voláteis que sinalizam aos predadores e outros membros do terceiro nível trófico da presença do inseto herbívoro (DeMoraes et al., 1998; Figura 1). 


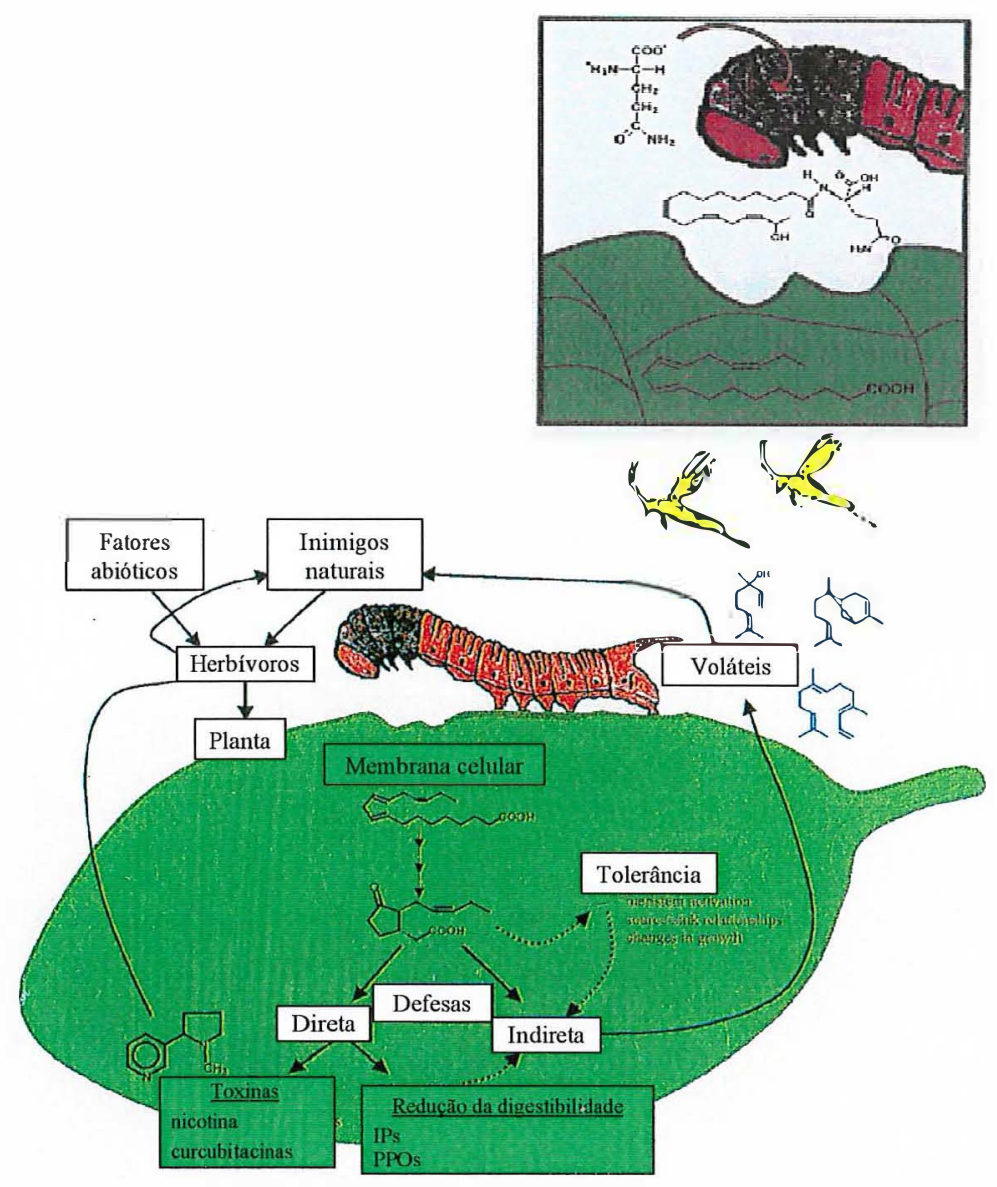

Figura 1 - Defesas diretas e indiretas das plantas em resposta ao ataque de insetos herbivoros

Fonte: Adaptação de Baldwin \& Preston (1999)

Em plantas de tomate, um sinal (ou sinais) originado a partir do local do ferimento é transportado através da planta e ativa a síntese de proteínas de defesa que interferem com o sistema digestivo dos herbivoros (Figura 2) (Bergey, 1996; Gatehouse, 2002).

Essas proteínas de defesa induzidas foram identificadas como sendo inibidores de proteinase do tipo serina, cisteína e aspartil (Ryan, 1990) e polifenol oxidase (Constabel et al., 1995). 


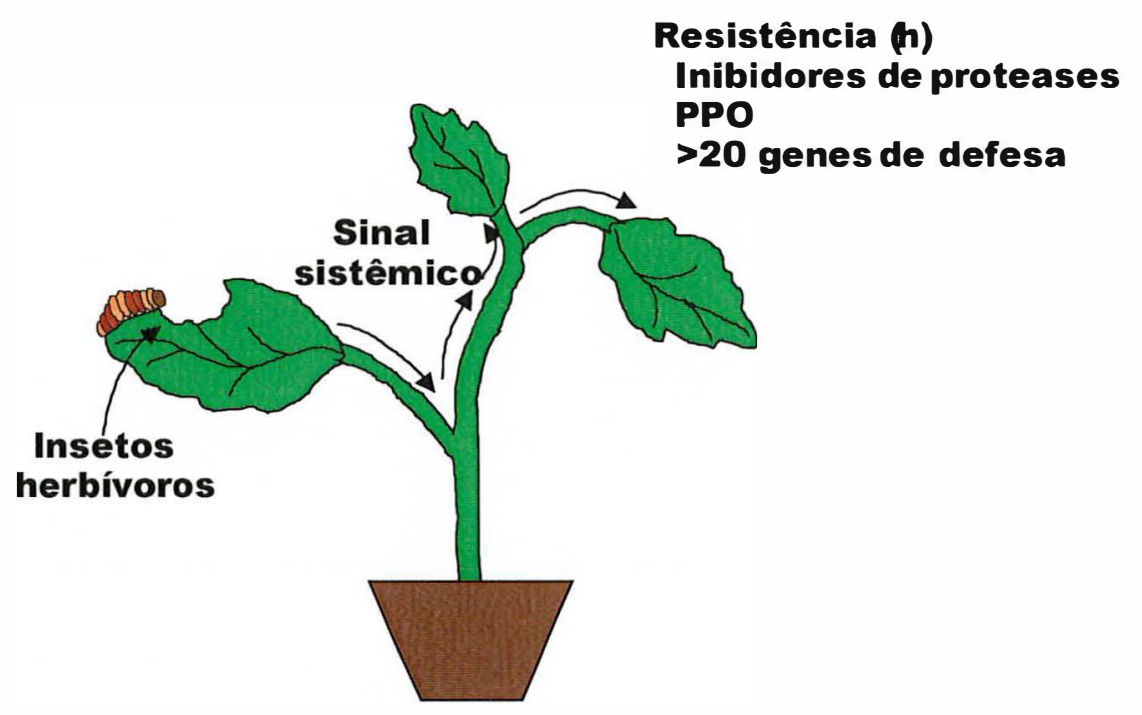

Figura 2 - Dano mecânico induz a sintese de proteínas de defesa de forma sistêmica Fonte: Adaptado de Bergey et al. (1996)

Os inibidores de proteinase interagem com proteinases do intestino dos insetos interferindo na proteólise do alimento ingerido, reduzindo a disponibilidade de aminoácidos essenciais e retardando o crescimento e desenvolvimento dos herbívoros (Ryan, 1990; Constabel et al., 1995).

O efeito desse processo no ecossistema natural resulta na redução do dano na planta por meio da morte do predador ou devido a um maior período de exposição dos herbívoros aos predadores naturais (Bergey, 1996).

A análise comparativa via macroarranjos de DNA de cerca de 4000 ESTs de cana-de-açúcar em um genótipo tolerante e em uma variedade susceptível ao ataque da lagarta Diatraea saccharalis revelou a presença de um grande número de genes ativados ou reprimidos pela herbivoria (Barsalobres et al., manuscrito em preparação).

Segundo Soares-Costa et al. (2002), os inibidores de proteinase atraem a atenção de pesquisadores devido a capacidade de inibir não só as proteases presentes em muitos herbívoros mas também em patógenos.

$\mathrm{Na}$ cultura da cana-de-açúcar, há vários fatores limitantes da produtividade, entre eles está a susceptibilidade a fungos patogênicos como por 
exemplo, o fungo causador da podridão vermelha, em decorrência da presença de lagartas da broca da cana ( $D$. saccharalis). Portanto, sendo o principal meio de controle o uso de fungicidas e pesticidas, que acarretam elevados custos e problemas ambientas, estudos destes inibidores em cana-de-açúcar podem contribuir significativamente para o desenvolvimento de plantas mais resistentes (Soares-Costa et al., 2002).

As cistatinas são inibidores de proteinases cisteínicas, compondo uma superfamília de proteínas evolutivamente relacionadas que está dividida em três familias: a primeira é a das estefinas (composta de proteinas destituídas de pontes de enxofre); a segunda é a das cistatinas (agrupa proteínas que possuem pontes de sulfeto); a terceira família é a dos kininogênios (se caracteriza por ser formada por glicoproteínas de alto peso molecular com três domínios repetidos similares aos da família das cistatinas).

As fitocistatínas constituem uma familia de cistatinas que possui representantes exclusivamente em plantas. Elas são proteinas que não possuem pontes de enxofre e contém uma seqüência conservada na região $\mathrm{N}$ terminal (Reis \& Margis, 2001).

Dessa forma, para identificar possiveis membros da superfamilia das cistatínas presentes no banco de dados de cana-de-açúcar do SUCEST, Reis \& Margis (2001) utilizaram seqüências derivadas de sete fitocistatinas, identificadas no projeto genoma de Arabidopsis.

Foram identificadas vinte e cinco possiveis fitocistatinas de cana-deaçúcar e, uma análise filogenética permitiu agrupar as fitocistatinas em quatro grupos: (i) contendo o consenso $\mathrm{N}$-terminal; (ii) contendo o consenso $\mathrm{N}$-terminal e mais uma extensão C-terminal; (iii) destituído do consenso $\mathrm{N}$-terminal e (iv) destituído do consenso $\mathrm{N}$-terminal e do motivo conservado $\mathrm{QxV} \times \mathrm{G}$ encontrado em todos os membros da superfamília.

$\mathrm{Na}$ maioria dos estudos de resposta ao ferimento, os danos mecânicos são usualmente feitos pelo esmagamento dos tecidos foliares, no entanto, temse observado que danos derivados de insetos podem causar um acúmulo muito 
maior do inibidor de proteinase que o dano mecânico (Walker-Simmons et al., 1984).

Além disso inúmeros estudos indicam que injúria das plantas por insetos resulta em respostas fisiológicas e bioquímicas específicas quando comparadas ao dano mecânico sozinho. O tempo de acúmulo de transcritos de diversos genes induzidos por ferimento é diferente em folhas feridas por insetos e por dano mecânico, segundo Korth \& Dixon (1997).

Esses mesmos pesquisadores observaram que transcritos para os genes do inibidor de proteinase II (Pin II) e do 3-hydroxy-3-methylglutaryl-coenzime A redutase (HMGR) são acumulados mais rapidamente nas folhas de batata (Solanum tuberosum L.) atacadas por lagartas que nas folhas feridas mecanicamente.

Uma grande proporção de eucariotos multicelulares se alimentam de plantas e, uma fonte particularmente de injúria às plantas são os insetos herbívoros. Inevitavelmente, insetos ao se alimentarem causam ferimentos nas plantas mas, pouco é conhecido sobre como as plantas distinguem e respondem às diferentes ameaças impostas pelo dano mecânico e herbivoria (Reymond et al., 2000).

Embora estudos mostrem que alguns genes ou proteinas possam ser ativadas tanto por ferimento mecânico quanto pelo inseto herbivoros (Howe et al., 1996; Stratmann \& Ryan, 1997), outras observações revelaram respostas que são induzidas especificamente ou ativadas mais rapidamente pelo dano dos insetos (Reymond et al., 2000).

Além das diferenças observadas na expressão de diversos genes induzidos por ferimento (Korth \& Dixon, 1997) também ocorre a liberação de voláteis (Paré \& Tumlinson, 1997).

A resposta diferenciada das plantas em função dos insetos levou à descoberta das volicitinas, um fator da saliva dos insetos que induz a produção de voláteis pela planta os quais, atraem insetos predadores dos herbivoros (Alborn et al., 1997; Figura 2). 
Como ocorre com o ferimento mecânico, no qual o jasmonato possui um papel importante na expressão gênica, a habilidade das plantas em produzirem ou percebem membros da familia jasmonato de reguladores é essencial para sua defesa contra insetos (Howe et al., 1996) ou patógenos (McConn et al., 1997).

Reymond et al. (2000) tiveram como objetivo entender melhor como as respostas das plantas ao dano mecânico diferem daquelas causadas por insetos.

A resposta a essa questão é importante devido ao fato dos insetos provavelmente terem desenvolvido estratégias para evitar a ativação da expressão de pelo menos alguns processos de defesa da planta (Reymond et al., 2000).

Estudando a expressão gênica em folhas de Arabidopsis feridas mecanicamente e atacadas por Pieris rapae, utilizando a técnica de microarranjos de cDNA, os mesmos autores observaram uma resposta diferenciada na expressão dos genes. A comparação de dados do ferimento mecânico, desidratação e ataque da lagarta permitiu distinguir diferentes padrões de expressão gênica com um número representativo de genes.

Reymond et al. (2000) observaram ainda que alguns genes foram induzidos em todos os tratamentos, vários foram comuns ao ferimento mecânico e desidratação e outros foram únicos de cada tratamento.

Os resultados obtidos por Reymond et al. (2000) são coerentes com a idéia de que as lagartas, como a Pieris rapae, podem utilizar técnicas de alimentação para minimizar a ativação de genes de defesa da planta hospedeira.

Assim alguns desses genes fornecem uma boa ferramenta para futuras análises de vias de sinalização envolvidas especificamente nas respostas de ferimento mecânico ou danos por insetos.

Vale ressaltar que o gene $H E L$ foi somente induzido pelas lagartas de $P$. rapae. Experimentos com lagartas $P$. brassicae apresentaram resultados 
semelhantes (Reymond et al., 2000), ou seja, novamente HEL foi induzido especificamente pelo inseto.

O gene HEL é sabidamente induzido por patógenos por meio da via dependente do ácido jasmônico (Potter et al., 1993; Thommma et al., 1998) porém, Reymond et al. (2000) mostraram que esse gene também é induzido pelo ataque de insetos.

Portanto, o gene HEL, que talvez seja induzido por um elicitor liberado pelos insetos, fornece um bom marcador para estudos futuros de interação planta-inseto (Reymond et al., 2000).

Por outro lado, muitos genes induziveis não foram afetados pelo ataque da lagarta e outros foram induzidos por ambos os danos, como por exemplo, o gene LOX2 (lipoxigenase).

Todos esses genes estudados são de grande interesse na transformação de plantas visando sua resistência a insetos.

No entanto, é importante ressaltar que a expressão constitutiva destas proteinas pode ser problemática por isso, é necessário o isolamento e clonagem de promotores que sejam induzidos pela herbivoria.

\subsubsection{Vias de sinalização}

O entendimento da interação entre diferentes vias de defesa contra pragas e patógenos é essencial para o desenvolvimento e otimização das estratégias de proteção das culturas (Bruxelles \& Roberts, 2001).

Para Xing \& Jordan (2000) a transdução de sinal é muito mais complexa que um tráfego de mão única pois as vias de transdução são caracterizadas por: elementos agindo positivamente e negativamente; mecanismos de retorno, integração e divergência de sinais; vias simples e paralelas; elementos chave dividindo; e redundância de vias (Figura 3). 


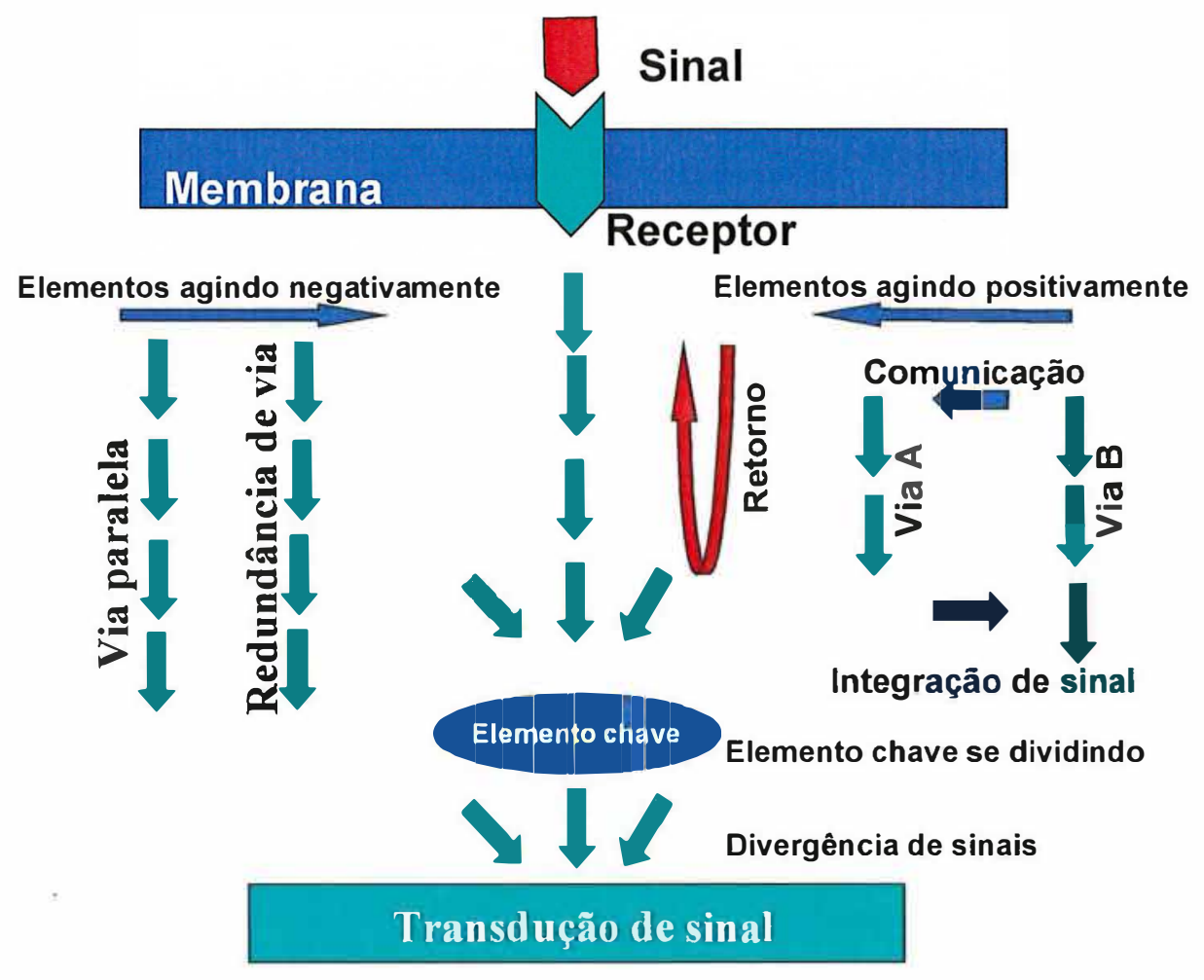

Figura 3 - Controle celular de transdução de sinal

Fonte: Adaptado de Xing \& Jordan (2000)

Por isso, as vias de sinalização envolvendo a ativação de genes ativados pela herbivoria e/ou ferimento têm recebido a atenção de diversos pesquisadores.

Demonstrou-se que a calmodulina e MAP quinase estão envolvidas na via de transdução de sinal de genes codificadores das proteínas induzidas pelo ferimento (PIFs). Embora essa via de transdução de sinal não seja muito bem entendida, muitos trabalhos mostram que a expressão de genes PIFs é regulada positivamente por ácido jasmônico, ácido abscísico, etileno e sistemina (Creelman et al.,1997; Constabel et al., 1998; Pearce et al. 2001; Kessler \& Baldwin, 2002 e Ryan et al., 2002).

No tecido danificado inicia-se uma série de respostas induzidas interrelacionadas por toda a planta ferida, incluindo: 
-eventos localizados que protegem contra invasão de patógenos oportunistas; -produção de proteínas de defesa e metabólitos secundários na folha danificada e em locais distantes;

-produção de sinais voláteis envolvidos na comunicação com outros organismos (Bruxelles \& Roberts, 2001).

Todos esses eventos indicam que um sinal (ou sinais) liberado do local do dano é levado para toda a planta. Esses sinais incluem fragmentos derivados da parede celular da célula, ácido jasmônico, ácido abscísico, potencial elétrico intermediários da via octadenóide, um polipeptídeo de 18 aminoácidos (isolado de folhas de plantas de tomate), denominado sistemina por estar associada com a sinalização sistêmica, e outros polipeptídeos sinais (Ryan \& Pearce, 2001; Ryan et al., 2002).

Em cana-de-açúcar, os mecanismos de defesa da planta induzidos por herbivoria foram analisados a partir da identificação de seqüências expressas de DNA (ESTs) em cana e comparadas com genes previamente descritos em outras plantas como parte do sistema de defesa (Falco et al., 2001).

De acordo com Falco et al. (2001), a cana-de-açúcar apresenta diversas seqüências expressas (EST) codificando proteínas envolvidas na ativação da via octadenóide, normalmente associada com danos provocados pelo ataque de insetos herbivoros ou similares. Essa via é considerada como a principal rota da ativação das proteínas de defesa.

Em Arabidopsis, foi mostrado que muitos genes são ativados por ferimento mecânico e/ou herbivoria, sendo a expressão de muitos destes genes induzida por tratamento com metil jasmonato ou com seu precursor ácido oxofitodienóico. Estes compostos, membros da família jasmonato (Farmer et al., 1998), são essencialmente reguladores in vivo da expressão de genes de defesa (Reymond \& Farmer, 1998).

Outros sinais e estímulos também levam à expressão de genes em tecidos de plantas lesadas embora, a relativa contribuição de moléculas tais 
como etileno (Rojo et al., 1999) e ácido abscísico (Birkenmeier \& Ryan, 1998) e de sinais elétricos (Wildon et al., 1992) ainda não esteja clara.

Segundo León et al. (2001), repostas ao dano mecânico tanto localmente quanto sistêmica envolvem a geração, translocação, percepção e transdução dos sinais do ferimento para ativar a expressão de genes induzidos pelo dano.

Embora, o papel central do ácido jasmônico em respostas de plantas ao ferimento seja bem estabelecido, outros componentes, como o oligopeptídeo sistemina, oligosacarídeos, outros fitohormônios (como ácido abscísico e etileno) e também fatores físicos (pressão hidráulica ou pulsos elétricos) estão sendo propostos a desempenhar papel na sinalização por ferimento (León et al., 2001).

Segundo esses mesmos autores, diferentes vias de transdução de sinais de ferimento dependentes e independentes de ácido jasmônico foram identificados e parcialmente caracterizados. Os componentes dessas vias são na maior parte similares àqueles implicados em outras cascatas de sinalização em eucariotos. Além disso, alguns desses componentes envolvidos na transdução de sinais de ferimento também agem na sinalização de outras respostas de defesa da planta, sugerindo que eventos de comunicação possam regular a ativação temporal e espacial de diferentes defesas.

\subsection{Regulação da expressão gênica}

Promotores, principais responsáveis pela regulação do gene, têm sido isolados, caracterizados e modificados para obter uma expressão forte em tecidos específicos de diferentes plantas com o objetivo de possibilitar a produção de plantas transgênicas que expressam proteinas de defesa e assim aumentar sua resistência a insetos pragas (Panda \& Khush, 1995).

Segundo Rook \& Bevan, (2003), a regulação da expressão gênica representa o alicerce fundamental para o desenvolvimento das plantas em 
respostas aos estímulos ambientais. As regiões regulatórias dos genes são capazes de detectar estes sinais e responderem, ativando ou reprimindo sua expressão. Porém, várias são as formas que a natureza encontrou para regular a expressão gênica. Entretanto, para a maioria dos genes, a regulação transcricional, é de longe, a forma melhor caracterizada.

Para Rombauts et al. (2003), a maioria das plantas codifica um grande número de proteínas que se ligam ao DNA, potencialmente agindo como fatores de transcrição (TFs). Esses fatores de transcrição se ligam ao DNA em elementos regulatórios específicos agindo em cis (CAREs) e orquestrando o início da transcrição, o qual é um dos pontos mais importantes no controle da regulação gênica. Os CAREs são pequenos motivos conservados (5 a 20 nucleotídeos) normalmente encontrados nas proximidades da extremidade $5^{`}$ de genes, a qual é chamada de promotor.

\subsubsection{Estrutura dos promotores de plantas}

Cada órgão da planta expressa um grupo específico de genes para uma função particular, tais como fotossíntese em folha, formação do pigmento nas pétalas, formação de proteína armazenada em sementes e retirada de nutrientes do solo pela raiz. Por outro lado a expressão dos genes requeridos para a fotossíntese é suprimido em outros órgãos além das folhas.

Por serem expostas a vários tipos de estresse ambiental tais como excesso de luz, temperaturas extremas, seca, salinidade, infecção viral ou microbiana, ferimentos físicos e falta de nutrientes, algumas plantas adquiriram um mecanismo, que envolvem a expressão de um grupo de genes de resistência a estresse, para se protegerem das condições desfavoráveis. $A$ expressão desses genes é controlada por promotores específicos a estresse. Fitohormônios e nutrientes também são fatores que controlam a expressão em plantas (Yoshida \& Shinmyo, 2000). 
De acordo com Yoshida \& Shinmyo (2000) um típico core promotor de plantas consiste dos motivos CAAT e TATA, posicionados diversos pares de base antes do local de inicio da transcrição, para reconhecimento da RNA polimerase dependente do DNA.

Promotores específicos a determinados órgãos, tecidos ou condições do ambiente possuem seqüências de DNA específicas, geralmente antes do core promoter, chamados de elementos cis.

Fatores trans (ou fatores transcricionais) ligam-se ao elemento cis e afetam a atividade da polimerase. Dessa forma, múltiplos elementos cis e fatores trans trabalham juntos para induzir a regulação completa da expressão de um gene. Sendo as seqüências de nucleotídeos do elemento cis basicamente as mesmas em todas as células, a regulação específica da expressão do gene é controlada pela presença de um fator trans ativo no órgão ou tecido específico.

O mecanismo de expressão gênica em plantas é extensivamente estudado em genes de defesa para ferimento ou infecção por patógenos, e em genes induzidos por luz.

Ainda não foi identificado um elemento em cis comum à todas as regiōes promotoras. Esse fato, segundo Hehl \& Wingender (2001) é que justifica a crescente utilização da bioinformática no auxílio de análises e buscas por seqüências regulatórias, embora haja a necessidade de experimentação para dar suporte às análises in silico. No entanto, a identificação de promotores e de seus elementos regulatórios é um dos maiores desafios na bioinformática.

Muitas ferramentas estão sendo desenvolvidas para encontrar motivos conservados em grupo de genes e seus ortólogos, entretanto, devido a sua natureza complexa, a sua predição in silico ainda está iniciando-se (Rombauts et al., 2003). 


\subsubsection{Sistema de expressão constitutiva}

Promotores fortes são necessários para uma eficiente expressão do transgene em células vegetais. Uma preocupação principal é assegurar que a produção da proteína seja suficiente para tornar a planta um sistema de produção em larga escala viável. Para alcançar um nível adequado de acúmulo de mRNA para esse propósito, o promotor 35S CaMV (cauliflower mosaic virus) vem sendo usado como um promotor forte e constitutivo para a expressão de genes de outras plantas em muitos tipos de culturas embora, com níveis diferentes de eficiência dependendo da espécie de planta (Yoshida \& Shinmyo, 2000).

O número de promotores de genes que levam a altos níveis de expressão constitutiva de transgene em monocotiledôneas é limitado e, desses promotores disponiveis, alguns dos mais eficientes são restringidos pelos direitos de propriedade intelectual (Wei et al., 1999).

Segundo Panda \& Khush (1995), várias questões são levantadas sobre a estabilidade de genes modificados, tais como o gene $B t$ para resistência a insetos.

Estratégias estão sendo discutidas no que se refere ao desenvolvimento de genes inseticidas em culturas transgênicas, uma vez que a expressão constitutiva de transgene pode exercer grande pressão de seleção sobre a população de insetos.

Porém, a pressão de seleção pode ser minimizada por meio da expressão de genes inseticidas somente em certas partes da planta (tecido específico) ou, em certos estágios de desenvolvimento (especificidade temporal) ou ainda somente em resposta ao ataque de insetos (específico para ferimento).

Um exemplo de resposta específica ao ferimento foi mostrado por PenãCortes et al. 1988, onde o promotor pin-2 não expressa a proteína inseticida em plantas de batata até ela ser ferida mecanicamente. 


\subsubsection{Sistema de expressão induzida}

Para Yoshida \& Shinmyo (2000), embora um promotor constitutivo forte seja útil para a expressão eficiente de um transgene em células vegetais, uma regulação mais precisa da expressão usando promotores induziveis pode ser vantajoso, particularmente, quando a produção da proteína codificada pelo transgene é desfavorável ao crescimento da planta hospedeira.

O sistema de expressão induzida possui duas principais características: -o nível basal de expressão antes da indução deve ser baixo (especialmente importante quando o produto do transgene é tóxico);

-a indução deve aumentar a expressão a um nivel adequado para obter o efeito desejado.

Alguns promotores de plantas, cuja atividade é induzida em resposta a sinais físicos ou químicos, são úteis para o desenvolvimento de sistema de expressão induzida.

As vantagens de substâncias de defesa induziveis para as plantas não é totalmente claro mas, especular-se que muitas espécies de plantas se desenvolveram em ambientes muito hostis onde seus nutrientes eram limitados, dessa forma foi essencial conservar energia.

As defesas induzidas são de particular interesse para a bioquímica e a biologia celular e molecular devido aos desafios para entender os complexos sistemas de sinalização e ao seu potencial para regular geneticamente genes de defesa, para melhorar a produtividade das culturas.

Parte significativa dos promotores usados até o presente momento são patenteados e, portanto, objeto de assinatura de termos de transferência de material biológico, dificultando a utilização comercial das plantas no país.

Por isso, para que se possa utilizar dessa tecnologia com genes de interesse, é imperativo que sejam identificados novos promotores de expressão constitutiva, tecido-específicos e/ou ativados sob determinadas situações de estresse. 
Portanto, na tentativa de desenvolver plantas transgênicas de cana-deaçúcar resistentes ao ataque de insetos, a expressão de proteínas com efeitos antimetabólicos no desenvolvimento e crescimento do inseto necessita o uso de promotores que sejam ativados por herbivoria.

\subsection{Os genes heveína e tipo heveína (HEL)}

\subsubsection{Características gerais da heveína e tipo heveína}

Segundo Broekaert et al. (1990), a heveína é uma proteína de ligação da quitina presente no látex da seringueira.

Essa substância é produzida pelas células altamente especializadas, conhecidas como laticiferas, que sob ferimento liberam seu conteúdo citoplasmático na forma de látex. O local ferido é fechado por meio da coagulação da substância expelida prevenindo assim, a entrada de patógenos no floema Esse processo envolve a quebra de corpos lutóides (organelas de origem vacuolar) e subseqüente interação das proteínas catiônicas liberadas com as partículas de borracha carregadas negativamente. (Broekaert et al., 1990).

Uma das principais proteínas nos corpos lutóides do látex da seringueira é a heveína que é uma proteína pequena de cadeia única que se liga à quitina, com 43 aminoácidos, de forma incomum rica em cisteína e glicina (Broekaert et al. 1990, Koo et al. 1998).

Segundo Koo et al. (1998) a heveína é também uma proteina sintetizada como uma precursora contendo uma seqüência sinal de 17 resíduos seguidos por um domínio heveína de 43 resíduos e uma região carboxil terminal de 144 resíduos. 
De acordo com os mesmos autores, a heveína se liga à quitina e inibe o crescimento de diversos fungos contendo quitina, sugerindo que ela desempenha papel de proteção em locais atacados por fungos.

A heveína também é considerada uma lectina porque apresenta atividade de ligação à carboidratos e, as lectinas (carboidratos ligando proteínas que carregam domínio heveína) têm sido extensivamente estudadas. Todas as proteínas de plantas que possuem pelo menos um domínio heveína são classificadas na superfamília de lectinas de ligação à quitina (Van Damme et al., 1999).

Essa superfamília compreende as merolectinas, que possuem um único domínio heveína ou um domínio heveína fracamente truncado e, as hololectinas que são compostas de subunidades compreendendo 2, 3, 4 ou 7 arranjos seqüenciais de domínio heveína. Além das merolectinas e hololectinas, a família das proteínas que se ligam à quitina também possuem pelo menos três tipos de quimerolectinas (Van Damme et al., 1999).

As lectinas presentes em espécies monocotiledôneas como trigo, cevada e arroz são compostas de quatro domínios do tipo heveína repetidos, enquanto que em dicotiledôneas uma lectina relacionada é composta de dois desses domínios arranjados em seqüência (Neuhaus, 1999).

\subsubsection{Classificação das quitinases}

O desenvolvimento da pesquisa sobre o mecanismo de defesa de plantas tem levado a um rápido e constante interesse nas quitinases, uma vez que foram as primeiras proteínas induzidas por patógenos, cujas funções foram identificadas (Neuhaus, 1999)

As quitinases são enzimas ubíquas de bactérias, fungos, animais e plantas. Elas hidrolizam a ligação $\beta-1,4$ entre resíduos de $\mathrm{N}$-acetilglucosamina da quitina, um polissacarídeo estrutural da parede da célula de muitos fungos e do exoesqueleto de invertebrados. Seu substrato está presente na parede 
celular de muitos fungos, bem como em insetos e nematóides, os quais são os principais patógenos e pragas das culturas (Neuhaus, 1999).

As quitinases já foram purificadas e/ou clonadas de muitas plantas surgindo diversas nomenclaturas para elas: glicosil hidrolases, proteinas relacionadas à patogênese (PR), classes de quitinases e famílias gênicas. Segundo Neuhaus (1999), dentro da nomenclatura PR existe a família PR4 divida em duas classes:

-classe $\mathbf{I}$ - inclui a heveina e as proteínas Win que possuem o domínio de ligação da quitina (CBD);

-classe II - inclui as demais proteínas relacionadas à defesa que difere da classe I por não conter o CBD.

Várias classes de proteínas que se ligam à quitina contêm domínios homólogos à seqüência de heveína.

Quitinases presentes em feijão, tabaco e álamo possuem um domínio do tipo heveína único localizado na região amino-terminal unido a uma porção carboxil terminal não relacionada à terminação carboxil da quitinase. Segundo Broekaert et al. (1990), em plantas de batata dois genes codificando essas proteínas foram induzidos por ferimento.

Neuhaus (1999) clonou de plantas de batata o cDNA codificando proteinas induzidas por ferimento denominadas Win (wound-induced proteins) e encontrou nessas proteínas a presença de um CBD (chitin-binding domain), ou seja, um domínio de ligação à quitina semelhante ao da heveína.

Van Damme et al. (1999) isolaram uma proteina do tipo heveina de frutos de Sambucus nigra, que se liga à quitina $e$, a clonagem do gene correspondente demonstrou que esta proteína é sintetizada como um precursor quimérico.

A comparação dessa seqüência indicou que o domínio $\mathrm{N}$-terminal desse precursor tem alta similaridade da seqüência com o domínio $\mathrm{N}$-terminal das proteínas relacionadas à patogênese PR4 da Classe I, enquanto a parte Cterminal encontrada no precursor está mais relacionada às quitinases Classe V. 
Com base nessas homologias de seqüências, o gene codificando a proteína do tipo heveína analisado pode ser considerado um híbrido entre um gene PR4 e um quitinase Classe V.

\subsubsection{Complexidade da família do gene HEL}

Para determinar a complexidade genética do gene HEL, Potter et al. (1993) analisaram-no por Southern Blot em Arabidopsis usando várias de suas regiões como sonda em altas e baixas estringências.

$\mathrm{Na}$ hibridação de alta estringência, utilizando o clone de CDNA inteiro como sonda, o padrão de bandas obtido revelou um único gene $H E L$.

Já na hibridação de baixa estringência revelou diversas bandas adicionais. Usando fragmentos 5' e 3' do cDNA como sonda foi constatado que as novas bandas eram homólogas à porção 5 ' lectina somente do gene HEL.

Já foi mostrado na literatura que o gene quitinase Classe 1 de Arabidopsis contém um domínio lectina. No entanto, quando um blot idêntico foi sondado com o domínio lectina da quitinase Classe I de Arabidopsis, o padrão de hibridação não correspondeu às bandas não identificadas detectadas pelo domínio lectina do gene HEL em baixa estringência, indicando que o domínio amino-terminal rico em cisteína da quitinase não era suficientemente similar à do HEL para ser detectado pela hibridação.

Genes similares ao HEL, em outras plantas, são membros de famílias multigênicas (Potter et al., 1993).

Segundo esse autor, a família WIN1 e WIN2 de batata contêm pelo menos cinco membros por genoma haplóide e as PR4 de tabaco pertencem à uma família gênica de três a quatro membros.

Outros homólogos do gene HEL devem existir em Arabidopsis, mas a pesquisa feita por Potter e colaboradores (1993) não indicou nenhum proximamente relacionado. 
Devido ao fato do gene HEL aparentemente ser um gene único, representa uma perspectiva interessante para estudos da regulação da expressão dessa classe de genes.

\subsubsection{Possivel papel das proteínas do tipo heveína na defesa contra patógenos}

As plantas usam uma variedade de proteínas pequenas ricas em cisteína e glicina que as protegem da invasão de patógenos como as tioninas e lectinas que pertencem às classes de proteínas antimicrobianas (Koo et al. 1998).

Koo et al. (2002) afirmam que os peptídeos que exibem atividade antimicrobiana produzidos pelas plantas para defesa da infecção de patógenos são pequenos, variando entre 2 a $9 \mathrm{kDa}$ e podem ser divididos em oito grupos, classificados de acordo com a estrutura de suas pontes de dissulfeto e outras características da seqüência de aminoácidos:

1. Tioninas;

2. Defensinas;

3. Proteínas de transferência de lipídios;

4. Peptídeos tipo heveína;

5. Peptídeos tipo nó (knottin-type);

6. Serpenteado (Snakins);

7. Peptídeos antimicrobianos de Zea mays;

8. Peptídeos antimicrobianos de Impatiens balsamina.

De acordo Koo et al. (1998), muitas proteínas que se ligam à quitina contêm um domínio heveína ou uma seqüência homóloga exibindo vários graus de atividades microbianas, particularmente, atividades antifúngicas. Essas proteínas incluem as quitinases, aglutinina do germe do trigo (WGA), cevada germinada, e peptídeos antimicrobianos de Amaranthus caudatus. 
Segundo Lee et al. (2003) a heveína e a tipo heveína são proteinas antimicrobianas de pequeno peso molecular encontras em seringueira (Broekaert et al., 1990), sementes de amarantus (Broekaert et al., 1992) e de Pharbitis nil (Koo et al., 1998), frutas de elderberry (Van Damme et al., 1999), folhas de batata doce (Nielsen et al., 1997), Arabidopsis (Potter et al., 1993) e casca de Eucommia ulmoides (Huang et al., 2002).

Todas essas proteínas são polipeptídeos contendo resíduos de 40-43 aminoácidos e possuem um possível domínio de ligação a quitina rico em cisteína/glicina característico (Lee et al., 2003).

Desta forma é proposto que essas proteinas se liguem a quitina da parede celular e interrompam a sua sintese.

No entanto, de acordo com os mesmos autores, a proteína antimicrobiana do tipo heveína de $P$. nil exibe considerável atividade antifúngica contra um amplo espectro de fungos, incluindo aqueles que não contêm quitina em suas paredes célulares.

De acordo com Koo et al. (1998), não é conhecido o processo pelo qual as proteínas que se ligam à quitina exibem atividades antifúngicas ou antibacterianas em nivel molecular. A ação comum conhecida entre as proteínas heveína, aglutinina de Urtica dioica (UDA) e a tionina seria a de destruir a membrana celular.

Especula-se que as propriedades antifúngicas das proteinas heveina e aglutinina de Urtica dioica (UDA) estão relacionadas ao tamanho de suas moléculas. Essas proteínas são pequenas o bastante para penetrar através da parede celular dos fungos e alcançar a membrana plasmática, onde elas talvez possam ter um efeito nos sítios ativos da moforgênese da parede celular (Koo et al., 1998).

As tioninas, uma outra classe de pequenas proteínas antimicrobianas ricas em cisteína, acredita-se fazer poros nas membranas, os quais podem resultar no rompimento das mesmas e levar o microrganismo a morte (Koo et al., 1998). 
Pesquisa desenvolvida por Potter et al. (1993) utilizou um clone de cDNA de Arabidopsis que codifica uma proteina similar à heveína de ligação à quitina antifúngica do látex da seringueira.

O mRNA dessa proteina do tipo heveina (HEL) foi induzido tanto pela infecção por vírus como por tratamento por etileno. Além disso, a expressão foi moderadamente induzida por tratamento com componentes que induzem resistência, como ácido salicílico.

A seqüência de aminoácidos dessa HEL contém uma possivel seqüência sinal de 21 aminoácidos seguido por um domínio de lectina rico em cisteína de 43 aminoácidos e um domínio carboxi terminal de 129 aminoácidos. Esta proteina é aproximadamente $70 \%$ idêntica à heveina, às proteinas WIN1 e WIN2 da batata induzidas por ferimento e à PR-4, proteína relacionada à patogênese de tabaco.

Potter et al. (1993) apontam três evidências sugerindo que a proteina do tipo heveína produzida pelo gene HEL está envolvida na resposta de Arabidopsis à infecção de patógenos:

- o produto da tradução divide extensa homologia com lectinas antifúngicas conhecidas, em particular a heveina;

-a infecção por patógenos induz o acúmulo de mRNA do tipo heveína no local do ataque e de forma sistêmica;

-o etileno, um indutor de atividades antifúngicas em outras espécies, induz fortemente a expressão da HEL.

Conclui-se, portanto, que o produto do gene HEL pode levar à atividade antimicrobiana e é induzido pelo estímulo fisiológico relacionado à infecção pelo patógeno.

\subsubsection{As proteinas dos genes PR como inseticidas}

Segundo Datta et al. (1999), experimentos com plantas transgênicas contendo genes de quitinase mostraram que não houve efeito significativo 
sobre as pragas do tipo traça do tomate e broca do colmo do arroz. Porém, resultados positivos foram obtidos para o afídio da maçã do tomate (Myzus persicae), Heliothis virescens e Manduca sexta para tabaco.

Os resultados obtidos por Reymond et al. (2000) mostram claramente que muitos genes altamente induzidos por dano mecânico foram menos ou nada induzidos quando a planta foi atacada por Pieris rapae, podendo ser característica vantajosa para os insetos.

Dentre os genes que não foram induzidos pelo ataque de $P$. rapae estão os genes PR e os genes envolvidos na síntese de metabólitos aromáticos. Por outro lado, o gene de defesa $H E L$ foi induzido pela $P$. rapae mas não pelo ferimento mecânico (Reymond et al., 2000).

Segundo Potter et al. (1993), o gene HEL é reconhecidamente ativado por patógenos utilizando a via de sinalização dependente do ácido jasmônico e, Reymond et al. (2000) comprovou que a ativação desse gene também ocorre pelo ataque de inseto (provavelmente induzido por um elicitor liberado do inseto).

Dessa forma o gene HEL proporciona um bom marcador para estudos futuros de interação planta-inseto.

\subsubsection{Regulação transcricional da expressão do gene PR}

A regulação transcricional é uma das áreas mais estudadas na pesquisa dos genes PR e a regulação da expressão desses genes, induzidos por patógenos, freqüentemente ocorre em nivel transcricional (Zhou, 1999).

Por meio de estudos da região promotora, diversos elementos regulatórios cis que mediam a expressão dos genes PR induzidos por patógenos foram identificados: o $\mathrm{W}$-box (consenso TTGACC ou TGAC-[N] $]_{x}$ GTCA); o GCC box (consenso AGCCGCC); a seqüência tipo MRE (consenso $A[A / C] C[A / T] A[A / C] C$ ); o G-box (consenso CACGTG); o elemento responsivel à Acetil Salicilico (SARE, com consenso de TTCGACCTCC); e um elemento cis 
de 11 pares de base mediando a expressão do gene PR2 induzido em salsa (Bohlmann \& Apel, 1987; Gauzing, 1987; Zhou, 1999).

Segundo Zhou (1999), o GCC box e o W-box são amplamente estudados e possuem profunda implicação na regulação do gene PR.

De acordo como esse autor, o GCC box foi originalmente identificado como elemento responsivo ao etileno no promotor de genes PR de tabaco (Zhou, 1999). Mais de vinte genes de plantas foram identificados contendo GCC box, a maior parte destes de solanáceas (Epple et al., 1997)

Porém outros genes responsivos ao etileno que agem no amadurecimento de frutos e senescência das flores aparentemente não contêm - GCC box. Isto mostra que esse motivo está associado com respostas à defesa mediadas pelo etileno (Zhou, 1999).

Outro elemento cis altamente conservado, segundo esse autor, é o W box que está presente nos genes que codificam as proteinas: PR1 (presente em salsa e milho); quitinase Classe I (presente em tabaco); e PR10 (presente em aspargo e batata).

O W box também está presente no promotor de outros genes induzidos por patógenos, tais como glutationa S-transferase de batata e a fitolexina de uva, sugerindo assim um amplo papel desse elemento na expressão dos genes induzidos por patógenos(Gausing, 1987). 


\section{MATERIAL E MÉTODOS}

\subsection{Estudo da expressão gênica em cana-de-açúcar}

3.1.1 Estudo da expressão gênica em cana-de-açúcar por meio da análise assistida por computador

O banco de dados do SUCEST (http://sucest.lad.ic.unicamp.br/en/) é composto por bibliotecas não normalizadas de cDNAs de diferentes tecidos, sendo o número de ESTs de cana-de-açúcar por bibliotecas definido. Uma vez que os eventos de sintese, ligação do cDNA ao vetor e transformação são ao acaso, o número de seqüências expressas (ESTs) de uma dada biblioteca de cDNA pode ser considerada como sendo proporcional à expressão dos mRNAs utilizados como molde para sua síntese.

Assim, uma análise quantitativa e qualitativa da expressão da proteina de defesa nos diferentes tecidos de cana-de-açúcar foi feita in silico seguida de uma correlação entre o número de ESTs de uma proteína em particular e o número total de ESTs de uma biblioteca de cDNA. Os resultados foram plotados em gráficos.

\subsubsection{Análise da expressão gênica por meio da técnica Northern Blot}

A análise da expressão dos genes nas plantas de cana foi realizada por meio da técnica de Northern Blot no Laboratório do Prof. Dr. Paulo Arruda 
(CBMEG/UNICAMP). Dentre os vários protocolos testados obteve-se melhores resultados com o protocolo adaptado de Sambrook et al. (1989), utilizado nesse laboratório.

\subsubsection{Plantas de cana-de-açúcar}

Para os ensaios de indução da expressão de genes por herbivoria foi utilizada a variedade SP80-3280 de cana-de-açúcar fornecida pelo Centro de Tecnologia Copersucar.

\subsubsection{Insetos}

As lagartas de Diatraea saccharalis (Fabricius 1794) utilizadas no experimento foram fornecidas pelo Prof. Dr. José Roberto Postali Parra do Departamento de Entomologia, Fitopatologia e Zoologia Agrícola da Escola Superior de Agricultura "Luiz de Queiroz" - ESALQ/USP e pelo Centro de Tecnologia Copersucar.

Elas foram mantidas em tubos e alimentadas com dieta artificial à base de farelo de soja e germe de trigo (King \& Hartley, 1985) e mantidas a $25^{\circ} \mathrm{C}$, $60 \pm 10 \%$ de umidade e fotoperíodo de $14 / 10$ horas de claro/escuro.

No dia anterior ao início do experimento, as lagartas foram retiradas da dieta artificial e deixadas sem alimento durante toda à noite, nas mesmas condições de umidade, temperatura e luz descritas acima. Esse procedimento foi adotado a fim de se evitar a movimentação das lagartas sobre as plantas ou mesmo a sua fuga, a partir de observações anteriores. 


\subsubsection{Indução da expressão gênica por herbivoria nas plantas de cana- de-açúcar}

Foram utilizados os seguintes genes induzidos por herbivoria, encontrados na literatura:

- Polifenol oxidase - PPO (Constabel et al., 2000);

- Lipoxigenase - LOX2 (Reymond et al., 2000);

- Metalotioneína - MT1 Reymond et al., 2000);

- Proteína do tipo heveína - HEL (Reymond et al., 2000);

- Cistatina - CIS (inibidor de proteinase - PIN2 em Korth \& Dixon, 1997);

- Como controle foi utilizado o gene constitutivo da $\beta$-actina.

Foi realizada uma busca no banco de dados do SUCEST e os clones escolhidos foram solicitados. Os clusters destes genes são apresentados Tabela 1.

Tabela 1. Genes que foram utilizados nos ensaios e seus relativos clusters

\begin{tabular}{lllll}
\hline \multicolumn{1}{c}{ Gene } & \multicolumn{1}{c}{ Cluster } & Acesso & $\begin{array}{c}\text { Score/ } \\
\text { e-value }\end{array}$ & \multicolumn{1}{c}{ organismo } \\
\hline PPO & SCEZLB1007D07.g & gi|2737882 & $1189 / 0.0$ & Saccharum \\
LOX2 & SCEQRT2094C10.g & gi|8515851 & $716 / 0.0$ & Zea mays \\
MTI & SCCCLB1025A03.g & gi|266578 & $82 / 3 \mathrm{e}-15$ & Zea mays \\
HEL & SCVPRT2073C10.g & gi|2119757 & $229 / 2 \mathrm{e}-59$ & Zea mays \\
CIS & SCBGAM1090E08.g & gi|585033 & $104 / 1 \mathrm{e}-21$ & Solanum tuberosum \\
B-ACTINA & SCCCST3C07D05.g & gi|9965319 & $753 / 0.0$ & Setaria italica \\
\hline
\end{tabular}

Os ferimentos nas folhas e colmo das plantas de cana-de-açúcar foram feitos por herbivoria, ou seja, através de um inseto-praga desta cultura.

Inicialmente, vários ensaios foram montados a fim de observar o comportamento das lagartas de Diatraea saccharalis, em diferentes ínstares, nas plantas de cana-de-açúcar bem como a melhor maneira e local de 
posicioná-las na planta para posterior extração de RNA para o estudo da expressão gênica.

As plantas de cana-de-açúcar da variedade SP80-3280, provenientes da Copersucar, com aproximadamente 3 meses após o plantio, foram colocadas em casa de vegetação do Departamento de Genética com temperatura diurna variando de $25-30^{\circ} \mathrm{C}$.

Lagartas de $D$. saccharalis de $4^{\circ}$ instar foram inoculadas nas folhas superiores, próximas à bainha.

A extração de material vegetal foi feita nos seguintes tempos: $0,6,12 \mathrm{e}$ 24 horas depois de colocadas as lagartas. Como controle, foram retirados consecutivamente materiais vegetais de plantas sem a presença de lagartas nesses mesmos tempos. Cada tempo, em cada tratamento, contou com 5 repetições (plantas).

As plantas foram cortadas em seguida, congeladas em nitrogênio líquido e guardadas em freezer $-80^{\circ} \mathrm{C}$ para posterior extração de RNA.

Os procedimentos foram baseados na metodologia descrita por Korth \& Dixon (1997).

\subsubsection{Isolamento do RNA}

Para o isolamento do RNA foi utilizada a região de transição caule-raiz, pois foi o local preferencial de penetração nas plantas (Figura 4).

Os procedimentos de isolamento do RNA total foram baseados no protocolo do reagente ácido guanidínico tiocianato-fenol-clorofórmio (TRIzol ${ }^{\circledR}$, GIBCO-BRL), conforme instruções do fornecedor. 

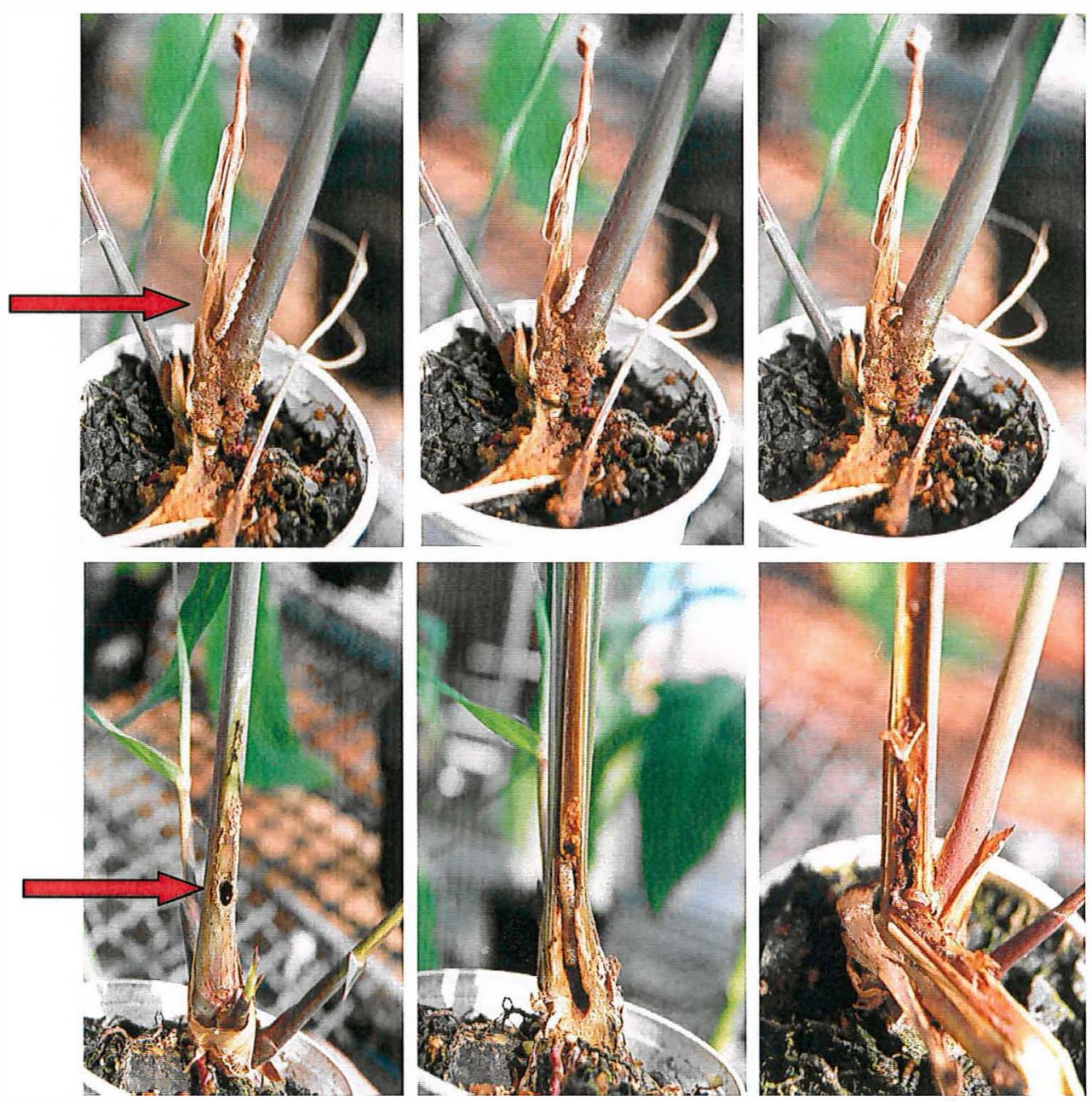

Figura 4 - A seta vermelha está indicando a região da planta utilizada na extração de RNA. Esse é o local onde foram observados os maiores danos causados pelo ataque das lagartas de Diatraea saccharalis às plantas de cana-de-açúcar

\subsubsection{1 Homogeneização}

Foi adicionado $1 \mathrm{~mL}$ de reagente Trizo|ß (Gibco BRL) em $100 \mathrm{mg}$ de folhas de cana-de-açúcar congeladas em nitrogênio líquido. O material foi macerado em cadinho e incubado por 5 minutos a temperatura ambiente. Para reduzir os compostos indesejáveis como polissacarídeos, lipídeos e DNA o homogeneizado foi centrifugado à $12000 \mathrm{~g}$ por 15 minutos, à $4^{\circ} \mathrm{C}$ e o sobrenadante transferido para outro tubo. 


\subsection{Fase de separação}

Foi adicionado ao sobrenadante $0,2 \mathrm{~mL}$ de clorofórmio (puro) em cada tubo. Em seguida esses tubos foram agitados à mão por aproximadamente 15 segundos e incubados por 3 minutos à temperatura ambiente. A seguir, esse homogeneizado foi centrifugado à $12000 \mathrm{~g}$ por 15 minutos à $4^{\circ} \mathrm{C}$. Após a centrifugação, ocorreu a formação de uma fase vermelha no fundo do tubo (fase fenol/clorofórmio), uma interface e uma fase aquosa, que continha o RNA. A fase aquosa foi transferida para um novo tubo.

\subsection{Precipitação}

Para melhorar a qualidade do RNA e diminuir a contaminação com DNA, substituiu-se $0,250 \mathrm{~mL}$ de isopropanol por $0,250 \mathrm{~mL}$ de citrato de sódio $0,8 \mathrm{M}$ em presença de cloreto de sódio 1,2 M, preparado com água tratada com dietil pirocarbonato (DEPC) $0,1 \%(\mathrm{v} / \mathrm{v})$ para cada $1 \mathrm{~mL}$ de Trizol@ utilizado no início. As amostras foram misturadas e incubadas por 10 minutos à temperatura ambiente. Em seguida, foram centrifugadas por $12000 \mathrm{~g}$ por 10 minutos à $4^{\circ} \mathrm{C} \mathrm{e}$ o sobrenadante removido. Após a centrifugação formou-se um precipitado gelatinoso no fundo do tubo.

\subsection{Lavagem do RNA}

O precipitado foi lavado uma vez com $1 \mathrm{~mL}$ de etanol $75 \%$ (v/v) (preparado com água tratada com dietil pirocarbonato $0,1 \% \mathrm{v} / \mathrm{v}$ ). A lavagem foi feita através de agitação no vórtex e em seguida centrifugado por $7500 \mathrm{~g}$ por 5 minutos à $4^{\circ} \mathrm{C}$ e o sobrenadante descartado. 


\subsection{Solubilização do RNA}

O RNA foi seco à vácuo e depois dissolvido em $30 \mu \mathrm{l}$ de água livre de RNAse (tratada com dietil pirocarbonato $0,01 \%(\mathrm{v} / \mathrm{v})$ ), com auxílio da pipeta. As amostras foram incubadas por 10 minutos à $55^{\circ} \mathrm{C}$.

\subsection{Quantificação do RNA total}

A concentração e pureza de RNA foram determinadas por meio da medição da absorbância a $260 \mathrm{~nm}\left(\mathrm{~A}_{260}\right)$ e $280 \mathrm{~nm}\left(\mathrm{~A}_{280}\right)$ em espectrofotômetro. A absorbância lida a $260 \mathrm{~nm}$ mede a concentração de RNA e deve ser maior que 0,15 para assegurar significância. $A$ absorbância de uma unidade a $260 \mathrm{~nm}$ corresponde a $40 \mu \mathrm{g}$ de RNA por $\mathrm{mL}\left(A_{260}=1=40 \mu \mathrm{g} / \mathrm{mL}\right)$. Essa relação é válida para medidas em água, portanto para quantificar o RNA das amostras utilizadas a diluição foi feita em água. $A$ relação entre os valores de absorbância a 260 e $280 \mathrm{~nm}$ fornece uma estimativa da pureza do RNA, a qual pode variar de uma relação de 1,5 a 1,9. Quando as amostras de RNA foram quantificadas para assegurar que as cuvetas estavam livres de RNase, estas foram lavadas com $0,1 \mathrm{M} \mathrm{NaOH}, 1 \mathrm{mM}$ de EDTA, seguida de lavagem com água livre de RNase. Para calibrar o espectrofotômetro foi utilizado o mesmo tampão onde o RNA foi diluído, neste caso água.

\subsection{Integridade do RNA e quantificação}

Para a integridade do RNA as espécies ribossomais relevantes devem aparecer como bandas distintas no gel. Bandas de RNA ribossomal $28 \mathrm{~S}$ e $23 \mathrm{~S}$ devem estar presentes em quantidade aproximadamente duas vezes maior que a dos RNAs $18 \mathrm{~S}$ e 16S. Se as bandas ribossomais não estiverem bem definidas, mas aparecem como um rastro, é provável que as amostras de RNA analisadas tenham sofrido degradação durante sua preparação. 
A integridade e a distribuição por tamanho do RNA total foram checadas por eletroforese. O gel desnaturante para RNA foi composto de $1 \%(p / v)$ agarose, $10 \%(\mathrm{v} / \mathrm{v})$ tampão 10x MOPS pH 7.0 [0,2 M de ácido 3 ( $\mathrm{N}$-morfolino) propanossulfônico (MOPS), $50 \mathrm{mM}$ de acetato de sódio e 0,5 M de ácido etileno diamono tetracético (EDTA) $\mathrm{pH} 8.0$ ], $5 \%(\mathrm{v} / \mathrm{v})$ de formaldeído $37 \%$ e água tratada com $0,1 \%(v / v)$ de dietil pirocarbonato (DEPC).

Durante o tempo de polimerização do gel, as amostras de RNA foram preparadas para a quantificação. Assim, $3 \mu \mathrm{l}$ de cada amostra de RNA foram colocados em $10 \mu \mathrm{l}$ de tampão desnaturante, e esta solução foi aquecida em Banho-Maria a $60^{\circ} \mathrm{C}$ por 10 minutos e, imediatamente incubada em gelo para então ser aplicada no gel. O tampão desnaturante foi composto de $50 \%(v / v)$ de formamida deionizada $[2,5 \%(\mathrm{p} / \mathrm{v})$ de resina de troca iônica mista (AG501-X8) em formamida], $10 \%$ (v/v) de MOPS 10X, 17,5\% (v/v) de formaldeído $37 \%, 8 \%$ (v/v) de brometo de etídio $(5 \mathrm{mg} / \mathrm{mL}), 10 \%$ de tampão de amostra $[0,25 \%(p / v)$ de azul de bromofenol, 0,25\% (p/v) de xileno cianol FF e $40 \%(p / v)$ de sacarose, em água tratada com $0,1 \%(v / v)$ de dietil pirocarbonato (DEPC)], 4,5\% (v/v) de água tratada com $0,1 \%(\mathrm{v} / \mathrm{v})$ de DEPC e armazenado a $-20^{\circ} \mathrm{C}$ até o momento do uso.

Após a aplicação das amostras no gel, adicionou-se tampão MOPS 1x na cuba até que o gel estivesse totalmente submerso. Também foi colocado no gel o marcador de peso molecular 0,24-9,5 kb (Gibco). recebeu o mesmo tratamento térmico das amostras de RNA. Após a eletroforese, o gel foi retirado da cuba, colocado sobre um transluminador UV e fotodocumentado.

Foi feita a quantificação do RNA do gel no aparelho Eagle eye. Um segundo gel foi feito para aferir as concentrações de RNA (para que todos ficassem na mesma concentração). 


\subsection{Armazenamento do RNA}

O RNA total foi dissolvido em água tratada com $0,1 \%$ (v/v) dietil pirocarbonato (DEPC) e armazenado a $-20^{\circ} \mathrm{C}$.

\subsubsection{Manuseio do RNA}

As ribonucleases (RNAses) são muito estáveis e ativam enzimas que geralmente não requerem cofatores para funcionar. Como é difícil inativar as RNAses e apenas pequenas quantidades são suficientes para destruir RNA, não se pode utilizar qualquer plástico ou vidro sem primeiro eliminar possíveis contaminações com estas nucleases. Foi tomado muito cuidado para evitar a introdução por acaso de RNAses dentro das amostras de RNA durante ou após o processo de isolamento.

Com o objetivo de criar e manter um ambiente livre de RNAse, precauções foram tomadas durante o trabalho com o RNA em relação ao uso de recipientes descartáveis e não descartáveis e soluções.

\subsection{Cuidados gerais}

Técnicas apropriadas de assepsia foram usadas durante o trabalho com RNA. Como as mãos e partículas de poeira podem carregar bactérias e fungos e são as fontes mais comuns de contaminação com RNAse, sempre foram utilizadas luvas de látex para o manuseio de reagentes e amostras de RNA. Isto para prevenir contaminação por RNAse da superfície da pele ou da poeira. As luvas foram trocadas freqüentemente e os tubos mantidos fechados.

\subsection{Plásticos}

Foram utilizados tubos de polipropileno descartáveis novos e estéreis. Estes tubos por serem, geralmente, livres de RNA não requerem tratamento para inativar RNAses. Já materiais plásticos que não eram descartáveis foram 
tratados antes de usar para assegurar que estivessem livres de RNAse. Estes materiais foram tratados enxaguando-os com 0,1 M NaOH, $1 \mathrm{mM}$ EDTA e por último com água livre de RNAse.

\subsection{Vidraria}

Os vidros também foram tratados antes de serem usados para assegurar que estivessem livres de RNAses. Os vidros usados para trabalhar com RNA foram lavados com detergente, enxaguados e deixados na estufa a $180^{\circ} \mathrm{C}$ durante a noite antes de serem utilizados.

\subsubsection{4 cubas de eletroforese}

As cubas de eletroforese foram lavadas com uma solução de detergente $0,5 \%$ dodecil sulfato de sódio (SDS), enxaguados com água, secos com metanol e então completados com uma solução $10 \%(v / v) \mathrm{H}_{2} \mathrm{O}_{2}$. Após 10 minutos à temperatura ambiente, as cubas de eletroforese foram enxaguadas com água livre de RNAse.

\subsubsection{5 soluções}

A água e as soluções utilizadas nos ensaios com RNA foram tratadas com dietil pirocarbonato (DEPC). Para o tratamento foi adicionado $0,1 \%(\mathrm{v} / \mathrm{v})$ de DEPC aos tubos e esses mantidos sob agitação por 12 horas a $37^{\circ} \mathrm{C}$ e posteriormente autoclavados para remover os traços de DEPC.

\subsubsection{Confirmação do cDNA recebido}

Inicialmente os clones contendo a seqüência do cDNA correspondente à proteina de interesse, obtidos junto ao banco de dados do projeto SUCEST cana-de-açúcar, foram confirmados por seqüenciamento. 


\subsubsection{Isolamento do plasmídeo}

Os plasmídeos pSport1 (4110 pares de base) contendo os cDNAs foram isolados por meio de uma minipreparação utilizando o método de lise alcalina, modificado de Sambrook \& Russel (2001), ou seja, uma colônia bacteriana foi crescida em $3 \mathrm{~mL}$ de meio Luria-Bertani (LB) líquido composto de $1 \%(\mathrm{p} / \mathrm{v})$ de bacto-triptona, $0,5 \%(\mathrm{p} / \mathrm{v})$ de extrato de levedo, $1 \%(\mathrm{p} / \mathrm{v})$ de $\mathrm{NaCl} \mathrm{pH} 7,5$, acrescido do antibiótico ampicilina (100 mg/L) por 14 horas, sob agitação de 180 rotações por minuto, a $37^{\circ} \mathrm{C}$.

As culturas bacterianas foram transferidas para tubos de $1,5 \mathrm{~mL} e$ centrifugadas por 30 segundos a $20.000 \mathrm{~g}$ à temperatura ambiente (para formar o precipitado). O sobrenadante foi removido e o precipitado ressuspendido em $100 \mu \mathrm{L}$ da solução I gelada [50 mM glicose, $25 \mathrm{mM}$ Tris- $\mathrm{HCl}$ pH 8,0 e $10 \mathrm{mM}$ EDTA] e deixado em temperatura ambiente por 20 minutos.

Em seguida, foram adicionados e misturados nos tubos $200 \mu \mathrm{L}$ da solução II [0,2M NaOH e 1\% dodecil sulfato de sódio (SDS)] e incubados por 10 minutos em gelo.

Completado esse período, foram adicionados $150 \mu \mathrm{L}$ da solução III (3M KOAc pH 5,5), o conteúdo foi misturado por inversão do tubo e centrifugado por 15 minutos a $20.000 \mathrm{~g}$.

Cerca de $400 \mu$ do sobrenadante foram transferidos para um novo tubo de $1,5 \mathrm{~mL}$ (o precipitado foi descartado). O volume de $400 \mu \mathrm{l}$ de clorofórmio saturado foi adicionado e misturado por inversão dos tubos e a seguir centrifugado por 5 minutos, $20.000 \mathrm{~g}$ à temperatura ambiente.

A fase aquosa (a superior) foi transferida para um novo tubo onde foram adicionados $400 \mu \mathrm{L}$ de fenol equilibrado. A amostra foi misturada por inversão e centrifugada por 5 minutos, $20.000 \mathrm{~g}$, à temperatura ambiente. Novamente a fase aquosa foi transferida para um novo tubo e foi acrescentado $1 \mathrm{~mL}$ de etanol absoluto $-20^{\circ} \mathrm{C}$. A amostra após misturada e incubada por 10 minutos a $20^{\circ} \mathrm{C}$ foi centrifugada por 10 minutos a $20.000 \mathrm{~g}$. O sobrenadante foi removido e 
o precipitado seco e ressuspendido em $100 \mu$ de água deionizada estéril. Novamente foi adicionado $1 \mathrm{~mL}$ de etanol absoluto $-20^{\circ} \mathrm{C}$ e a amostra deixada a $-20{ }^{\circ} \mathrm{C}$ por 10 minutos e depois centrifugada por 10 minutos a $20.000 \mathrm{~g}$. $\mathrm{O}$ sobrenadante foi removido e o precipitado seco e ressuspendido em $20 \mu \mathrm{L}$ de água deionizada estéril. Foi adicionado $1,0 \mu \mathrm{l}$ de RNAse $(10 \mu \mathrm{g} / \mu \mathrm{l})$ aos tubos e incubados a $37^{\circ} \mathrm{C}$ por 1 hora.

O DNA extraído foi avaliado e quantificado, após a eletroforese, em gel de $1 \%(p / v)$ agarose com tampão de corrida TBE 0,5x (45 mM Tris- $\mathrm{HCl}$ e $1 \mathrm{mM}$ EDTA) e coloração com brometo de etídeo.

\subsubsection{Seqüenciamento dos cDNAs}

Os clones foram enviados para seqüenciamento automático (seqüenciador de DNA ABI PRISM 377) do Laboratório de Entomologia, Fitopatologia e Zoologia Agrícola da ESALQ, sob a coordenação do Prof. Dr. Luiz Eduardo Aranha Camargo.

A reação de seqüenciamento foi realizada usando-se os procedimentos descritos no manual do kit $A B I P R I S M^{\circledast}$ Big Dye ${ }^{T M}$ terminator cycle sequencing ready reaction kits. Seguindo esse protocolo, em tubos de $0,2 \mathrm{~mL}$ foram adicionados $2 \mu \mathrm{L}$ de mix Big Dye [que contém dNTPs (deoxiribonucleotídeo trifosfatos), terminadores ddNTPs (di-deoxiribonucleotídeo trifosfatos) associados à substâncias fluorescentes e AmpliTaq DNA polimerase, FS], 3 picomoles de iniciadores, $10,5 \mu \mathrm{L}$ de água deoinizada estéril, $6 \mu \mathrm{L}$ de tampão Tris-HCl pH 9,0 contendo cloreto de magnésio e 0,5 $\mu \mathrm{L}$ de DNA plasmidial (200500ng). A seguinte reação de PCR foi utilizada:

- $96^{\circ} \mathrm{C}$ por 2 minutos

- $\quad 96^{\circ} \mathrm{C}$ por 20 segundos

- $\quad 50^{\circ} \mathrm{C}$ por 10 segundos

- $60^{\circ} \mathrm{C}$ por 4 minutos

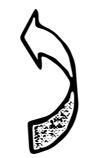
25 ciclos

- $\quad 72^{\circ} \mathrm{C}$ por 7 minutos 
Após a reação de amplificação, as amostras foram transferidas para tubos de $0,65 \mathrm{~mL}$ e adicionada uma solução contendo $20 \mu \mathrm{L}$ de água estéril + $60 \mu \mathrm{L}$ de isopropanol. Essa mistura foi deixada à temperatura ambiente por 15 minutos e centrifugada em uma microcentrífuga de bancada (velocidade máxima) por 20 minutos. O sobrenadante foi cuidadosamente descartado e 0 precipitado lavado com $250 \mu \mathrm{L}$ de etanol $70 \%(\mathrm{v} / \mathrm{v})$.

Logo após os tubos foram por mais 15 minutos sob as mesmas condições anteriores e o sobrenadante foi novamente descartado. Os tubos, com as tampas abertas, foram colocados por 1 minuto em termociclador, previamente aquecido à $90^{\circ} \mathrm{C}$ para a completa evaporação da água das amostras.

No laboratório onde foi realizado o seqüenciamento, as amostras foram ressuspendidas em $4 \mu \mathrm{L}$ de tampão contendo 5 partes de formamida e 1 parte de tampão de carregamento $(0,25 \%(\mathrm{p} / \mathrm{v})$ azul de bromofenol, $0,25 \%(\mathrm{p} / \mathrm{v})$ xileno cianol e $40 \%$ (p/v) sacarose). O DNA foi desnaturado à $98^{\circ} \mathrm{C}$ por 2 minutos e 1 $\mu \mathrm{L}$ de cada amostra foi aplicado no gel.

As colônias, com a seqüência desejada, foram repicadas e estocadas em glicerol a $-80^{\circ} \mathrm{C}$.

Para o clone HEL foi necessário a transformação da bactéria para posteriormente fazer as extrações dos plasmídeos. O DNA liofilizado foi reconstituído em $7 \mu$ de água deionizada estéril e utilizado para transformação das bactérias.

\subsection{Células competentes}

Uma colônia bactérias foi isolada inoculada em $2 \mathrm{~mL}$ do meio líquido Luria-Bertani (LB). As células foram incubadas sob agitação a $37^{\circ} \mathrm{C}$ por 16 horas e, após esse período, $500 \mu$ dessa cultura foram transferidos para um Erlenmeyer estéril de $250 \mathrm{~mL}$ contendo $50 \mathrm{~mL}$ do meio LB. 
O frasco foi mantido a $37^{\circ} \mathrm{C}$ sob agitação (aproximadamente $2-3$ horas) até atingir a fase de crescimento exponencial ( $D O=0,5$ densidade ótica, $\lambda 600 \mathrm{~nm})$.

A cultura foi então centrifugada a $4.000 \mathrm{~g}$, durante 3 minutos, a $4^{\circ} \mathrm{C}$ e 0 sobrenadante descartado. O precipitado foi ressuspendido em $50 \mathrm{mM}$ de $\mathrm{CaCl}_{2}$ gelado e incubado por 30 minutos no gelo. Em seguida o tubo foi novamente centrifugado a $4.000 \mathrm{~g}$, durante 3 minutos, a $4^{\circ} \mathrm{C}$ e o sobrenadante descartado. $O$ precipitado foi ressuspendido em $2,5 \mathrm{~mL}$ de $50 \mathrm{mM} \mathrm{CaCl}_{2}$ gelado.

\subsubsection{2 transformação bacteriana (Escherichia coli)}

O DNA plasmidial foi misturado cuidadosamente nos tubos de $1,5 \mathrm{~mL}$ contendo as células bacterianas competentes e esses tubos foram incubados no gelo durante 30 minutos.

Em seguida, foi dado o choque térmico colocando o tubo rapidamente em um Banho-Maria a $42{ }^{\circ} \mathrm{C}$ durante 2 minutos, e logo após rapidamente no gelo.

Na seqüência, foi adicionado $1 \mathrm{~mL}$ de meio Luria-Bertani (LB) estéril a cada um desses tubos que foram transferidos para um Banho-Maria a $37^{\circ} \mathrm{C}$, durante 1 hora.

As células foram então sedimentadas por meio de centrifugação a 3000 g por 3 minutos. Aproximadamente $800 \mu l$ do meio foram eliminados, as células ressuspendidas no meio LB restante e plaqueadas em placas de Petri contendo o meio de cultura LB sólido acrescido do antibiótico ampicilina (100 mg/L), e mantidas a $37^{\circ} \mathrm{C}$ durante 16 horas. 
3.1.2.9 Preparo das sondas para análise da expressão gênica por meio da técnica, de Northern Blot.

As sondas foram preparadas a partir da digestão do produto da minipreparação, pelo método da lise alcalina (Sambrook \& Russel, 2001), pelas enzimas EcoRI e BamHI (Invitrogen).

As enzimas foram escolhidas baseando-se no mapa de restrição do plasmídeo pSport1 utilizado pelo SUCEST.

A purificação do DNA do gel de agarose foi feita utilizando-se o seguinte protocolo:

Tubos de $0,65 \mathrm{~mL}$ foram perfurados na base com auxilio de uma agulha quente e no fundo foi colocada lã de vidro.

Esses tubos foram colocados dentro de outros de 1,5 mL. As bandas de interesse retiradas do gel, utilizando-se um bisturi, foram colocadas dentro dos tubos de $0,65 \mathrm{~mL}$ e deixadas durante a noite a $-20^{\circ} \mathrm{C}$.

No dia seguinte os tubos foram centrifugados a $4.000 \mathrm{~g}$ por 10 minutos a temperatura ambiente. Esse procedimento permitiu separar a solução contendo o DNA da matriz de agarose. O DNA foi utilizado para o preparo de sondas para a técnica de Northern Blot.

A purificação dos fragmentos de DNA em géis de agarose foi realizada também com auxílio do kit QIAEX /| Gel Extraction (Qiagen), conforme recomendações do fabricante.

\subsubsection{Transferência e fixação de RNA na membrana}

Antes de montar o aparato de transferência, o gel foi tratado com uma solução SSC 10x [ $3 \mathrm{M} \mathrm{NaCl}, 0,3 \mathrm{M}$ citrato de sódio], por 2 vezes com o intervalo de 15 minutos sob agitação, para remoção do formaldeído.

Para a montagem do aparato de transferência, foram colocadas folhas de papel Whatman 3 MM embebidas em solução SSC 10x sobre o aparato, evitando-se a formação de bolhas, e nas bordas, foi colocado parafilme. 
O gel foi colocado com a face superior invertida sobre o papel. Sobre o gel colocou-se a membrana Hybond-N+ (Amersham Pharmacia Biotech), umedecida por 5 minutos em solução SSC 10x. As bolhas foram removidas com o auxilio de um bastão de vidro e um pequeno corte foi feito para marcar um lado da membrana. Em seguida foram colocadas duas folhas de papel Whatman $3 \mathrm{MM}$ pré-umedecidas com tampão SSC 10x tomando-se o cuidado de não deixar bolhas. Uma camada de papel-toalha foi justaposta com aproximadamente $5 \mathrm{~cm}$ de altura. Para homogeneizar a pressão sobre 0 sistema, foi colocada uma placa de vidro e, sobre esta, um peso de aproximadamente $0,5 \mathrm{Kg}$ (Figura 5). O tempo de transferência foi de 12 a 16 horas (durante toda a noite) com SSC 10x. Após esse procedimento, o sistema foi desfeito e marcado com lápis na membrana o lugar das canaletas do gel. Em seguida, a membrana foi retirada com uma pinça e colocada em estufa a $80^{\circ} \mathrm{C}$ durante 2 horas. Quando não utilizada imediatamente, foi armazenada em temperatura ambiente envolvida por papel de geminação.

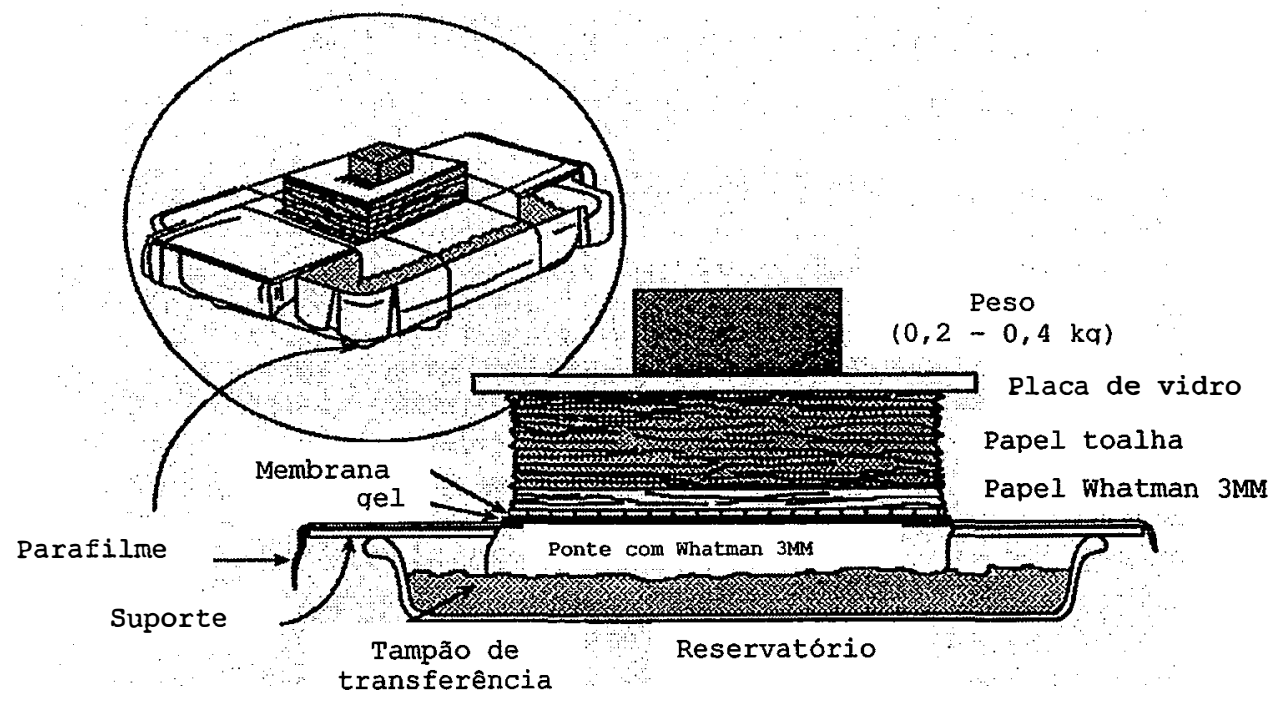

Figura 5 - Esquema ilustrativos do procedimento de transferência do RNA do gel para a membrana

Fonte: Adaptado de Ausubel et al. (1994) 


\subsubsection{Marcação da sonda}

A marcação da sonda foi realizada utilizando o kit da Amersham Pharmacia Biotech denominado Ready-To-Go ${ }^{T M}$ DNA Labelling Beads (-dCTP).

O DNA na concentração de $10 \mathrm{ng} / \mu \mathrm{l}$ foi denaturado a $95^{\circ} \mathrm{C}$ por 10 minutos. Foram acrescentados $45 \mu \mathrm{l}$ de amostra no tubo do kit Ready-To-Go (o pellet foi dissolvido )e, em seguida, foram acrescentados $4 \mu \mathrm{lde}\left[\alpha-{ }^{32} \mathrm{P}\right] \mathrm{dCTP}$ em cada tubo onde permaneceram por 30 minutos a $37^{\circ} \mathrm{C}$. Posteriormente, as amostras foram purificadas nas micro-colunas ProbeQuant G-50 (Amersham Pharmacia).

Para a purificação com colunas ProbeQuant G-50 agitou-se a coluna no vórtex até que a resina ficasse bem homogênea. Em seguida, a tampa foi ligeiramente aberta (para não formar vácuo) e a base da coluna foi destacada.

Posteriormente a coluna foi colocada sobre um tubo de $1,5 \mathrm{~mL}$, centrifugada por 1 minuto a $735 \mathrm{~g}$ e transferida para outro tubo de $1,5 \mathrm{~mL}$, previamente rotulado. A sonda foi adicionada no centro da resina e centrifugada por 2 minutos a $735 \mathrm{~g}$. A solução contendo a sonda foi transferida para um novo tubo de $1,5 \mathrm{~mL}$.

\subsubsection{Pré-hibridização}

As membranas contendo RNA foram umedecidas em solução 2x SSC e, posteriormente, transferidas para tubos de hibridização evitando-se dobrar a membrana.

Inicialmente foi feita a pré-hibridização cuja solução [50\% (v/v) formamida deionizada, 5x SSC (20x), 5x Denhardt (100x), 50 mM fosfato de sódio pH 6,8, $1 \%$ dodecil sulfato de sódio (SDS), e por último $100 \mu \mathrm{g} / \mathrm{mL}$ de DNA de esperma de salmão (previamente denaturado a $94^{\circ} \mathrm{C}$ por 10 minutos e transferido para o gelo)] foi pré-aquecida a $42^{\circ} \mathrm{C}$. Esse procedimento foi efetuado por 4 horas a $42^{\circ} \mathrm{C}$. 


\subsubsection{Hibridização}

Para a hibridização foi preparada uma solução de hibridização [50\% (v/v) formamida deionizada, $5 x$ SSC, $20 \mathrm{mM}$ fosfato de sódio $\mathrm{pH} 6,8,1 \%$ dodecil sulfato de sódio (SDS), $5 \%$ sulfato de dextran]. Foram utilizados $10 \mathrm{~mL}$ da solução de hibridização para tubos grandes e $5 \mathrm{~mL}$ para tubos pequenos e préaquecidos a $42^{\circ} \mathrm{C}$ em tubos de $15 \mathrm{~mL}$ (Falcon) devidamente rotulados (data, sonda, usuário).

As sondas foram denaturadas à $100^{\circ} \mathrm{C}$ durante $5-7$ minutos e colocadas em gelo. Após 1-2 minutos, foram centrifugadas brevemente em temperatura ambiente e colocadas novamente no gelo. A seguir foram adicionadas em tubos de $15 \mathrm{~mL}$ contendo a solução de hibridização e depois de misturadas foram transferidas para os tubos de hibridização. Utilizou-se $10^{7}-10^{8} \mathrm{cpm} / \mathrm{mL}$ de solução.

Após incubação a $42^{\circ} \mathrm{C}$ por aproximadamente 18 horas (durante toda a noite), as membranas foram lavadas com soluçōes contendo SSC e dodecil sulfato de sódio (SDS) (aproximadamente $1 \mathrm{~mL} / \mathrm{cm}^{2}$ de membrana) da seguinte forma:

- 4 vezes à temperatura ambiente (agitação suave) de 10 minutos cada com $2 x$ SSC e $0,05 \%$ SDS;

- 2 vezes a $50^{\circ} \mathrm{C}$ (agitação suave) de 10 minutos cada com $0,1 \times$ SSC e $0,1 \%$ dodecil sulfato de sódio (SDS).

As membranas foram seladas e expostas em cassetes do equipamento Phosphorimager durante 1-2 dias. As imagens digitalizadas dos sinais obtidos pelo Northem Blot foram quantificadas utilizando o software Image Gauge (Fujifilm).

$\mathrm{Na}$ técnica de Northem Blot também foi utilizada, algumas vezes, a solução pronta denominada ExpressHyb ${ }^{T M}$ Hybridization Solution da Clontech. Para a pré-hibridização usou-se $10 \mathrm{~mL}$ dessa solução para os tubos grandes e $5 \mathrm{~mL}$ para os tubos pequenos e a seguir deixados a $68^{\circ} \mathrm{C}$ por 1 hora. $\mathrm{Na}$ 
hibridização foi trocada esta solução por igual volume da mesma acrescida da sonda marcada com $\left[\alpha{ }^{32} P\right] d C T P$ e incubou-se por 2 horas no forno de hibridização a $68^{\circ} \mathrm{C}$.

Em seguida fez-se uma primeira lavagem das membranas a temperatura ambiente [SSC 2x; dodecil sulfato de sódio (SDS) 0,05\% - 4 vezes de 10 minutos cada] e uma segunda a $50{ }^{\circ} \mathrm{C}$ [SSC $0,1 \mathrm{x}$; dodecil sulfato de sódio (SDS) $0,1 \%$ - 2 vezes de 10 minutos cada]. As membranas foram expostas e analisadas da mesma maneira descrita acima.

3.2 Identificação e caracterização de promotores de genes de cana-deaçúcar induzidos por herbivoria

\subsubsection{Extração de DNA}

Para extração de DNA a ser usado na técnica PCR-TAIL utilizaram-se folhas jovens de plantas de cana-de-açúcar da variedade SP80-3280 provenientes da Copersucar, com aproximadamente 3 meses após o plantio e que foram armazenadas em freezer $-70^{\circ} \mathrm{C}$.

Para o sucesso da técnica PCR-TAIL o isolamento e purificação de DNA são etapas bastante importantes, pois, requer que este esteja livre de polissacarídeos, substâncias fenólicas e compostos secundários. Optou-se então, por utilizar o método de extração baseado no uso do detergente CTAB adaptado de Brasileiro et al. (1998).

O DNA das plantas analisadas foi extraído pelo método CTAB (brometo de cetiltrimetilamônio), conforme descrito por Brasileiro \& Carneiro (1998), com pequenas modificações. Tecido vegetal fresco (100 $\mathrm{g}$ de folhas de cana-deaçúcar) foi macerado em nitrogênio líquido, com um almofariz, até a obtenção de um pó fino, que foi transferido rapidamente para um tubo de $1,5 \mathrm{~mL}$ 
contendo $500 \mu \mathrm{l}$ de tampão CTAB [CTAB 2\% (p/v); NaCl 1,4 M; Tris-HCl 100 $\mathrm{mM}, \mathrm{pH} 8,0$; EDTA $20 \mathrm{mM} ; \beta$-mercaptoetanol 0,2\% (v/v)] pré-aquecido a $65^{\circ} \mathrm{C}$.

Essa solução foi incubada a $65^{\circ} \mathrm{C}$ por 30 minutos, agitando-se a cada 10 minutos. Foram adicionados $500 \mu \mathrm{l}$ de uma solução $50 \%$ clorofórmio:álcool isoamílico (24:1) (v/v) e agitada por 10 minutos.

A seguir, centrifugou-se a amostra por 10 minutos a $5.000 \mathrm{~g}$ e a fase aquosa (fase superior) foi transferida para novo tubo e repetiu-se a extração com clorofórmio:álcool isoamílico (24:1) (v/v) e a centrifugação. Foram adicionados $180 \mu \mathrm{l}$ de isopropanol gelado à amostra e o volume misturado várias vezes por inversão do tudo.

O DNA foi recuperado com auxílio de uma ponteira e lavado com $200 \mu \mathrm{l}$ de etanol $70 \%$ (v/v) e centrifugado por 3 minutos, a 10.000g.

O precipitado foi secado com o tubo invertido em papel toalha e em seguida dissolvido em $50 \mu$ de água deionizada estéril e incubado a $4^{\circ} \mathrm{C}$ por meia hora.

Esse DNA foi utilizado nas reações de PCR-TAIL.

\subsubsection{Técnica PCR-TAlL (thermal asymmetric interlaced)}

\subsubsection{Primeira etapa}

Como primeira etapa dessa técnica e tomando como base os resultados de indução gênica obtidos por meio da técnica Northern Blot, foram escolhidos dois genes em estudo, induzidos por herbivoria, para a identificação e caracterização da região promotora.

Para clonagem da região promotora dos genes induzidos por herbivoria optou-se pela técnica conhecida como PCR-TAIL (thermal asymmetric interlaced PCR) desenvolvida por Liu \& Whittier em 1995.

Essa técnica consiste em utilizar inciadores específicos em combinação com iniciadores curtos, degenerados e de seqüências arbitrárias. 
Um programa de PCR bastante elaborado, composto de superciclos contendo um ciclo de baixa estringência e dois de alta estringência, permite que apenas os fragmentos específicos à seqüência sejam exponencialmente amplificados (Figuras 6 e 7 ).
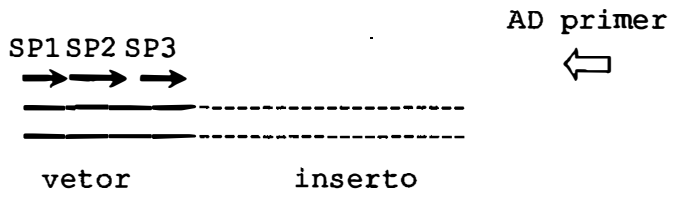

(A) PCR primário com SPI e AD

5 ciclos de alta estringência

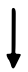

1 ciclo de baixa estringência

$\downarrow$

10 ciclos de estringência reduzida

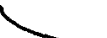

1 ciclo de estringência reduzida

(simetria térmica)

Ciclos do PCR TAIL

(12 super ciclos)

2 ciclos de alta estringência

(assimetria térmica)

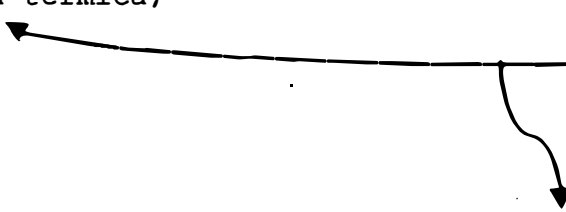

produto específico

(tipo I)

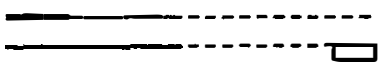

Al to ou médio

(detectável ou indetectável) produto nåo específico

(tipo II)

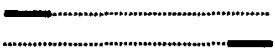

Alto

(detectável) produto não específico

(tipo III)

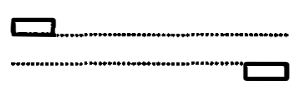

Baixo

(indetectável)

do

Figura 6 - Procedimentos da técnica PCR-TAlL primário

Fonte: Adaptado de Liu \& Whittier, 1995 
(B) PCR secundário com SP2 e AD (10 super ciclos)

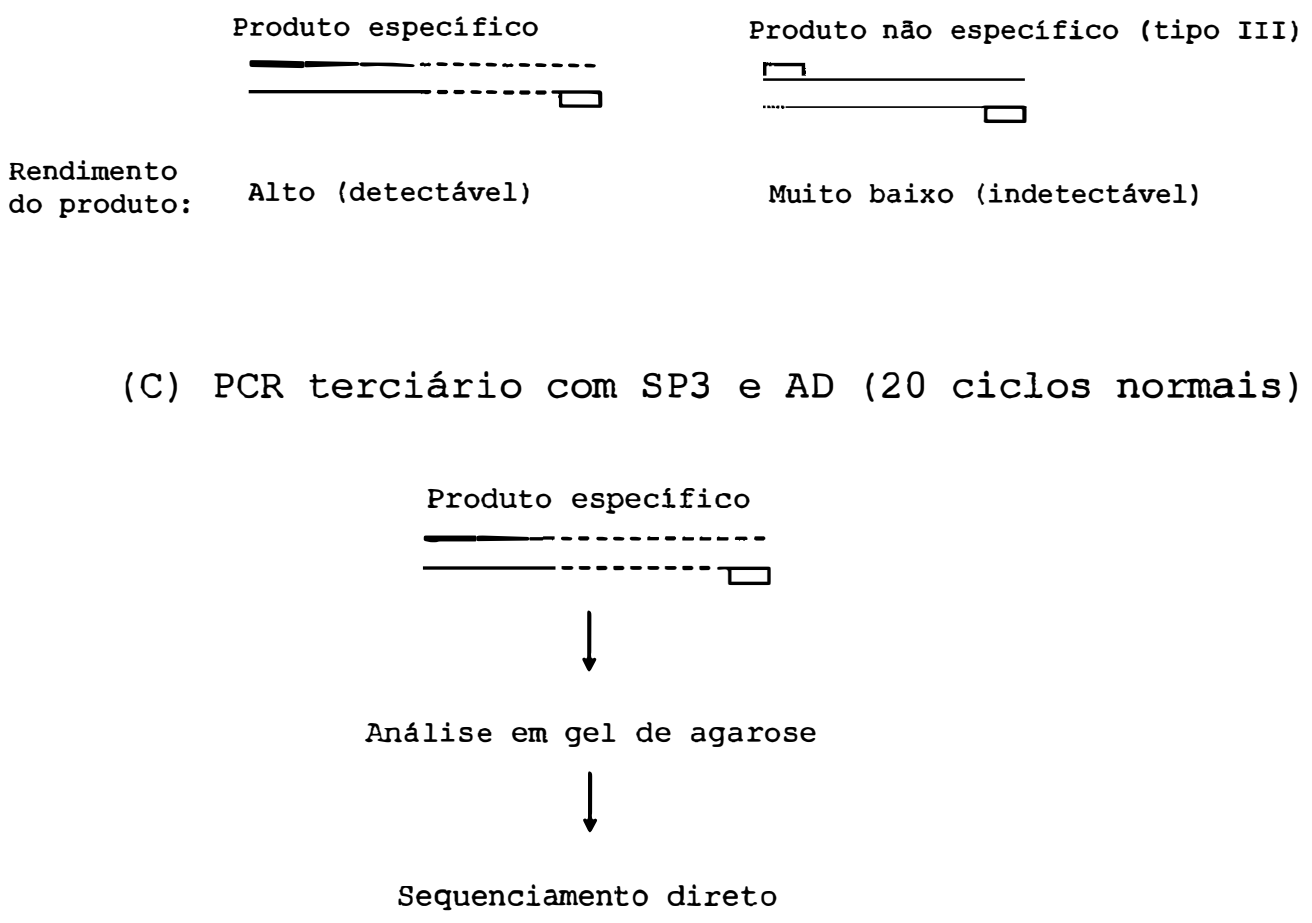

Figura 7 - Procedimentos da técnica PCR-TAIL secundário e terciário Fonte: Adaptado de Liu \& Whittier, 1995

Para clonar a região promotora do gene utilizando-se essa técnica, 7 iniciadores arbitrários e degenerados e 5 iniciadores que se anelavam especificamente na região 5' dos genes HEL e PPO, foram desenhados baseando-se nos procedimentos descritos no artigo original. Os iniciadores arbitrários e específicos são:

Iniciadores específicos para HEL (Figura 8):

HEL5: 5' CCTAACGTGACGCAGACCAA 3'

HEL4: 5' CGTCAGTTGCCTCTTACTGT 3'

HEL3: 5' GCCGCCCGTCCTCCGGAGAT 3'

HEL2: 5' GGCCACCACCACCAGCGCCT 3'

HEL 1: 5' GCCACCGCGCACAGCACGCC 3' 
5 ' caggtcgacccacgcgtccgATTCGTCACTTGGTCTGCGTCACGTTAGGAGCGGCTC

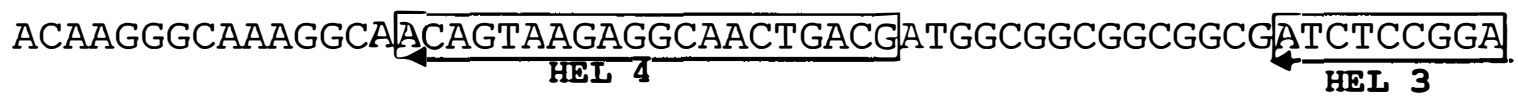
GGACGGGCGGC]GCE

HEL 1

TGGCGGCGGCGCAGCAGGCGTCCAACGTGCGGGCGACGTACCACTACTACAACCCGCAG

CAGAACGGGTGGAACCTCAACGCCGTCAGCGCCTACTGCTCCACGTGGGACGCCGACAA GCCGCTGTCGTGGCGCCAGAAGTACGGCTGGACGGCCTTCTGCGGGCCCGCCGGGCAAA AGGGCCAGGCCGCCTGCGGCAAGTGCATCCGGGTGACGAACCGTGCGACGGGCGCGTCC ATCGTGGCGAGGATCGTGGACCAGTGCAGCAACGGCGGGCTGGACCTGGACTACGAGAC GGTGTTCAAGAAGATCGACACCAACGGGCAGGGCTACCAGATGGGACACCTCAACGTCG aCtAcCagtTCGTCGCCTGCTGATCACTACActtcacCTACTCAAGTACTACTACtgtt tGTAATAATAaGCTATGCATGATGCATGCATGcgTGATCGATGaaTAAACGGATGgaat atatatagctgccagcaactgtacgt $3^{\prime}$

Figura 8 - Locais onde foram desenhados os iniciadores especificos para 0 gene HEL estão em destaque

Iniciadores específicos para PPO (Figura 9):

PPO5: 5' CCATGCCGGCCGGCGCGTCC 3'

PPO4: 5' GGGTTGGCAAAGGCTTCCTT 3'

PPO3: 5' CGCGTTGAGGTTCGCCGTGT 3'

PPO2: 5' GCTGAGGTAGTCTAGGTCGA 3'

PPO1: 5' GGGCTTCGCATCCCTGTGGC 3' 
5 ' CTG GGACGCGCCGGCCGGCATGGTGGTACCGGCTCTCTTCAAGGAAGCCTTTGCCAA PPO 5 CCCGCTGTACGACCCCAACCGGA ACACGGCGAACCTCAACGCGCTGGTCGACCTAGAC

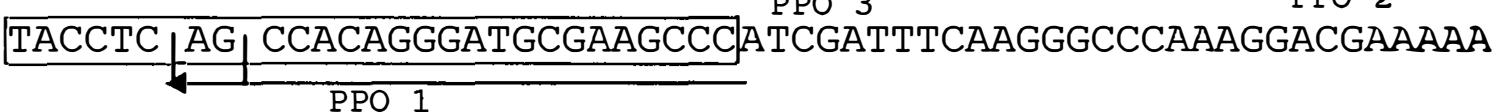

TACAAGGAACTTGTTAACAAGAACCTGTGCACCGTATACAACCAGCAAGTGCGTAAGGG

CCCGGAGTCGTTCCTGGGCGAGAAGTTCTGCACCGCCATCGATGGCACCAGCGGCATGG GTTCGCTGGAGCGGATGGCGCACACCGCCATGCACGTCTGGGTCGGCAAGGCGGGCGCG AAGCCTTGCGACGCCGCCGGCGGCGGCGTCCTGAGCCACAAGGATAATGGCGCGTTCAA CTGCAACAACGACATGGGGTTCCTGGGGTCGGCCGGGAACGACCCACTCTTCTACTCGC ACCACTCCAACGTGGACCGCATGTGGCACCTCTGGTCCACCAGGATGGGCGGCGGGCAG GGCATCACGGAC *CCGGACTGGCTGGACGCCAGCTTCGTCTTCTACGACGACGTCAAGA GCCCGCGGAAGGTGCGCATCAAGTTCCGCGACGTCGTGGACACGCGCGACCTCGGCTAC ACGTACGACCCCGAGTACGACAGGGACCTGCCGTGGCTGCGGCCCAAGATCACGACGCT GGTGCCCCACGGCAAGGACAGCGGCGGCGCGGCGGCGAGGTCGTCGGCGGCGCCGCCGG TGTTCCCGCTCGCTCTGACCAAGGGCCAGGTCGTGGAGGTGCCGGCCGTGGCCGTGCCG GCCAGGGAGGCGGGGAAGGAGCAGCTGCTGGTGATCGACGGCATCGACTTCGACCCGCA GGCGAACAACAAGTTCGACGTCGCCATCAACCTGCCCGCGGACaaggCGCTGCaggTGG GGCCGCAGTACAAGGAGTACGCCGGGAGCTTCGCCGTCGTGCCGGGCTCCGGGGCCGGC GAGACGCGGAAGGGGAAggtCTCCCTCTGCATCACCGACGTGCTGTACGACCTCGACGC GGAGGACGATAGCACCGTCGACGTCGTTATCGTGCCGCGCACAGCTGCCAAggTGACGA TCAACGTTCGCCCCACCATCAAGAATCGCAAGTAGCTAACCTTGCTACTACAGTAGTCC TCGGTCGCGATTGTGTGGTCAATGACGTCGACATCGTTTCATGCACAGCTGATTGCGAC ACCGGTAGGGTGTCCGCAAGAATAAACTTATTGTAGTACCAGCTGATTGCATTGAGTGG TTTATATTAGGAAAGAGCCCGTGGTAGCTGCTGTTGGAGCAGGGCCTTGGTCCGGGTGC AGAATCAGTTCGAGACTGCATTCCAAATTGTATTCAGACcttgTTGGCCAATGATTTGG CCGCTGTTTCTGAGTAATGGAGTTCCACTTCCATGTTAAAAAAAAAAAAAAAAG 3 '

Figura 9 - Locais onde foram desenhados os iniciadores especificos para 0 gene PPO estão em destaque 
Iniciadores arbitrários:

AD1: 5' NTCGA(G/C)T(A/T)T(C/C)G(A/T)GTT 3'

AD2: 5' NGTCGA(G/C)?(A/T)GANA(A/T)GAA 3'

AD3: 5' (A/T)GTGNAG(A/T)ANCANAGA 3'

PAT1: 5' TG(A/T)GNAG(A/T)ANCA(G/C)AGA 3'

PAT2: 5' AG(A/T)GNAG(A/T)ANCA(A/T)AGG 3'

PAT3: 5' CA(A/T)CGICNGAIA(G/C)GAA 3'

PAT4: 5' TC(G/C)TICGNACIT(A/T)GGA 3'

A1: 5' CAGGCCCTTC 3'

A2: 5' TGCCGAGCTG 3'

A3: 5' AGTCAGCCA 3'

A4: 5' AATCGGGCTG 3'

A5: 5' AGGGGTCTTG 3'

As reações de PCR (PCR primário, secundário e terciário) foram preparadas como mostrado na Tabela 2.

Após o término do PCR primário, $1 \mu \mathrm{L}$ de uma diluição de $1 / 50$ de cada tubo de reação do PCR primário foi utilizada como DNA molde na reação secundária. Na reação de PCR terciário, foi usado $1 \mu \mathrm{L}$ de uma diluição 1/10 das reações secundárias. 
Tabela 2. Reações primária, secundária e terciária da técnica de PCR-TAIL

\begin{tabular}{|c|c|c|c|}
\hline \multirow{2}{*}{ Componentes } & \multicolumn{3}{|c|}{ Reações } \\
\hline & Primária & Secundária & Terciária \\
\hline DNA & $0,3 \mu l$ & $\begin{array}{l}1,0 \mu \mathrm{l}(1 / 50 \mathrm{da} \\
\left.\text { reação } 1^{\text {ária }}\right)\end{array}$ & $\begin{array}{l}1,0 \mu \mathrm{l}(1 / 10 \mathrm{da} \\
\left.\text { reação } 1^{\text {ária }}\right)\end{array}$ \\
\hline Tampão PCR 10x & $2,0 \mu \mathrm{l}$ & $2,0 \mu l$ & $2,0 \mu \mathrm{l}$ \\
\hline $\mathrm{MgCl}_{2}(50 \mathrm{mM})$ & $1,0 \mu l$ & $1,0 \mu l$ & $1,0 \mu l$ \\
\hline dNTP (10 mM) & $0,5 \mu \mathrm{l}$ & $0,5 \mu l$ & $0,5 \mu l$ \\
\hline $\begin{array}{l}\text { Iniciador específico (40 } \\
\text { picomoles) }\end{array}$ & $0,25 \mu \mathrm{l}$ & $0,25 \mu \mathrm{l}$ & $0,25 \mu \mathrm{l}$ \\
\hline $\begin{array}{l}\text { Iniciadores arbitrários (40 } \\
\text { picomoles) }\end{array}$ & $1,0 \mu l$ & $1,0 \mu \mathrm{l}$ & $0,5 \mu \mathrm{l}$ \\
\hline Água deionizada & $14,75 \mu \mathrm{l}$ & $14,05 \mu !$ & $14,55 \mu \mathrm{l}$ \\
\hline Taq DNA polimerase & $0,2 \mu l$ & $0,2 \mu l$ & $0,2 \mu l$ \\
\hline
\end{tabular}

Inicialmente foram testados os iniciadores para verificar como os resultados da técnica PCR-TAIL terciário deveriam ser ("gabarito"). Nas reações de amplificação foram utilizados $0,25 \mu \mathrm{l}$ de DNA molde , 2,5 $\mu \mathrm{L}$ de tampão (10x concentrado), $1 \mu \mathrm{L}$ de cloreto de magnésio $50 \mathrm{mM}, 1,0 \mu \mathrm{L}$ de mix de deoxiribonucleotídeo trifosfato.(dNTPs) $10 \mathrm{mM}, 0,5 \mu \mathrm{L}$ de cada iniciador (PPO ou HEL 40 picomoles), $0,5 \mu \mathrm{L}$ do iniciador reverso, $0,4 \mu \mathrm{L}$ da enzima taq DNA polimerase e água deionizada estéril para completar $25 \mu \mathrm{L}$ de reação. $\mathrm{O}$ programa utilizado no termociclador foi:

- $94^{\circ} \mathrm{C}$ por 3 minutos

- $94^{\circ} \mathrm{C}$ por 30 segundos

- $55^{\circ} \mathrm{C}$ por 30 segundos

- $72^{\circ} \mathrm{C}$ por 2 segundos

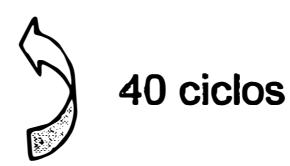

- $\quad 72^{\circ} \mathrm{C}$ por 7 minutos 
Na Tabela 3 estão apresentados os ciclos usados no PCR TAIL. Como podemos observar, muitas são as variáveis que podem interferir no processo de amplificação.

Tabela 3. Conjunto de ciclos utilizados na reação PCR-TAIL

\begin{tabular}{|c|c|c|c|}
\hline Reação & Programa & $\begin{array}{c}N^{o s} \\
\text { Ciclos }\end{array}$ & Temperaturas/tempos \\
\hline \multirow[t]{5}{*}{ Primário } & 1 & 1 & $93^{\circ} \mathrm{C}, 1 \mathrm{~min} ; 95^{\circ} \mathrm{C}, 1 \mathrm{~min}$ \\
\hline & 2 & 5 & $94^{\circ} \mathrm{C}, 30 \mathrm{seg} ; 55^{\circ} \mathrm{C}, 1 \mathrm{~min} ; 72^{\circ} \mathrm{C}, 2,5 \mathrm{~min}$ \\
\hline & 3 & 1 & $\begin{array}{l}94^{\circ} \mathrm{C}, 30 \mathrm{seg} ; 25^{\circ} \mathrm{C}, 3 \mathrm{~min} \text {; ramping para } 72^{\circ} \mathrm{C} \\
(\mathrm{em} 3 \mathrm{~min}), 72^{\circ} \mathrm{C}, 2,5 \mathrm{~min}\end{array}$ \\
\hline & 4 & 15 & $\begin{array}{l}94^{\circ} \mathrm{C}, 10 \mathrm{seg} ; 60^{\circ} \mathrm{C}, 1 \mathrm{~min} ; 72^{\circ} \mathrm{C}, 2,5 \mathrm{~min} ; \\
94^{\circ} \mathrm{C}, 10 \mathrm{seg} ; 60^{\circ} \mathrm{C}, 1 \mathrm{~min}, 72^{\circ} \mathrm{C}, 2,5 \mathrm{~min} ; \\
94^{\circ} \mathrm{C}, 10 \mathrm{seg} ; 35^{\circ} \mathrm{C}, 1 \mathrm{~min}, 72^{\circ} \mathrm{C}, 2,5 \mathrm{~min}\end{array}$ \\
\hline & 5 & 1 & $72^{\circ} \mathrm{C}, 2,5 \mathrm{~min}$ \\
\hline \multirow[t]{2}{*}{ Secundário } & 6 & 12 & $\begin{array}{l}94^{\circ} \mathrm{C}, 30 \mathrm{seg} ; 50^{\circ} \mathrm{C}, 1 \mathrm{~min}, 72^{\circ} \mathrm{C}, 2,5 \min 94^{\circ} \mathrm{C} \text {, } \\
30 \mathrm{seg} ; 50^{\circ} \mathrm{C}, 1 \mathrm{~min}, 72^{\circ} \mathrm{C}, 2,5 \min 94^{\circ} \mathrm{C}, 30 \\
\text { seg; } 35^{\circ} \mathrm{C}, 1 \mathrm{~min}, 72^{\circ} \mathrm{C}, 2,5 \min \end{array}$ \\
\hline & 5 & 1 & $72^{\circ} \mathrm{C}, 2,5 \mathrm{~min}$ \\
\hline \multirow[t]{2}{*}{ Terciário } & 7 & 20 & $94^{\circ} \mathrm{C}, 15 \mathrm{seg} ; 35^{\circ} \mathrm{C}, 1 \mathrm{~min}, 72^{\circ} \mathrm{C}, 2,5 \mathrm{~min}$ \\
\hline & 5 & 1 & $72^{\circ} \mathrm{C}, 2,5 \mathrm{~min}$ \\
\hline
\end{tabular}

Fonte: Liu \& Whittier (1995)

\subsubsection{Segunda etapa}

$\mathrm{Na}$ segunda etapa, após ter obtido um primeiro fragmento tanto para o gene HEL quanto para o gene PPO, na primeira etapa, foram desenhados outros iniciadores específicos para ambos os genes a partir destes novos fragmentos. 
Todo procedimento apresentado para a primeira etapa foi repetido nessa segunda etapa. Além dos iniciadores arbitrários citados na primeira etapa, também foram usados:

-A06: 5' GTGATCGCAG 3'

-A07: 5' CAATCGCCGT 3'

-A08: 5' TGCTCTGCCC 3'

-A09: 5' GGTGACGCAG 3'

-A10: 5' GTCCACACGG 3'

-A11: 5' TGGGGGACTC 3'

-A12: 5' CTGCTGGGAC 3'

-A13: 5' GTAGACCCGT 3'
-A14: 5' CCTTGACGCA 3'

-A15: 5' GACGGATCAG 3'

-A16: 5' TGAGTGGGTG 3'

-A17: 5' CCCAAGGTCC 3'

-A18: 5' ACGGATCCTG 3'

-A19: 5' GAGGATCCCT 3'

-A20: 5' GGTGCGGGAA 3'

Os iniciadores especificos utilizados foram:

a) Iniciadores especificos para $H E L$

HEL10: 5' CTGCAGAACATTTCCCTACT 3'

HEL09: 5' GGCTTGCGTACCGGCCCAGG 3'

HEL08: 5' GTTAATAATACATAGAGTCA 3'

HEL07: 5' GTAGACAAGTACGACGACCA 3'

HEL06: 5' GTTTATCCCTTGATCTCACC 3'

b) Iniciadores específicos para PPO:

PPO10: 5' GGCCGCTTCGCATCCCTGTG 3'

PPO09: 5' CCCGGGTACCAGGCGAGCCC 3'

PPO08: 5' CGTGCACGGCGAAGACGACG 3'

PPO07: 5' CTCGTTCACCTTGTCCGCCG 3'

PPO06: 5' GCAAGATCTTCTCGTTCACC 3' 


\subsubsection{Purificação dos fragmentos amplificados pela técnica PCR-TAIL}

Os fragmentos desejados obtidos pela técnica PCR-TAIL foram retirados do gel $1 \%(p / v)$ agarose com auxílio de um bisturi e purificados utilizando-se o kit QUIAEX || Gel Extraction (Qiagen), de acordo com especificações do fabricante.

\subsubsection{Clonagem dos produtos do PCR-TAIL}

Para clonagem dos produtos do PCR-TAIL foi utilizado o sistema pGEMQ-T Easy Vector (Promega).

A relação inserto: vetor utilizada foi de $3: 1$ e utilizou-se o seguinte cálculo, fornecido pelo fabricante, para realizar as reações de ligação:

$$
n g \text { do inserto }=\frac{n g \text { do vetor } \times k b \text { (tamanho do inserto })}{k b(\text { tamanho do vetor })} \times \frac{3}{1}
$$

Sabendo-se, pelo fabricante, que o vetor pGEM®-T Easy Vector possui $3 \mathrm{~kb}$ e $50 \mathrm{ng} / \mu \mathrm{l}$ determinou-se o tamanho e a concentração do inserto por meio do gel de agarose e o marcador $1 \mathrm{~kb}$. A reação foi composta como apresentado na Tabela 4.

Tabela 4. Reação de ligação usando pGEM®-T Easy Vector

\begin{tabular}{lcc}
\hline Componente & Controle positivo & amostra \\
\hline Tampão de ligação 2x & $5 \mu \mathrm{l}$ & $5 \mu \mathrm{l}$ \\
pGEM®-T Easy Vector (50 ng) & $1 \mu \mathrm{l}$ & $1 \mu \mathrm{l}$ \\
Produto do PCR & -- & $X \mu \mathrm{l}$ \\
Inserto de DNA controle & $2 \mu \mathrm{l}$ & - \\
T4 DNA ligase & $1 \mu \mathrm{l}$ & $1 \mu \mathrm{l}$ \\
Água deionizada (q.s.p.) & $10 \mu \mathrm{l}$ & $10 \mu \mathrm{l}$ \\
\hline
\end{tabular}

A reação foi incubada a $4{ }^{\circ} \mathrm{C}$ por 16 horas para posterior transformação das bactérias. 


\subsubsection{Avaliação da transformação por PCR diretamente nas bactérias}

Na reação de PCR para seleção das colônias, uma pequena quantidade de bactéria foi inoculada em $25 \mu$ de água deionizada e lisadas a $94{ }^{\circ} \mathrm{C}$. Adicionou-se em cada reação, uma mistura contendo $16,2 \mu \mathrm{l}$ de água estéril, 5 $\mu l$ de tampão para PCR (10x), $2 \mu \mathrm{l}$ de $\mathrm{MgCl}_{2}(50 \mathrm{mM}), 0,5 \mu \mathrm{l}$ de dNTP (deoxiribonucleotídeo trifosfato) mix (10 mM), 0,5 $\mu$ do iniciador universal, $0,5 \mu \mathrm{l}$ do iniciador reverso e $0,3 \mu$ de Taq DNA polimerase $(5 \mathrm{u} / \mu \mathrm{l})$. O ciclo de amplificação foi composto de:

- $95^{\circ} \mathrm{C}$ por 2 minutos

- $\quad 95^{\circ} \mathrm{C}$ por 30 segundos

- $\quad 50^{\circ} \mathrm{C}$ por 30 segundos

- $72^{\circ} \mathrm{C}$ por 2 minutos

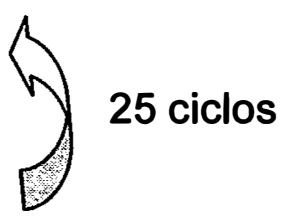

- $\quad 72^{\circ} \mathrm{C}$ por 7 minutos

3.2.6 Minipreparação de DNA de plasmídeo dạs colônias bacterianas selecionadas, usando lise-alcalina

As bactérias de interesse foram mantidas individualmente em $3 \mathrm{~mL}$ meio LB contendo antibiótico de seleção (ampicilina $100 \mathrm{mg} / \mathrm{mL}$ ) por toda à noite com agitação a $37^{\circ} \mathrm{C}$.

Essa solução de bactérias foi transferida para tubo de $1,5 \mathrm{~mL}$, centrifugada por 1 minuto e em seguida desprezou-se a solução sobrenadante (em água sanitária).

O pellet foi ressuspendido em $200 \mu \mathrm{l}$ da solução I [59 mM glucose, 25 $\mathrm{mM}$ Tris- $\mathrm{HCl}, \mathrm{pH} 8,0,10 \mathrm{mM} \mathrm{Na}$. EDTA], no vórtex e mantido por 10 minutos à temperatura ambiente. Em seguida foram adicionados $200 \mu$ da solução II [0,2 $\mathrm{M} \mathrm{NaOH}, 1,0 \%$ SDS] e os tubos mantidos no gelo por 5 minutos. 
Na seqüência foram adicionados $150 \mu$ da Solução III [3 M KOAc, pH $5,5]$, os tubos incubados no gelo por 5 minutos e centrifugados por 10 minutos (até o pellet ficar sólido). A solução sobrenadante foi transferida (contendo o DNA plasmidial) para outro tubo de $1,5 \mathrm{~mL}$, adicionados $500 \mu \mathrm{l}$ de fenol:clorofórmio:álcool isoamílico (25:24:1) e centrifugados por 5 minutos. A fase superior aquosa foi coletada e transferida para um tubo de 1,5 mL novo onde foram adicionados $500 \mu \mathrm{l}$ de clorofórmio:álcool isoamílico $(24: 1)(\mathrm{v} / \mathrm{v})$, misturados e centrifugados de novo por 1 minuto. A fase aquosa superior foi coletada e transferida para um outro tubo de $1,5 \mathrm{~mL}$ onde foi adicionado $1 \mathrm{~mL}$ de etanol absoluto e incubado a $-20^{\circ} \mathrm{C}$ por meia hora.

$\mathrm{Na}$ seqüência os tubos contendo DNA foram centrifugados por 5 minutos numa microcentrífuga, depois retirado o etanol absoluto, adicionados $500 \mu \mathrm{l}$ de etanol $70 \%(\mathrm{v} / \mathrm{v})$ e os tubos centrifugados por 5 minutos. Posteriormente 0 etanol foi retirado e o pellet seco ao ar. O DNA foi ressuspendido em água.

\subsubsection{Sequenciamento dos fragmentos obtidos nas reações PCR-TAIL}

Alguns clones positivos foram enviados para seqüenciamento automático conforme descrito no item 3.1.2.8.

\subsubsection{Busca por motivos regulatórios}

Para o gene do tipo heveína (HEL), que apresentava o Read/SUCEST completo, após o sequenciamento dos fragmentos obtidos nas reações de PCR-TAIL analisou-se as seqüências utilizando o programa PLACE database (http://uww.dna.affrc.go.jp/htdocs/PLACE/)(Higo et al., 1999) que realiza buscas de motivos regulatórios na seqüência em estudo, por meio de comparações com uma biblioteca contendo sítios de ligação a fatores de transcrição encontrados em promotores de plantas.

Para o gene da polifenol oxidase (PPO), cujo Read/SUCEST não estava completo foi realizada uma análise comparativa no banco de dados GENBANK, 
por meio de pesquisa no BLAST (basic local alignment search tool) (Altschul et al., 1997) (http:// www.ncbi.nlm.nih.gov/BLAST) usando o resultado proveniente do sequenciamento do fragmento isolado. Também foi procedido o alinhamento das seqüências utilizadas por meio da opção BLAST 2 SEQUENCES (http://uww.ncbi.nlm.nih.gov/blast/bl2seq/bl2.html).

\subsubsection{Caracterização do promotor induzido por ferimento}

Para determinar e analisar a presença de regiões regulatórias, bem como verificar quais motivos regulatórios eram realmente importantes tanto para a expressão temporal quanto espacial e descobrir qual era a região promotora mínima, foram feitas várias construções gênicas (deleções a partir da extremidade $3^{\prime}$ envolvendo o gene repórter uidA, que codifica a enzima $\beta$ glucuronidase.

Para isso utilizou-se o vetor pCAMBIA 1281Z, no qual o gene gus está desprovido de região promotora, que foi devidamente projetado para a clonagem e caracterização de regiões promotoras em plantas (Roberts et al., 1997).

\subsubsection{Construções gênicas}

Foram feitas três construções gênicas para a identificação da região promotora mínima, bem como a contribuição das diferentes regiões no padrão de atividade do promotor.

Para a primeira construção gênica com aproximadamente 211 pares de base (A-D) foram desenhados dois iniciadores a fim de amplificarem a região correspondente ao início do transcrito $(+1)$ atingindo e abrangendo até a possivel região TATA-BOX.

Os iniciadores utilizados para a amplificação apresentavam em suas extremidades sítios de restrição, para facilitar a clonagem, e foram preparados de forma a estarem em fase de leitura com o vetor de expressão em plantas. 
É necessário ressaltar que o iniciador $\mathbf{A}$ foi utilizado em todas as construções. Esses iniciadores foram:

-Iniciador D: 5' GGG GGATCC CGGCGCACCCAGACC 3'

BamH I

-Iniciador A: 5' GGG CCATGG GCCTCTTACTGTTGC 3'

NCOI

A segunda construção (A-C) compreendeu um fragmento de aproximadamente 600 pares de base que englobava a região TATA-BOX mais alguns motivos de acordo com o programa PLACE database (http://www.dna.affrc.go.jp/htdocs/PLACE/). $O$ iniciador desenhado para amplificar esse fragmento foi:

-Iniciador C: 5' GGG GGATCC ACACGAGGGCCGTGC 3'

BamHI

A terceira construção (A-B) compreendeu o fragmento completo de aproximadamente 1100 pares de base sendo o iniciador:

- Iniciador B: 5' GGG GGATCC AGTAGGGAATGTTC 3'

$\mathrm{BamHI}$

\subsubsection{Construção dos vetores para transformação}

Os iniciadores descritos no item 3.2.9.1 foram utilizados para amplificar os fragmentos utilizando-se como molde, o DNA genômico da cana-de-açúcar ou o vetor pGEM®-T Easy contendo todo o fragmento obtido por PCR-TAIL correspondente ao possivel promotor induzido. 
Nas reações de amplificação foram utilizados $1 \mu \mathrm{l}$ de DNA molde , 5,0 $\mu \mathrm{L}$ de tampão da enzima Pfx $10 x$ concentrado, $1 \mu \mathrm{L}$ de cloreto de magnésio 50 $\mathrm{mM}, 1,5 \mu \mathrm{L}$ de mix de dNTPs (deoxiribonucleotídeo trifosfato) $10 \mathrm{mM}, 0,5 \mu \mathrm{L}$ de cada iniciador (B ou $C$ ou $D$ ), $0,5 \mu L$ do iniciador $A, 0,4 \mu L$ da enzima $P f x$ polimerase e água deionizada para completar $50 \mu \mathrm{L}$ de reação.

O programa utilizado no termociclador foi:

$-94^{\circ} \mathrm{C}$ por 2 minutos $-95^{\circ} \mathrm{C}$ por 15 segundos $-55^{\circ} \mathrm{C}$ por 30 segundos $-68^{\circ} \mathrm{C}$ por 2 minuto

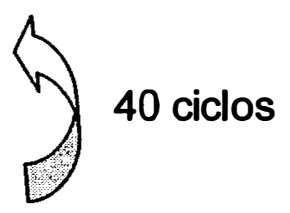
$-4^{\circ} \mathrm{C}$

Os fragmentos desejados obtidos pelo PCR foram então purificados do gel de $1 \%(p / v)$ agarose utilizando o Kit QIAEX // gel extraction (QIAGEN) para serem utilizados nas etapas subseqüentes.

Os fragmentos purificados do gel e o vetor pCAMBIA $1281 \mathrm{Z}$ foram digeridos com as enzimas de restrição BamHI e Ncol (Invitrogen) e novamente purificados do gel com o mesmo Kit anterior.

Em seguida foram feitas as reações de ligação compostas por 3,0 $\mu \mathrm{L}$ de tampão ligase $5 \mathrm{x}, 1$ ou $2 \mu \mathrm{L}$ dos insertos (A-B ou $A-c$ ou $A-D), 1 \mu \mathrm{L}$ do vetor pCAMBIA 1281Z, 1,5 $\mu \mathrm{L}$ da enzima DNA ligase e água deionizada suficiente para completar $15 \mu \mathrm{L}$ de reação. Os tubos foram mantidos por 16 horas a $16^{\circ} \mathrm{C}$ no termociclador.

Os produtos das reações de ligações foram utilizados para transformar células competentes de Escherichia coli, por choque térmico, como descrito no item 3.1.2.8.2. As colônias foram selecionadas em placas de Petri com meio de cultura sólido contendo o antibiótico cloranfenicol $(25 \mathrm{mg} / \mathrm{mL}), 40 \mu \mathrm{l}$ X-gal $(20 \mathrm{mg} / \mathrm{mL})$ e $4 \mu \mathrm{l}$ IPTG $(200 \mathrm{mg} / \mathrm{mL})$ e mantidas a $37^{\circ} \mathrm{C}$ durante 16 horas. 
A avaliação da transformação (seleção por PCR diretamente nas bactérias) foi realizada como descrito no item 3.2.5.

$\mathrm{Na}$ seqüência foram feitas minipreparações de DNA de plasmídeo das colônias bacterianas selecionadas, a reação de sequenciamento e levadas para sequenciar como descrito no item 3.1.2.8.

Posteriormente foram realizadas midipreparações de DNA de plasmídeo das colônias bacterianas selecionadas, seguindo as orientações do manual do QIAGEN Plasmid Mini Kit (Qiagen) para posterior transformação das plantas de cana-de-açúcar.

\subsubsection{Transformação de plantas de cana-de-açúcar}

Toda a parte de transformação foi realizada no Centro de Tecnologia Copersucar.

As midipreparações de DNA de plasmídeo das colônias bacterianas selecionadas foram quantificadas e levadas no Centro de Tecnologia Copersucar para transformação de calos de cana-de-açúcar, contando com a valiosa ajuda da Dra. Maria Cristina Falco. Foi utilizado o método da biobalística como descrito em Falco et al. (2000).

As plantas foram transformadas com as seguintes construções gênicas: -pCAMBIA $1281 Z$ contendo o fragmento A-B de aproximadamente 1100 pares de base;

-pCAMBIA $1281 Z$ contendo o fragmento A-C de aproximadamente 600 pares de base;

-pCAMBIA $1281 Z$ contendo o fragmento A-D de aproximadamente 211 pares de base.

Como controle negativo foi usado o vetor pCAMBIA $1281 \mathrm{Z}$ fechado e como controles positivos o vetor pCAMBIA 1301 fechado, pois contém o promotor constitutivo $35 \mathrm{~S}$ e o vetor pAHC 27, que está na cepa $\mathrm{DH} 5 \alpha$ e 
derivado do plasmídeo PUC19, contendo o promotor da ubiquitina do milho (Ubi-1) e o gene gus ( $\beta$-glucuronidase).

Inicialmente foi utilizada a seleção com o antibiótico higromicina, pois o vetor pCAMBIA 1281Z, utilizado para transformação, possui o gene de resistência a este antibiótico. Mas, devido ao fato das plantas não estarem se desenvolvendo muito bem foi mudado para o sistema de co-transformação, método usado na Copersucar, e a seleção feita por meio do antibiótico geneticina (Falco \& Silva-Filho, 2003).

As transformações foram feitas com freqüência de forma a ter simultaneamente sempre várias repetições nas diferentes fases do desenvolvimento das plantas de cana-de-açúcar.

\subsubsection{Identificação de plantas de cana-de-açúcar transgênicas por reação em cadeia da polimerase (PCR)}

Para verificar se as plantas eram realmente transformadas, foi feito PCR utilizando os iniciadores específicos da possível região promotora do gene HEL e um iniciador que se anela na região do vetor onde se encontrada o gene uidA (5' CGTTCTACAGGACGGACGA 3').

\subsubsection{Isolamento de DNA genômico de plantas de cana-de-açúcar}

Para o isolamento do DNA genômico das plantas transformadas de cana-de-açúcar, para ser usado nos PCRs de identificação das plantas transgênicas, utilizou-se o reagente DNAzol (GiBCOBRL®) e foram seguidas as especificações fornecidas pelo fabricante que acompanham o reagente:

\subsubsection{Reação em cadeia da polimerase (PCR)}

Nas reações de amplificação por PCR foram utilizados $1 \mu \mathrm{l}$ de DNA molde das supostas plantas transgênicas e controle, $2,5 \mu \mathrm{L}$ de tampão (10x 
concentrado), 1,5 $\mu \mathrm{L}$ de cloreto de magnésio $50 \mathrm{mM}, 0,5 \mu \mathrm{L}$ de mix de dNTPs (deoxiribonucleotídeo trifosfato) $2,5 \mathrm{mM}, 0,5 \mu \mathrm{L}$ de cada iniciador, $0,3 \mu \mathrm{L}$ da enzima taq DNA polimerase e água deionizada estéril para completar $25 \mu \mathrm{L}$ de reação.

O programa utilizado no termociclador foi:

$-94^{\circ} \mathrm{C}$ por 3 minutos

$-94^{\circ} \mathrm{C}$ por 30 segundos

$-45^{\circ} \mathrm{C}$ por 30 segundos

$-72^{\circ} \mathrm{C}$ por 2 minutos

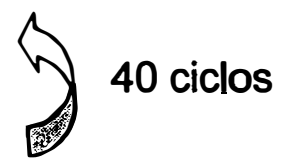

$-72^{\circ} \mathrm{C}$ por 7 minutos

Os produtos do PCR foram analisados em gel de 1\% (p/v) agarose com tampão de corrida TBE 0,5x (45 mM Tris- $\mathrm{HCl}$ e $1 \mathrm{mM}$ ácido etileno diamono tetracético - EDTA) e coloração com brometo de etídeo.

Para as plantas transformadas com as construções A-B, A-C e A-D foram utilizados respectivamente os iniciadores $B, C$ e $D$ descritos no item 3.2.9.1, que se anelam na região promotora isolada, combinados cada um deles com o iniciador GUS (5' CCCTCAGATCTACCATG $\left.3^{\prime}\right)$ que se anela na região do gene gus, que codifica a enzima $\beta$-glucuronidase (GUS). Como controle positivo dessas plantas foi utilizado a midipreparação contendo o vetor pCAMBIA $1281 z$ mais as construções dos promotores, como DNA molde do PCR.

Para as plantas transformadas com os vetores $1281 \mathrm{z}$ fechado, pCAMBIA 1301 e pAHC 27 foram utilizados os iniciadores GUS3 (5' CGTTCTACAGGACGGACGA 3') e GUS 5 (5'ATGGTAGATCTGAGGG 3'), que se anelam na região do gene gus para amplificação. Como controle positivo foram utilizadas as midipreparações contendo somente esses vetores. 
Como controles negativos de cada construção gênica foram utilizados o DNA de plantas não transformadas e água como molde para o PCR.

\subsubsection{Análise molecular dos promotores}

\subsubsection{Expressão transiente em células de epiderme de cebola}

A fim de verificar se a região clonada (1100 pares de bases) era capaz de dirigir a expressão do gene repórter uidA (GUS), foi realizado um ensaio preliminar de expressão transiente em células da epiderme de cebola com três diferentes vetores.

Como controle positivo, utilizou-se o vetor pCAMBIA 1301, que contém o 35S-GUS como cassete de expressão em plantas.

Como controle negativo, foi utilizado o vetor pCAMBIA 1281Z, no qual o gene uidA não apresenta uma região regulatória, portanto, a proteína GUS não é expressa.

\subsubsection{Transformação}

$O$ vetor pCAMBIA 1281Z+1100pb+GUS (construção $A-B$ ), juntamente com as outras construções (controles) foram introduzidos nas células de cebola via método da biobalística.

Para isso as cebolas (camada intermediária) foram cortadas em quadrados e colocadas dentro de uma placa de Petri com um pouco de água destilada até o uso (sem molhar a superfície de cima para não interferir na transformação). As partículas de tungstênio (50 $\mu \mathrm{L}$ ) preparadas foram sonicadas para que ficassem em suspensão para uma eficiente adesão do DNA.

Para evitar eventuais contaminações foi mantida a seguinte ordem das amostras: controle negativo, seguido das construções e por último o controle positivo. 
Foram adicionados na ordem, agitando sempre durante e após a adição: - 5-8 $\mu$ I DNA $(1 \mu \mathrm{g} / \mu \mathrm{L})$ - midipreparação das amostras (construção A-B e controles negativo - vetor pCAMBIA $1281 \mathrm{Z}$ fechado e positivo - vetor PCAMBIA 1301 fechado);

- $50 \mu \mathrm{L} \mathrm{CaCl} 2(2,5 \mathrm{M})$;

- $20 \mu \mathrm{L}$ espermidina $(0,1 \mathrm{M})$.

Em seguida os tubos foram mantidos sob agitação suave, no vórtex, por 10 minutos, posteriormente centrifugados por 10 segundos e o sobrenadante retirado. Foram adicionados $150 \mu \mathrm{L}$ de etanol $100 \%$ e as partículas foram ressuspendidas, centrifugadas por 10 segundos e o sobrenadante descartado novamente. Repetiu-se o passo anterior mais uma vez e na seqüência as particulas foram ressuspendidas em $25 \mu \mathrm{L}$ de etanol 100\%. Foram espalhados $8 \mu \mathrm{L}$ das partículas por membrana carreadora previamente montada.

Após secar por alguns minutos dentro da placa de Petri contendo sílica (para não pegar unidade evitando assim que as partículas se aglomerassem) foi iniciada a transformação da epiderme de cebola.

As partículas, recobertas com o DNA de interesse, foram aceleradas em direção ao tecido via um acelerador de partículas, e todos os parâmetros referentes aos disparos foram realizados conforme metodologia descrita pelo fabricante (BioRad).

O material bombardeado foi deixado em placas de Petri contendo o meio MS por 22 horas a $22^{\circ} \mathrm{C}$ no escuro (em B.O.D). Após este tempo foi verificada a atividade da enzima $\beta$-glucuronidase (GUS).

\subsubsection{Atividade da GUS}

Para verificar a atividade da GUS utilizou-se o método qualitativo, baseado na clivagem do substrato 5-bromo-4-cloro-3-indolil- $\beta$-D-glucoronídeo (X-gluc) pela $\beta$-glucuronidase. 
O produto dessa reação, na presença de oxigênio, forma dímeros, resultando em um precipitado insolúvel de cor azul (Brasileiro \& Carneiro, 1998).

Após o bombardeamento, os tecidos foram mergulhados em um tampão de reação composto de $100 \mathrm{mM}$ de $\mathrm{NaH}_{2} \mathrm{PO}_{4}, 0,5 \mathrm{mM}$ de $\mathrm{K}_{4} \mathrm{Fe}(\mathrm{CN})_{6} .3 \mathrm{H}_{2} \mathrm{O}, 10$ $\mathrm{mM}$ de $\mathrm{Na}_{2}$ EDTA. $2 \mathrm{H}_{2} \mathrm{O}, 0,1 \%$ (v/v) de Triton® X-100 e $1 \mathrm{mM}$ de X-Gluc e incubados no escuro a $37^{\circ} \mathrm{C}$ (B.O.D.) por 16 horas. Após esse período os tecidos foram observados em microscópio óptico.

\subsubsection{Ensaio biológico com as plantas de cana-de-açúcar transgênicas}

As plantas identificadas como transgênicas foram utilizadas no ensaio biológico para estudo preliminar da expressão do promotor isolado.

Para verificar se a região promotora do gene do tipo heveína de cana-deaçúcar (HEL) era realmente ativada por herbivoria, foi montado um experimento onde a atividade GUS nas plantas foi determinada via teste histoquímico (utilizando-se o substrato $\mathrm{X}$-gluc) e pelo método fluorimétrico (com o substrato MUG) no tempo 24 horas com a presença das lagartas de Diatraea saccharalis.

O ensaio foi composto por 5 plantas transformadas de cada construção gênica do promotor (A-B, A-C e A-D) e 3 plantas transformadas com os vetores pCAMBIA 1301, pAHC 27 e pCAMBIA 12812 (sem inserto) atacadas por lagartas de $D$. saccharalis de $4^{\circ}$ instar, durante 24 horas e 2 plantas de cada como controle (sem lagarta). Essas plantas foram provenientes de eventos distintos de transformação.

Após esse periodo, as plantas foram separadas em folha, caule, região próxima ao dano e raiz e armazenadas em freezer $-70^{\circ} \mathrm{C}$ para posteriormente serem usadas nos ensaios histoquímico e fluorimétrico da enzima Bglucuronidase (GUS). 


\subsubsection{Ensaio histoquimico da enzima ß-glucuronidase (GUS)}

As diferentes partes das plantas foram incubadas no tampão de reação, em um volume suficiente para cobrir a amostra, cuja composição foi apresentada no item 3.2.13.3.

Em seguida foi aplicado vácuo parcial para facilitar a penetração do substrato e também fazer com que a reação fosse visível em menor espaço de tempo.

Após a incubação o tampão de reação foi retirado adicionou-se etanol $70 \%(\mathrm{v} / \mathrm{v})$ para interromper a reação e retirar a clorofila, permitindo melhor visualização da coloração azul.

As amostras foram observadas e fotografadas em microscópio estereoscópico do Centro de Tecnologia Copersucar.

\subsubsection{Ensaio fluorimétrico da enzima B-glucuronidase (GUS)}

As plantas utilizadas no ensaio histoquímico e que apresentaram coloração azul (expressão do gene gus) foram separadas para o ensaio fluorimétrico da enzima B-glucuronidase (GUS) com o objetivo de quantificar os niveis enzimáticos da enzima e verificar se a reposta ao ataque da lagarta foi sistêmica ou apenas local.

Os extratos foram preparados através da maceração do material vegetal (100mg) por cerca de 1 minuto em $500 \mu \mathrm{L}$ de tampão de extração composto de $100 \mathrm{mM}$ de tampão fosfato de sódio $\mathrm{pH}$ 7,0, $10 \mathrm{mM}$ de $\beta$-mercapetanol, $10 \mathrm{mM}$ de ácido etileno diamono tetracético (EDTA) $\mathrm{pH} 8,0,0,1 \%$ dodecil sulfato de sódio (SDS), $0,1 \%(\mathrm{v} / \mathrm{v})$ de Triton $\mathrm{X}-100$. Em seguida, as amostras foram centrifugadas (para a sedimentação dos tecidos vegetais macerados) a $12000 \mathrm{~g}$ por 10 minutos a $4^{\circ} \mathrm{C}$. O sobrenadante foi transferido para novo tubo e mantido no gelo. A atividade da $\beta$-glucuronidase foi determinada, misturando-se $25 \mu \mathrm{L}$ do extrato celular (sobrenadante) com $75 \mu \mathrm{L}$ de tampão de reação (tampão de 
extração acrescido de $2 \mathrm{mM}$ de 4-metillumbeliferil $\beta$-D-glucuronídeo - MUG) pré aquecido $\left(37^{\circ} \mathrm{C}\right)$.

As amostras (extrato celular mais tampão de reação) foram incubadas à $37^{\circ} \mathrm{C}$ no escuro, a reação foi interrompida em diferentes intervalos de tempo através da adição de $20 \mu \mathrm{L}$ da mistura de reação à $1,98 \mathrm{~mL}$ de tampão de parada $\left(0,2 \mathrm{M}\right.$ de $\left.\mathrm{Na}_{2} \mathrm{CO}_{3}\right)$.

Em seguida foi medida a fluorescência das amostras no fluorímetro DYNA QUANT ${ }^{T M} 200$ devidamente calibrado (solução padrão de 4metilumbeliferona - MU) seguindo todas as recomendações do fabricante (Hoefer).

3.2.16 Análise comparativa entre a região promotora do gene tipo heveina (HEL) de cana-de-açúcar e de Arabidopsis

Em Arabidopsis, foi selecionada a região acima da metionina do HEL até o códon de parada do gene seguinte.

Essa seqüência da provável região promotora do gene do tipo heveína (HEL) de Arabidopsis foi obtida do banco de dados TAIR (http://uww.arabidopsis.org) e analisada no programa PLACE database (http://www.dna.affrc.go.jp/htdocs/PLACE/) (Higo et al., 1999) para posteriormente ser comparada com a provável região promotora do gene HEL de cana-de-açúcar. 


\section{RESULTADOS E DISCUSSÃO}

\subsection{Estudo da expressão gênica em cana-de-açúcar}

\subsubsection{Estudo da expressão gênica em cana-de-açúcar por meio da análise assistida por computador}

O estudo da expressão gênica em cana-de-açúcar por meio da análise assistida por computador, a partir de informações geradas pelo projeto SUCEST cana-de-açúcar, forneceu informações preliminares sobre a expressão dos genes de interesse em diferentes tecidos da planta. Os resultados obtidos encontram-se esquematizados nas Figuras 10, 11 e 12.

Observa-se que os ESTs variam sua expressão qualitativa e quantitativamente. Para o gene do tipo heveína (HEL) a presença dos transcritos foi detectada somente em calo (CL), raiz (RT) e sementes (SD) (Figura 12), enquanto que os genes da polifenol oxidase (PPO), da cistatina (CIS), da metalotioneina (MT1) e da lipoxigenase (LOX2) apresentaram expressão em maior número de tecidos (Figuras 10 e 11), incluindo a bainha (SB), folhas (LV), colmo (ST) e zona de transição colmo-raiz (RZ) que são regiões mais afetadas pelo ataque da broca da cana (Diatraea saccharalis). 


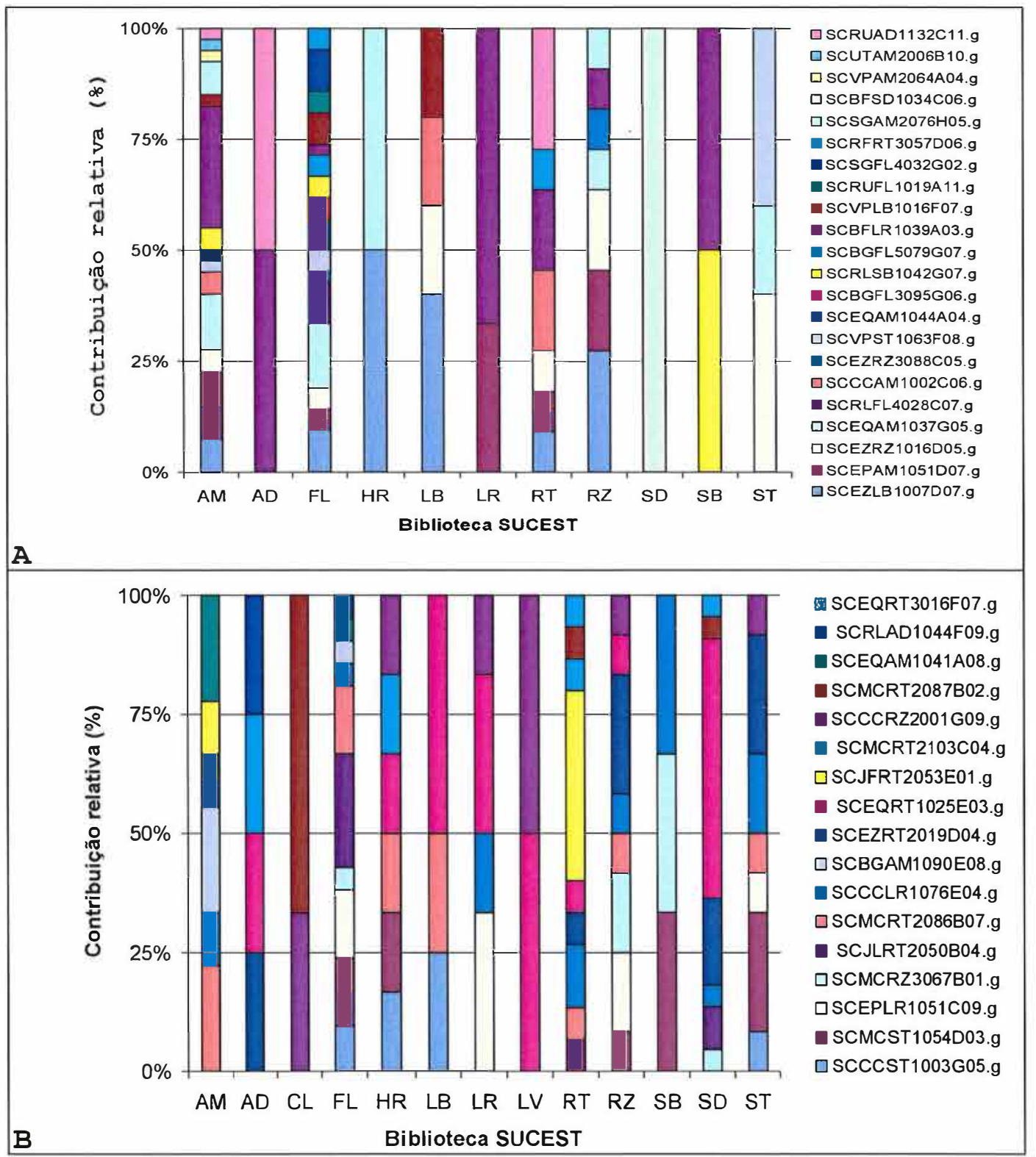

Figura 10 - Análise assistida por computador da expressão dos ESTs (representados por clusters, parte direita da figura) referentes à (A) polifenol oxidase (PPO) e (B) cistatina (CIS) de cana-de-açúcar a partir de bibliotecas de cDNA de diferentes tecidos. Abreviaturas das bibliotecas: $A M=$ meristema apical; $A D$ = plântulas in vitro sem folhas e raízes desenvolvidas infectadas com Acetobacter diazotroficans; $\mathrm{CL}=$ calos submetidos a estresse de luz e temperatura $\left(4^{\circ} \mathrm{C}\right.$ e $\left.37^{\circ} \mathrm{C}\right) ; \mathrm{FL}=$ flores; $\mathrm{HR}=$ plântulas in vitro sem folhas e com raízes desenvolvidas infectadas por Herbaspirillum rubrisubalbicans; $\mathrm{LB}=$ gema lateral; $\mathrm{LR}=$ palmito; $\mathrm{LV}=$ folhas; $\mathrm{RT}=$ raiz; $\mathrm{RZ}=$ zona de transição folha/raiz; $\mathrm{SB}=$ bainha; $\mathrm{SD}=$ sementes; $\mathrm{ST}=$ colmo 


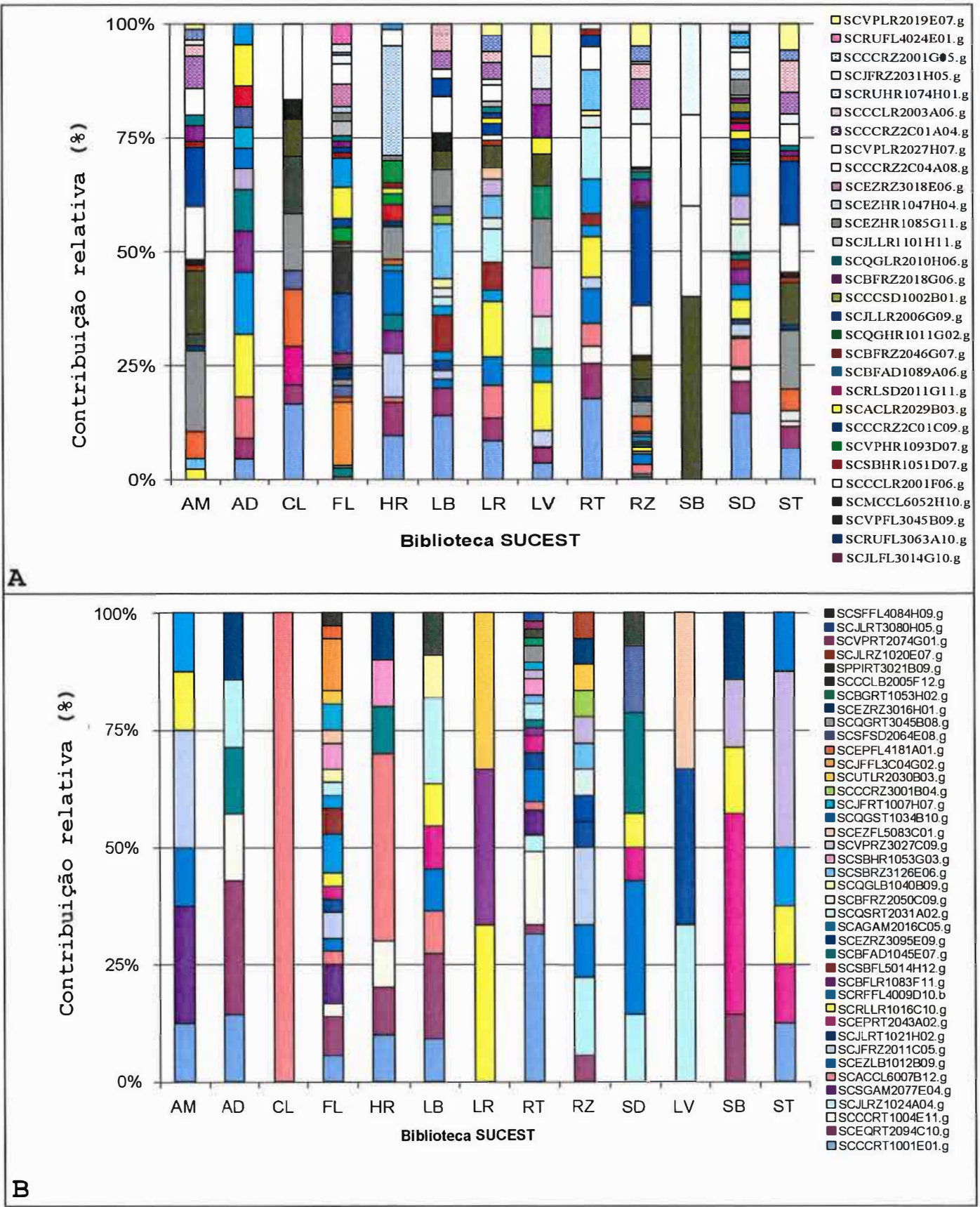

Figura 11 - Análise assistida por computador da expressão dos ESTs (representados por clusters, parte direita da figura) referentes à (A) metalotioneína (MT1) e (B) da lipoxigenase (LOX2) de cana-de-açúcar a partir de bibliotecas de CDNA de diferentes tecidos. Abreviaturas das bibliotecas: $A M=$ meristema apical; $A D=$ plântulas in vitro sem folhas e raízes desenvolvidas infectadas $100 \mathrm{~m}$ Acetobacter diazotroficans; $\mathrm{CL}=$ calos submetidos a estresse de luz e temperatura $\left(4^{\circ} \mathrm{C}\right.$ e $\left.37^{\circ} \mathrm{C}\right) ; \mathrm{FL}=$ flores; $\mathrm{HR}=$ plântulas in vitro sem folhas e com raízes desenvolvidas infectadas por Herbaspinillum nubrisubalbicans; $L B=$ gema lateral; $L R=$ palmito; $L V=$ folhas; $R T=$ raiz; $R Z$ = zona de transição folha/raiz; $\mathrm{SB}=$ bainha; $\mathrm{SD}=$ sementes; $\mathrm{ST}=$ colmo 


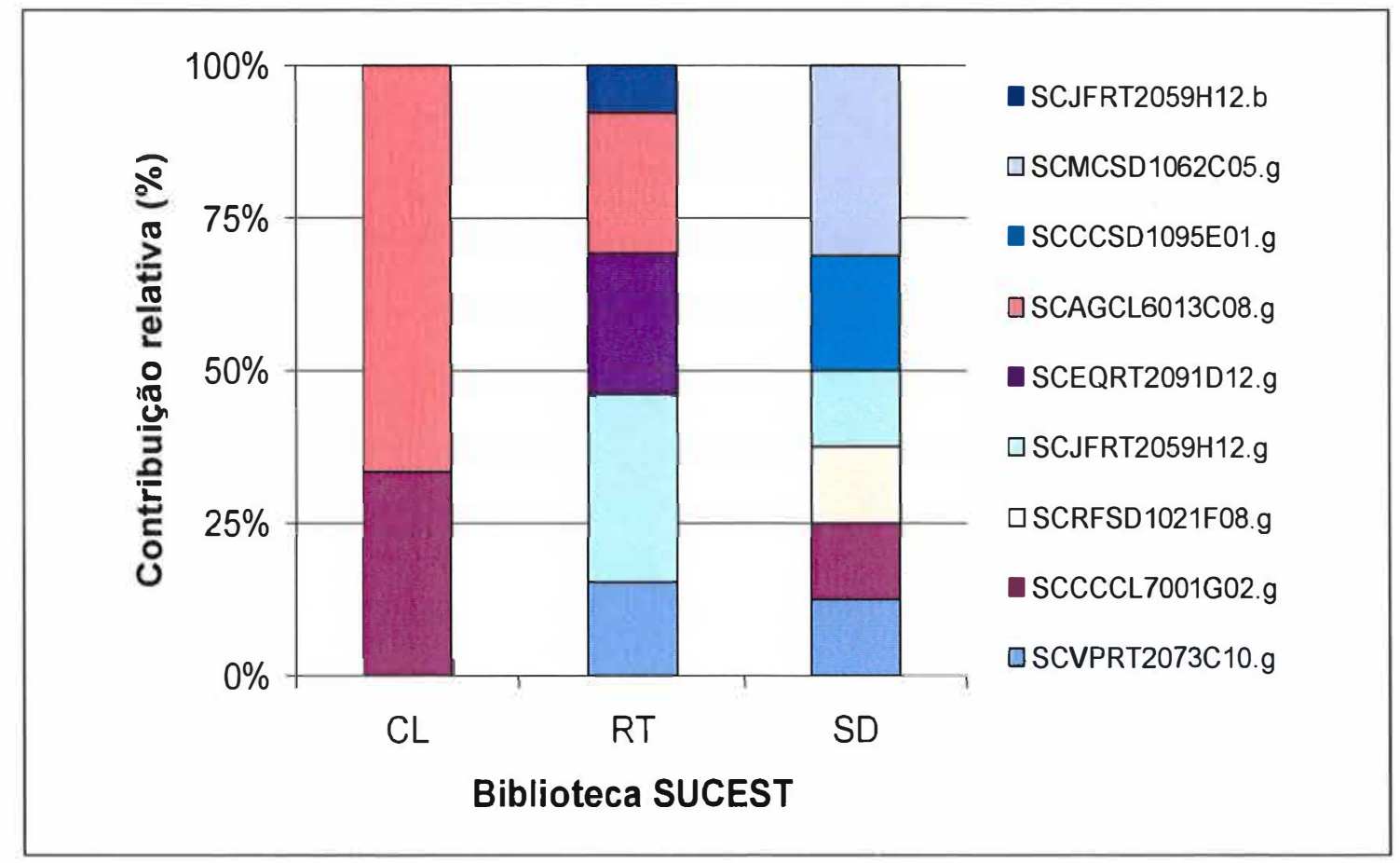

Figura 12 - Análise assistida por computador da expressão dos ESTs (representados por dusters, parte direita da figura) referer tes à tipo heveína (HEL) de cana-de-açúcar a partir de bibliotecas de cDNA de diferentes tecidos. Abreviaturas das bibliotecas: $\mathrm{CL}=$ calos submetidos a estresse de luz e temperatura $\left(4^{\circ} \mathrm{C} \mathrm{e}\right.$ $\left.37^{\circ} \mathrm{C}\right) ; \mathrm{RT}=$ raiz; $\mathrm{SD}=$ sementes

\subsubsection{Análise da expressão gênica por meio da técnica Northern Blot}

Os resultados obtidos por meio da técnica Northern Blot revelaram que realmente os genes escolhidos, tomando-se como base a literatura que os indicava como responsivos ao ataque de insetos, foram induzidos em plantas de cana-de-açúcar atacadas pela broca da cana (Diatraea saccharalis).

Observou-se também que o padrão de indução destes ESTs foi variado sugerindo uma regulação diferencial. 


\subsubsection{Gene da $\beta$-actina}

Como controle interno utilizou-se o gene da $\beta$-actina que é considerado, baseado em trabalhos da literatura, como apresentando uma expressão constitutiva em outras plantas.

Nos experimentos por herbivoria, a técnica do Northern Blot comprovou que esse gene é expresso constitutivamente em plantas de cana-de-açúcar atacadas ou não pela lagarta Diatraea saccharalis (Figura 13).

O gene da $\beta$-actina foi utilizado como controle interno por Yoda \& Sano (2003) para estudar a ativação de genes relacionados a patógenos, mostrando também que esse gene não era induzido.

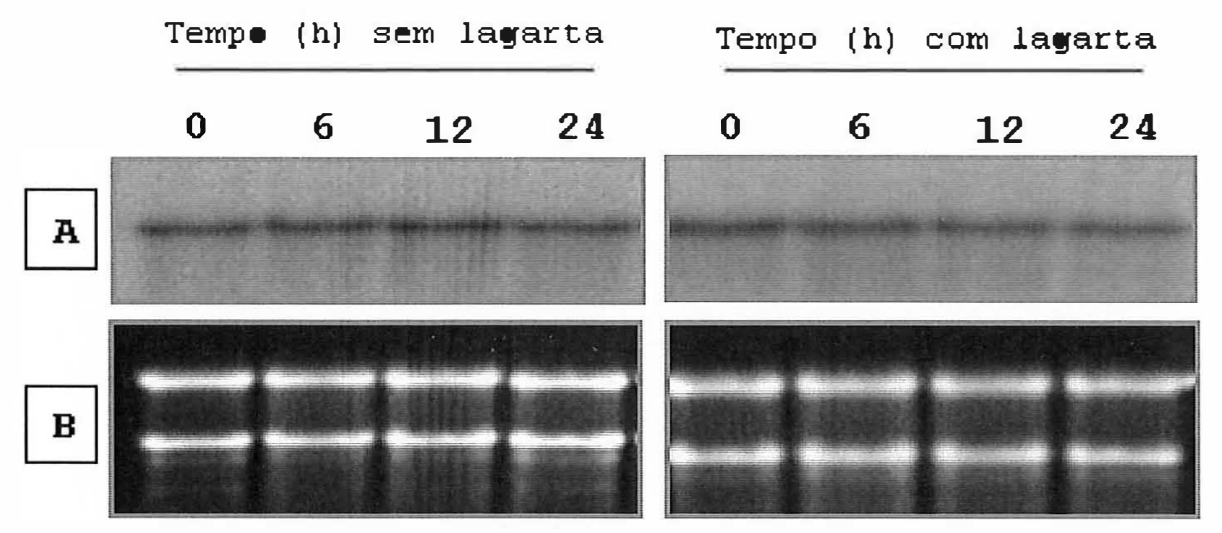

Figura 13 - Expressão do gene $\beta$-actina nos diferentes tempos (h) sem e com a presença de lagartas de $D$. saccharalis. $A=$ resultado do Northern Blot; $\mathrm{B}=$ controle de carregamento do RNA

\subsubsection{Gene LOX2 (lipoxigenase)}

A expressão do gene $L O X 2$ foi induzida nas plantas atacadas pelas lagartas, no entanto, com um padrão de expressão que aumentou gradativamente ao longo do tempo atingindo um pico entre 12 e 24 horas após o início do experimento.

As plantas controles (sem lagartas) também apresentaram este gene se expressando de maneira constitutiva, no entanto, em menor intensidade (Figuras 14 e 15). 

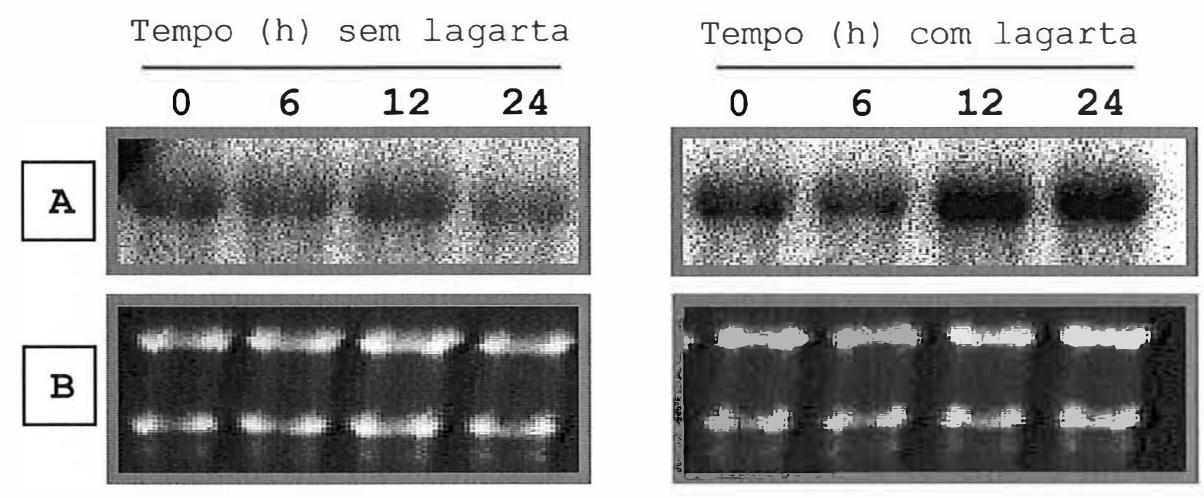

Figura 14 - Expressão do gene lipoxigenase (LOX2) nos diferentes tempos $(h)$ na ausência ou presença de lagartas de $D$. saccharalis. $A=$ resultado do Northern Blot; $B=$ controle de carregamento do RNA

Observando-se os resultados da quantificação da intensidade de expressão do gene LOX2 de cana-de-açúcar nos diferentes tempos (Tabela 5), nota-se que a expressão foi duplicada em relação ao controle no tempo de 24 horas com a presença da lagarta.

Tabela 5. Quantificação da intensidade de expressão do gene lipoxigenase (LOX2) de cana-de-açúcar nos diferentes tempos (h)

\begin{tabular}{llll}
\hline Tempo $(\mathrm{h})$ & Controle C & Tratamento $(\mathrm{T})$ & Razão (T/C) \\
\hline 0 & 5090,890 & 4494,590 & 0,883 \\
6 & 4145,670 & 3788,120 & 0,914 \\
12 & 4671,870 & 6139,130 & 1,314 \\
24 & 3070,590 & 6977,090 & 2,272 \\
\hline
\end{tabular}

Segundo Heitz (1997) o gene LOX está relacionado a via de sinalização induzida por ferimento.

Ryan (2000) mostrou em experimentos com plantas de tomate que, entre outros genes, a expressão do LOX foi detectada após 30 minutos. O pico máximo de expressão ocorreu entre 5-6 horas após o ferimento. 
Também essa cinética de indução foi observada em folhas de Arabidopsis cuja indução se iniciou 30 minutos após o dano e atingindo um pico entre $2-4$ horas (Laudert et al., 1996).

Segundo Reymond et al. (2000), o gene LOX2 está envolvido na síntese de membros da família jasmonato. Esses mesmos autores mostraram que 0 LOX2 é intesamente induzida tanto por dano mecânico quanto por dano provocado também por lagartas de $P$. rapae.

Bergey et al. (1996) classificaram a lipoxigenase como sendo uma classe de proteínas associadas a vias de sinalização.
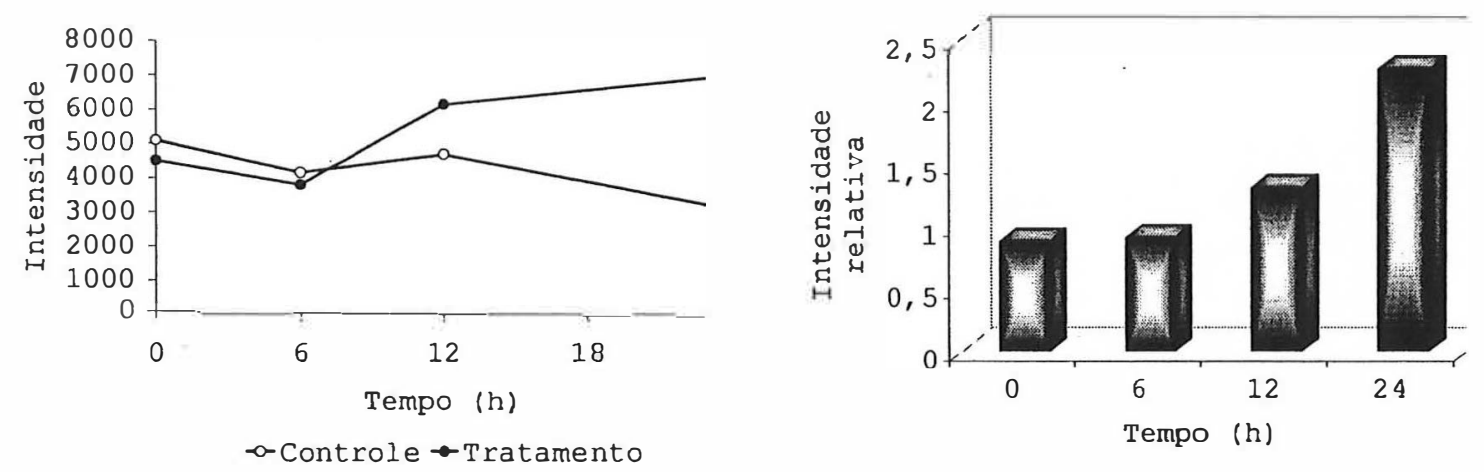

Figura 15 - llustração dos resultados de quantificação da intensidade de expressão do gene lipoxigenase (LOX2) de cana-de-açúcar nos diferentes tempos $(h)$

\subsubsection{Gene PPO (polifenol oxidase)}

O gene PPO apresentou indução logo após o início do ataque pelo inseto. Isto sugere que respostas diferenciais são observadas indicando que alguns genes se expressam mais rapidamente do que outros.

Aparentemente, no tempo 12 horas após o início do experimento ocorre o pico de expressão mas, ocorrendo no tempo 24 horas, um pequeno declínio (Figura 16). No entanto, pela quantificação (Tabela 6) e pela Figura 17 pode-se notar que em relação ao controle, na verdade, o pico ocorre no tempo 24 horas com a presença da lagarta. 

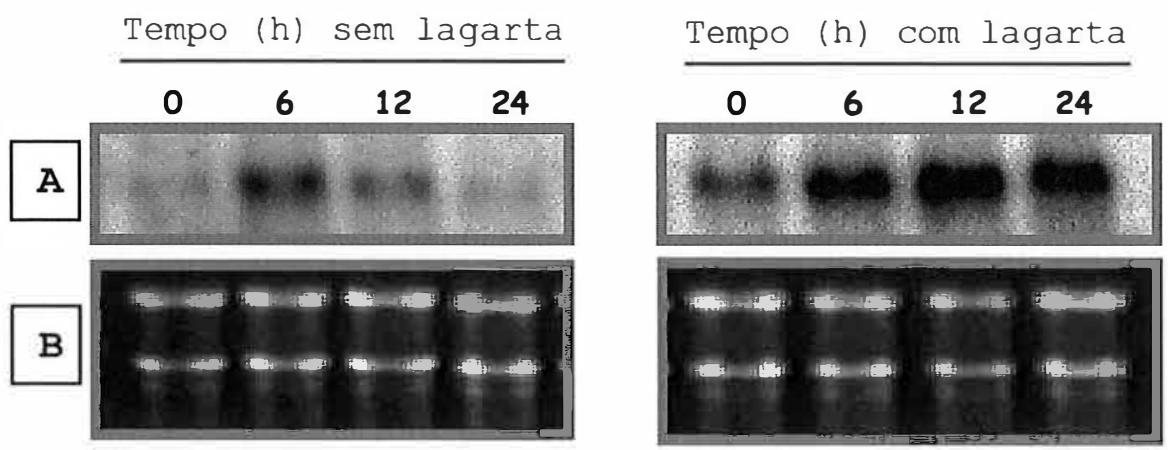

Figura 16 - Expressão do gene polifenol oxidase (PPO) nos diferentes tempos (h) na ausência ou na presença de lagartas de $D$. saccharalis. $A=$ resultado do Northern Blot; $\mathrm{B}=$ controle de carregamento do RNA

$\mathrm{Na}$ Tabela 6, onde estão apresentados os resultados da quantificação da intensidade de expressão do gene PPO de cana-de-açúcar nos diferentes tempos, observa-se um aumento de aproximadamente 10 vezes em relação ao controle (sem o ataque da lagarta) no tempo 24 horas.

Tabela 6. Quantificação da intensidade de expressão do gene polifenol oxidase (PPO) de cana-de-açúcar nos diferentes tempos (h)

\begin{tabular}{llll}
\hline Tempo $(\mathrm{h})$ & Controle C & Tratamento $(\mathrm{T})$ & Razão (T/C) \\
\hline 0 & 7202,480 & 11449,000 & 1,590 \\
6 & 31514,660 & 23295,710 & 0,739 \\
12 & 13369,360 & 24854,810 & 1,859 \\
24 & 3276,440 & 31755,120 & 9,692 \\
\hline
\end{tabular}



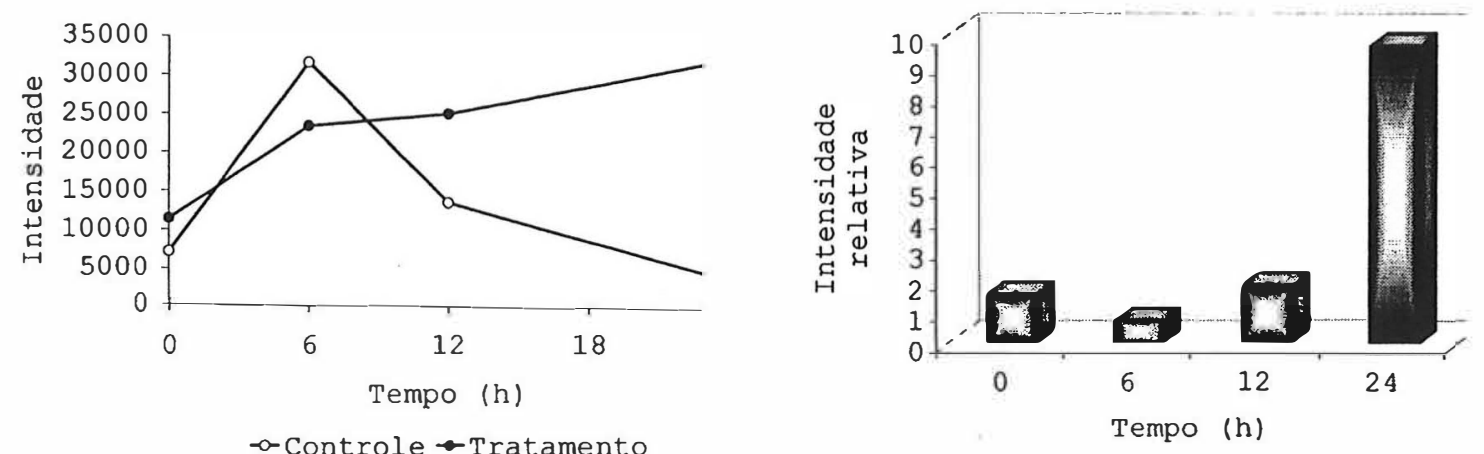

Figura 17 - llustração dos resultados de quantificação da intensidade de expressão do gene polifenol oxidase (PPO) de cana-de-açúcar nos diferentes tempos $(h)$

Embora estudos mostrem que o gene PPO esteja normalmente presente no reino vegetal, ele está envolvido no papel de defesa somente em poucas espécies (Constabel et al., 2000).

Diversos estudos demonstraram que o gene $P P O$ é induzido por ferimento em tomate, batata, maçã e álamo (Boss et. al., 1995; Thipyapong et al., 1995; Constabel et al., 2000).

Segundo Constabel et al. (2000), o PPO é induzido em folhas de álamo em resposta ao ataque de herbivoros e quando ingerido junto com os compostos fenólicos, pode ligar-se às proteínas afetando a digestão.

O PPO juntamente com inibidores de proteinase podem ser formidáveis barreiras para a digestão de proteínas em insetos (Ryan 2000).

Birkenmeier \& Ryan (1998) observaram que o PPO é fortemente induzido por sistemina e também por ferimento (Bergey et al., 1996).

Bergey et al. (1996) agrupa as PPO como proteínas de defesa.

\subsubsection{Gene cistatina (CIS)}

Para o gene $\mathrm{CIS}$ os resultados mostraram que ele também é induzido pelo ataque da broca (Figura 18), sendo maior a expressão 24 horas após a presença da broca na cana. 


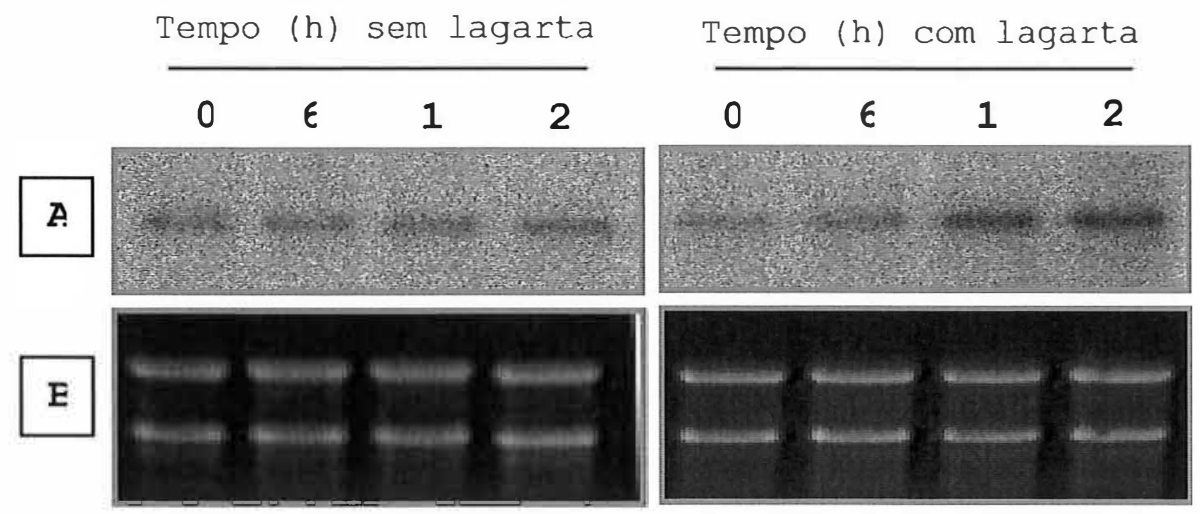

Figura 18 - Expressão do gene cistatina (CIS) nos diferentes tempos ( $h$ ) na ausência ou presença de lagartas de $D$. saccharalis. $A=$ resultado do Northern Blot; $\mathrm{B}=$ controle de carregamento do RNA

Pela quantificação da intensidade de expressão do gene CIS de cana-deaçúcar nos diferentes tempos (Tabela 7 ) pode-se dizer que o aumento foi de aproximadamente 5 vezes maior em relação ao controle no tempo 24 horas. Porém, nos demais tempos estudados a diferença na expressão foi pequena.

Tabela 7. Quantificação da intensidade de expressão do gene cistatina (CIS) de cana-de-açúcar nos diferentes tempos ( $h$ )

\begin{tabular}{llll}
\hline Tempo (h) & Controle C & Tratamento (T) & Razão (T/C) \\
\hline 0 & 4218,450 & 2094,000 & 0,496 \\
6 & 4346,860 & 1764,230 & 0,406 \\
12 & 4804,340 & 3910,750 & 0,814 \\
24 & 1607,950 & 9099,060 & 5,659 \\
\hline
\end{tabular}

O resultado da quantificação está ilustrado na Figura 19.

Pelos resultados apresentados nas Figuras 18 e 19 pode-se observar a maior expressão do gene CIS iniciando-se no tempo 12 horas e atingindo o máximo após 24 horas. O controle não apresentou alteração significativa em nenhum dos tempos estudados. 

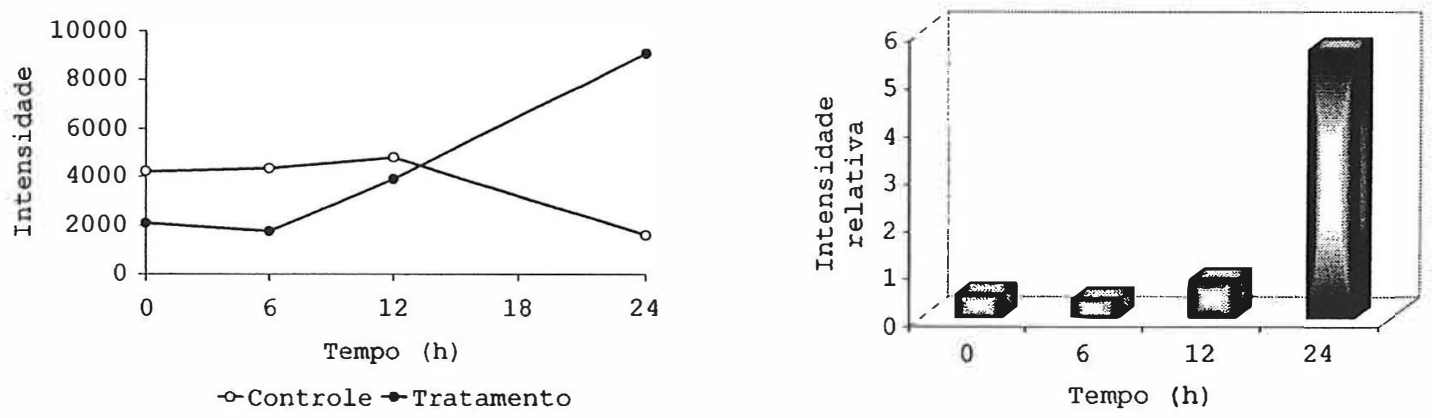

Figura 19 - llustração dos resultados de quantificação da intensidade de expressão do gene cistatina (CIS) de cana-de-açúcar nos diferentes tempos $(h)$

É amplamente conhecido que as fitocistatinas possuem papel de defesa em plantas devido aos efeitos sobre as proteinases exógenas, como as produzidas pelos insetos e nematóides (Zhao et al., 1996).

O envolvimento de fitocistatinas na defesa de plantas é sustentada por trabalhos mostrando que plantas transgênicas expressando-as têm aumento da resistência à herbivoros, bem como pelo fato delas serem induzidas em tomate por ferimento ou metil jasmonato (Botella et al. 1996).

Segundo Terra \& Ferreira (1994), de acordo com sua especificidade, as proteinases podem ser divididas em 4 classes: serina-proteinases, cisteinaproteinases, metalo-proteinases e aspartil-proteinase. Os inbidores de serina e cisteina proteinases são amplamente distribuídos nos tecidos de reserva das plantas, protegendo-os contra o ataque de patógenos e insetos e também servindo como proteína de reserva em sementes.

Os inibidores de proteinase são considerados antimetabólicos pois interferem no processo de digestão das proteínas, levando a redução dos aminoácidos disponíveis e desta forma afetando o desenvolvimento do inseto (Brodway \& Duffey, 1986).

Birkenmeier \& Ryan (1996) mostraram que assim como o PPO, o gene da CIS também é fortemente induzido por sistemina e foi agrupada por Bergey et al. (1996), como sendo também proteína de defesa. 


\subsubsection{Gene MT1 (metalotioneína)}

Os resultados do gene $M T 1$ mostraram que houve indução desse gene ao longo do tempo nas plantas atacadas pelas lagartas (Figuras 20 e 21), atingindo seu pico no tempo de 24 horas também.

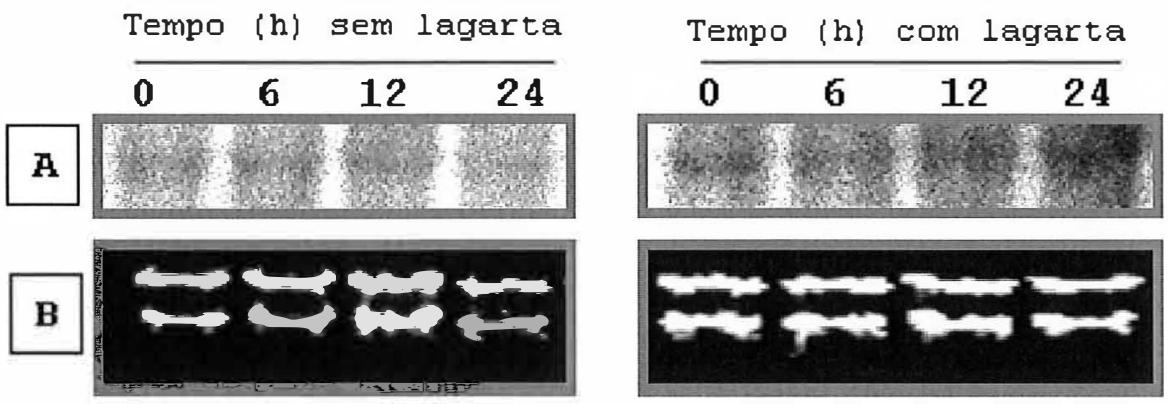

Figura 20 - Expressão do gene metalotioneína (MT1) nos diferentes tempos $(\mathrm{h})$ na ausência ou presença de lagartas de $D$. saccharalis. $A=$ resultado do Northern Blot; $\mathrm{B}=$ controle de carregamento do RNA

A quantificação da intensidade de expressão do gene MT1 de cana-deaçúcar nos diferentes tempos (Tabela 8 ) revela que a expressão é aproximadamente 3 vezes superior ao controle no pico de expressão.

Tabela 8. Quantificação da intensidade de expressão do gene metalotioneína (MT1) de cana-de-açúcar nos diferentes tempos (h)

\begin{tabular}{llll}
\hline Tempo $(\mathrm{h})$ & Controle C & Tratamento $(\mathrm{T})$ & Razão (T/C) \\
\hline 0 & 1425,180 & 2576,050 & 1,808 \\
6 & 1634,380 & 2583,380 & 1,581 \\
12 & 1845,380 & 3329,460 & 1,804 \\
24 & 1362,000 & 4448,350 & 3,266 \\
\hline
\end{tabular}

Reymond et al. (2000) analisaram a dinâmica e a regulação da expressão de 150 genes de Arabidopsis, entre eles o MT1. Os resultados 
mostraram que esse gene também é ativado em todos os tratamentos utilizados ou seja, nos ferimentos mecânico, por Pieris rapae e por desidratação.
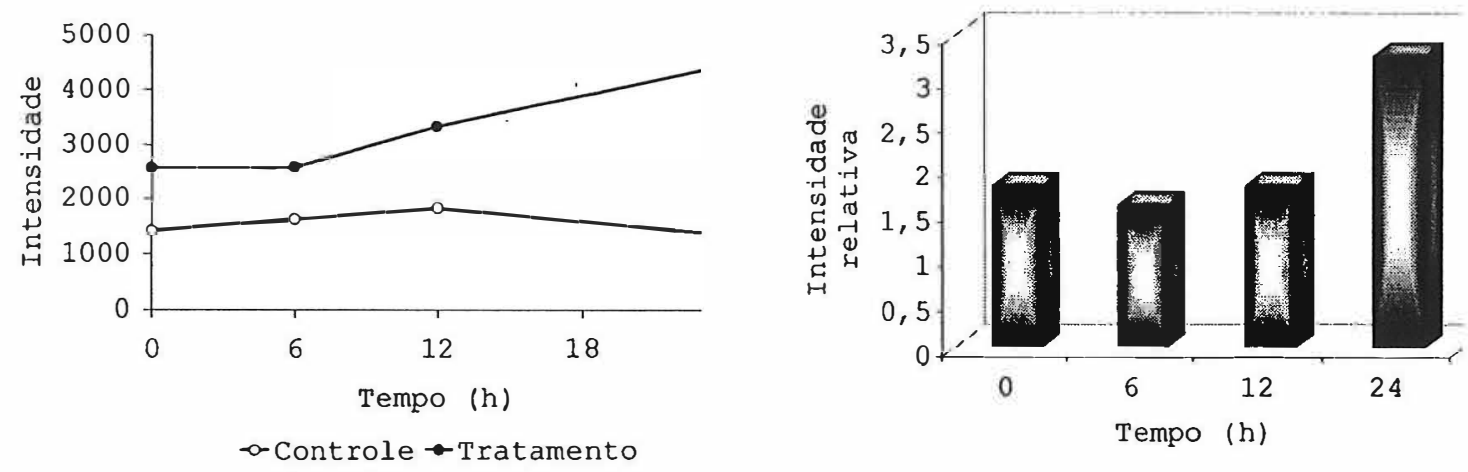

Figura 21 - llustração dos resultados de quantificação da intensidade de expressão do gene metalotioneína (MT1) de cana-de-açúcar nos diferentes tempos $(h)$

\subsubsection{Gene HEL (proteína tipo Heveína)}

No caso do gene HEL, observou-se que nas plantas não atacadas pela broca (controle) quase não houve sinal de indução, enquanto que nas plantas atacadas houve uma forte expressão no tempo de 24 horas após o início do experimento (Figura 22).

$\mathrm{Na}$ análise assistida por computador da expressão do gene HEL de cana-de-açúcar, a partir de bibliotecas de cDNA de diferentes tecidos, também não foi observada expressão desse gene na região utilizada para o Northern Blot (região do "colmo" próxima ao solo) (Figura 12), o que sugere fortemente que este gene seja ativado por insetos. 


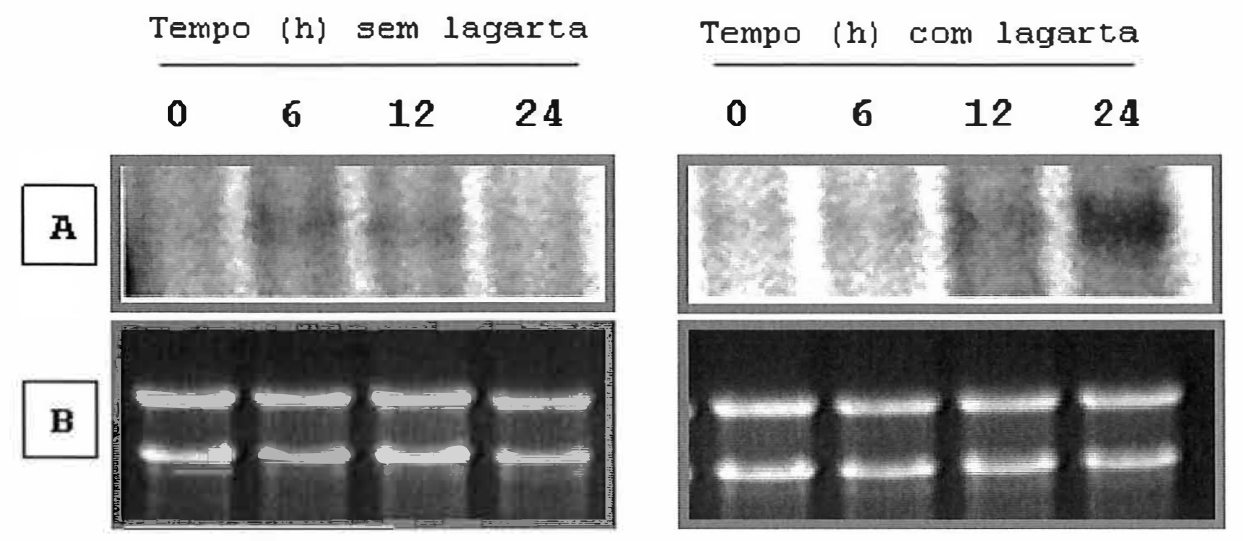

Figura 22 - Expressão do gene do tipo heveína (HEL) nos diferentes tempos (h) na ausência ou presença de lagartas de $D$. saccharalis. $A=$ resultado do Northern Blot; $\mathrm{B}=$ controle de carregamento do RNA

$\mathrm{Na}$ Tabela 9 nota-se que a expressão do gene HEL é aproximadamente 12 vezes superior ao controle, no tempo 24 horas.

Dos genes analisados, o HEL, foi o que apresentou maior indução em relação ao controle sendo, portanto, um candidato para o isolamento do promotor.

Além disso, Reymond et al. (2000) mostraram que o gene HEL foi o único dos 150 genes analisados em Arabidopsis induzido especificamente pelo ataque da lagarta $P$. rapae, tornando-se desta forma ainda mais interessante 0 isolamento do promotor desse gene, para o objetivo do presente trabalho.

Tabela 9. Quantificação da intensidade de expressão do gene do tipo heveína (HEL) de cana-de-açúcar nos diferentes tempos $(h)$

\begin{tabular}{llll}
\hline Tempo $(\mathrm{h})$ & Controle C & Tratamento $(\mathrm{T})$ & Razão $(\mathrm{T} / \mathrm{C})$ \\
\hline 0 & 3202,490 & 212,470 & 0,066 \\
6 & 4053,290 & 920,490 & 0,227 \\
12 & 2801,520 & 4386,500 & 1,566 \\
24 & 589,970 & 7412,730 & 12,565 \\
\hline
\end{tabular}


O resultado da quantificação está ilustrado na Figura 23.
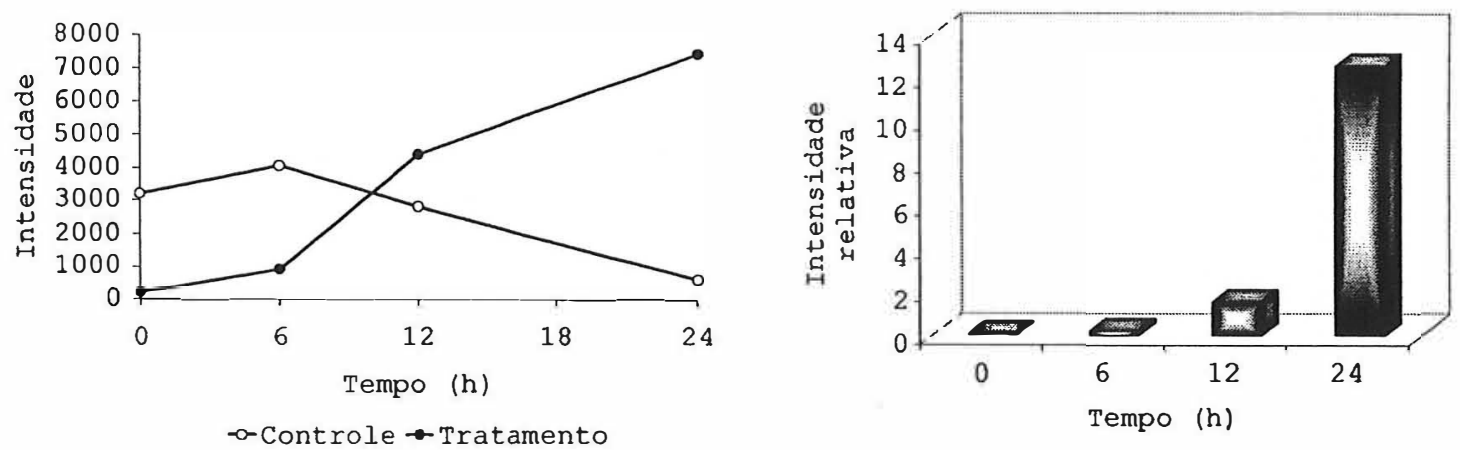

Figura 23 - llustração dos resultados de quantificação da intensidade de expressão do gene do tipo heveína (HEL) de cana-de-açúcar nos diferentes tempos $(\mathrm{h})$

Esses resultados indicam que a cana-de-açúcar, semelhantemente ao observado com outras espécies de plantas, induzem a expressão dos mesmos genes em resposta a herbivoria, embora haja uma variação clara entre genes que são rapidamente induzidos enquanto que outros são ativados numa resposta mais tardia.

A análise da expressão gênica em diferentes tempos revelou grupos de genes com comportamentos similares.

Uma implicação comum do padrão de expressão temporal é que genes talvez dividam papéis similares ou relacionados nos processos celulares, ou talvez sejam regulados pelas mesmas moléculas sinais (Reymond et al., 2000).

Cheong et al. (2002) separaram a expressão gênica após o dano em dois períodos de tempo. Aqueles genes com alteração significativa do nível de mRNA dentro de 30 minutos foram considerados genes de resposta inicial enquanto que, aqueles responsivos após 6 horas foram considerados de resposta tardia.

Comparando esses dois grupos de genes o autor observou dois fenômenos: 
-mais de $90 \%$ são genes de resposta inicial ou tardia e somente um pequeno número de genes (10\%) são pertencentes ao dois grupos. Isso indica que a indução da maioria dos genes de resposta inicial é transitória;

- o período de indução de um gene em particular por um sinal frequentemente reflete a posição do produto na via de resposta.

Por exemplo, genes de resposta inicial são freqüentemente aqueles que codificam componentes regulatórios ou de sinalização tais como as proteinas quinase e fatores de transcrição e os de resposta tardia são normalmente aqueles que codificam proteinas tais como as enzimas no metabolismo.

Em diversos casos, está claro que os produtos dos genes de resposta inicial regulam a expressão de genes tardios sugerindo uma cascata de regulação gênica (Cheong et al., 2002).

Dentre os genes citados como de resposta tardia por Cheong et al. (2002) estão os genes PR (relacionados a patogenese) e cuja HEL é homóloga a uma PR4 (Van Damme et al., 1999).

\subsection{Identificação e caracterização de promotores de genes de cana-de- açúcar induzidos por herbivoria}

\subsubsection{Identificação de promotores de genes de cana-de-açúcar induzidos por herbivoria}

A partir dos resultados obtidos no estudo da expressão gênica, apresentados no item 4.1.2, foram escolhidos os genes HEL e PPO para ser feita a clonagem da região promotora.

O gene do tipo heveína (HEL) apresentou forte indução no tempo 24 horas e o PPO apresentou indução gradativa ao longo do tempo atingindo um pico em 12 horas após o início do experimento, sendo que, nas plantas sem lagartas quase não houve expressão em ambos os genes. 
Inicialmente foi realizada uma avaliação dos iniciadores utilizados na técnica PCR-TAIL (Figura 24).

No PCR terciário são esperadas amplificações em diferentes níveis uma vez que os iniciadores específicos foram desenhados de forma a amplificarem fragmentos adjacentes, como pode ser observado nsa Figura 24 e 25.

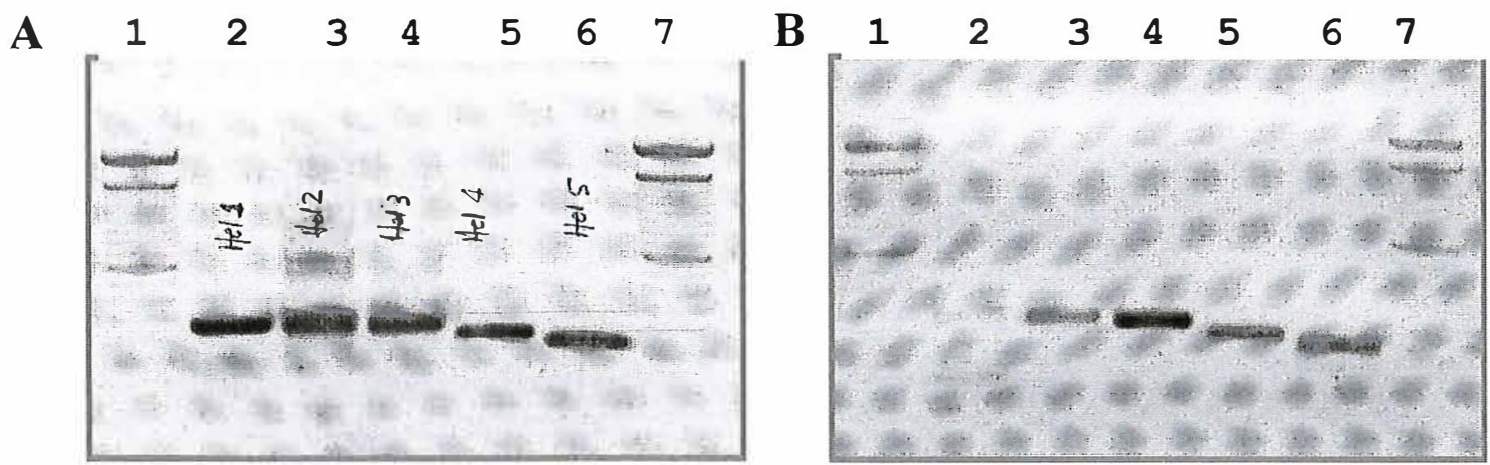

Figura 24 - Teste dos iniciadores desenhados para: (A) - o gene HEL (proteína do tipo heveína) e (B) - o gene PPO (polifenol oxidase) para verificação do resultado esperado na técnica PCR-TAIL. (A) Colunas 1 e $7=$ marcador de peso molecular $(100 \mathrm{pb})$ e colunas 2 , 3, 4, 5 e 6 iniciadores HEL1, 2, 3, 4 e 5 respectivamente. (B) Colunas 1 e $7=$ marcadores de peso molecular $(100 \mathrm{pb})$ e colunas 2, 3, 4, 5 e 6 iniciadores PPO1, 2, 3, 4 e 5 respectivamente

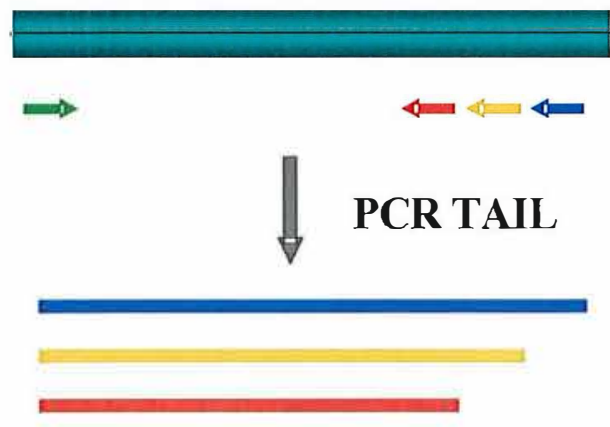

Figura 25 - Esquema de obtenção dos fragmentos de DNA via PCR-TAIL

\subsubsection{Primeira etapa}

Uma vez que os iniciadores específicos foram desenhados de forma a amplificarem fragmentos adjacentes, após inúmeras combinações de 
iniciadores obteve-se o resultado esperado, ou seja, amplificações em diferentes niveis tanto para o gene heveína (HEL) (Figura 26) quanto para 0 gene polifenol oxidase (PPO) (Figura 27), previamente selecionados.

O Fragmento maior amplificado em diferentes niveis para o gene HEL foi de aproximadamente 1100 pares de base com a combinação de iniciadores específicos HEL3, 4 e 5 e arbitrário AD2.

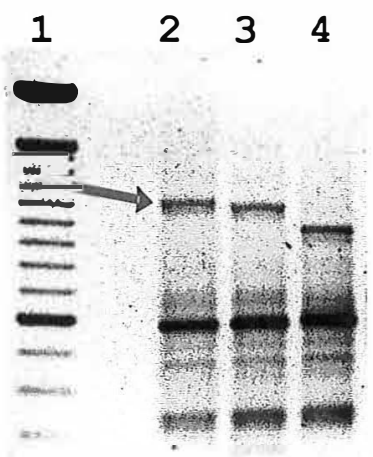

Figura 26 - Amplificações em diferentes níveis para o gene do tipo heveína (HEL). Coluna $1=$ marcador de peso molecular $(100 \mathrm{pb})$; colunas 2, 3 e 4 = amplificações utilizando as combinação de iniciadores específicos HEL3, 4 e 5 respectivamente com o arbitrário AD2

Para o gene $P P O$ o fragmento maior amplificado em diferentes níveis foi de aproximadamente 750 pares de base com a combinação de iniciadores específicos PPO3, 4 e 5 e arbitrário A5.

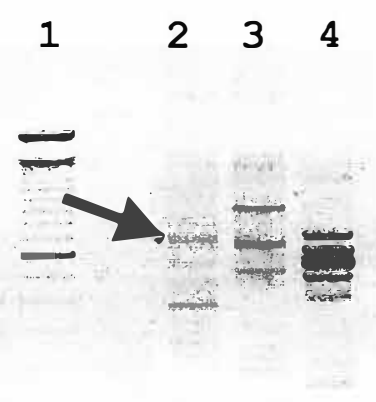

Figura 27 - Amplificações em diferentes níveis para o gene polifenol oxidase $(P P O)$. Coluna $1=$ marcador de peso molecular $(100 \mathrm{pb})$; colunas 2 , 3 e 4 = amplificações utilizando as combinação dos iniciadores específicos $\mathrm{PPO} 3,4$ e 5 respectivamente com o arbitrário A5 
Várias outras amplificações em diferentes niveis foram obtidas, no entanto, de menor tamanho e dessa forma desconsideradas.

Para realmente comprovar que esses fragmentos correspondiam à região promotora dos genes HEL e PPO de cana-de-açúcar e não à uma banda inespecífica, eles foram inicialmente clonados e, em seguida, seqüenciados.

\subsubsection{Gene PPO (polifenol oxidase)}

Na Figura 28 é apresentado o resultado do seguenciamento para o fragmento obtido por meio da técnica PCR-TAIL para o gene PPO.

GCGNNNNNNNGCNTTCCCCATACACTCACTATAGGGCGAȦTTTGGGCCCGACGTCGCAT NCTCCCGGCCGCCATGGCGGCCGCGGGAATTCGATTAGGGGTCTTGCCACAGGGATGCG AAGCGGCCTGAGCGGTGTGGCCGCCGGGCTCGCCTGGTACCCGGGCCTCGCGTCCGGAG CGGATTCGTCGTCTTCGCCGTGCACGACGGCGGACAAGGTGAACGAGAAGATCTTGCTG TGCGCGGACACGGACAAGCAGAAGCCCTGCCCTCTGGTGTCGCCGGCGGCCCCCGTGGA CTTCACGCCGGAAGGCAAGGTGACGCGCGTCCGGCAGCCCGTGCATCTCCTGAGCCGGG AATACCAGGAGAAGTACAAGGAGGCCGTCGGGAAGATGAAGGCGCTGCCGGAGTCGAAT CCGCTGAGCTTCAAGGCGCAGGCGGCCATCCACCAGGCTTACTGCGACAACTACTACAA GTACCACAAGTCATCCGGCTCGACGGTGGCCAAGGACGACCCGGCGTTCGACGTGCACT ACTCGTGGATCTTCGCGCCGTGGCACCGCATGTACATCTACTTCTACGAGCGTGCCCTC GGCGACCTCATCGGCGACAAAACCTTCGCGCTGCCGTTCTGGAGCTGGGACGCGCCGGC CGGCATGGTGGTACCGGCTCTCTTCAAGGAAGCCTTTGCCAACCCGCTGTACGACCCCA ACCGGAACACGGCGAACCTCAACGCGAATCACTAGTGAATTCGCGGCCGCCTGCAGGTC GACCATATGGGAGAGCTCCCAACGCGTTGGATGCATAGCTTGAGTATTCTATAGTGTCA ССTAAATAGCGGGGAAGTGGNNNTTTTTTTTTT. . . PPO

Figura 28 - Resultado do seguenciamento do fragmento obtido por meio da técnica PCR-TAlL para o gene PPO

Esta seqüência foi analisada inicialmente no banco de dados do SUCEST (FAPESP) e revelou-se ser uma polifenol oxidase (PPO). Em seguida foi feito um alinhamento dessa seqüência no banco de dados do NCBI e 
novamente revelou-se uma polifenol oxidase (PPO), como apresentado na Figura 29.

Dessa forma concluiu-se que o fragmento obtido por meio da técnica PCR-TAIL para o gene PPO completou o clone EST do SUCEST, que estava incompleto (Figura 30). Infelizmente, a seqüência obtida não apresentou a região regulatória, mas apenas a região 5'-UTR do gene em questão. 


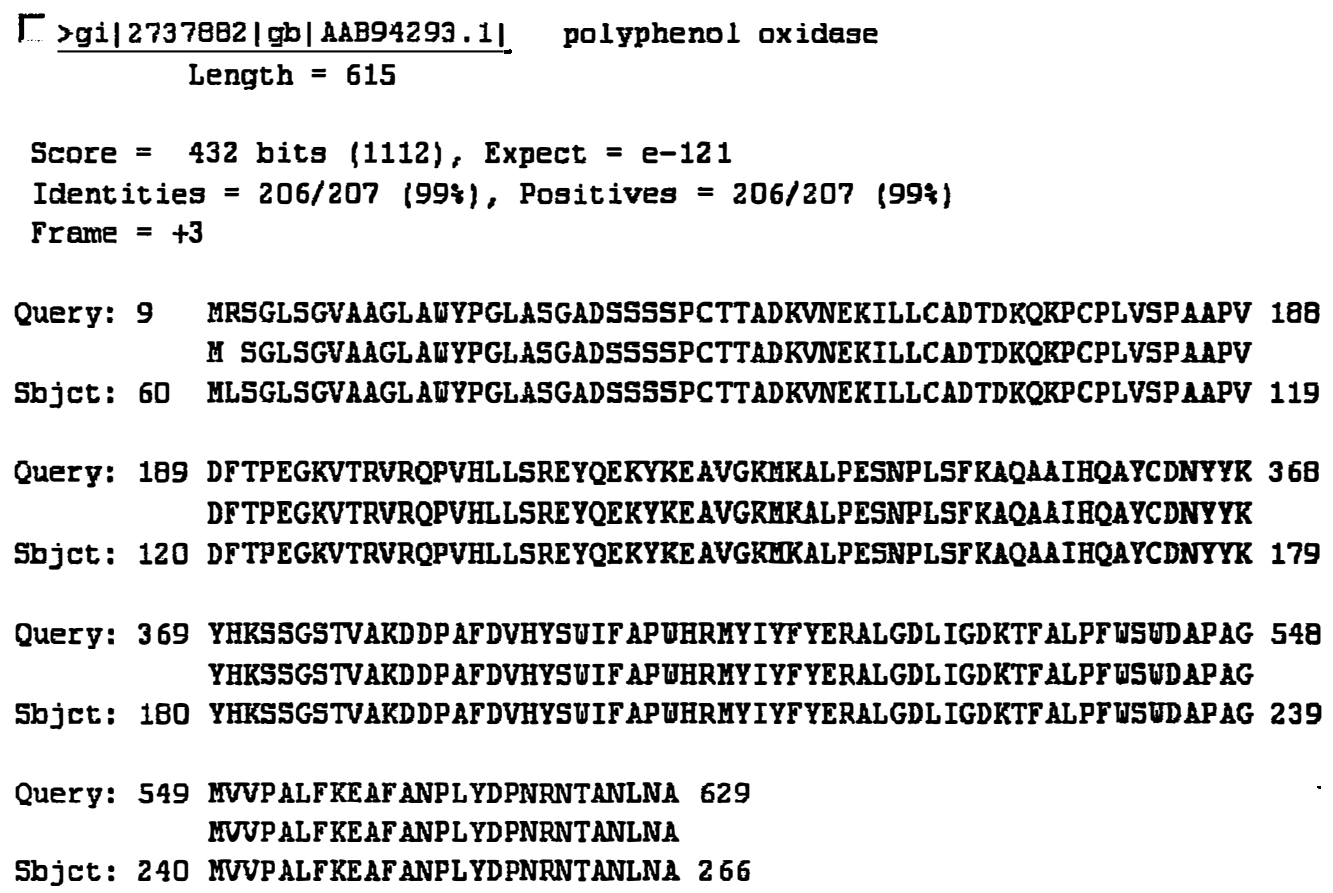

Figura 29 - (A) Resultado da comparação (blast) no banco de dados do NCBI utilizando o resultado obtido do sequenciamento do fragmento isolado para o gene PPO. (B) Resultado do alinhamento no banco de dados do NCBI com a seqüência do gene PPO de cana-deaçúcar 
Figura 30 - llustração do resultado obtido para o gene PPO

\subsection{Gene HEL}

Como o clone do HEL, obtido do SUCEST, estava completo (Figura 31) a região obtida provavelmente inclui pelo menos, parte da região regulatória do gene.

Portanto, para certificar que a seqüência proveniente do sequenciamento correspondia a uma região promotora e continha motivos regulatórios específicos, utilizou-se o programa disponivel na internet que destina-se para esse propósito. O programa forneceu como dados de saídas dezenas de motivos, dos quais alguns estão representados na Figura 32. 


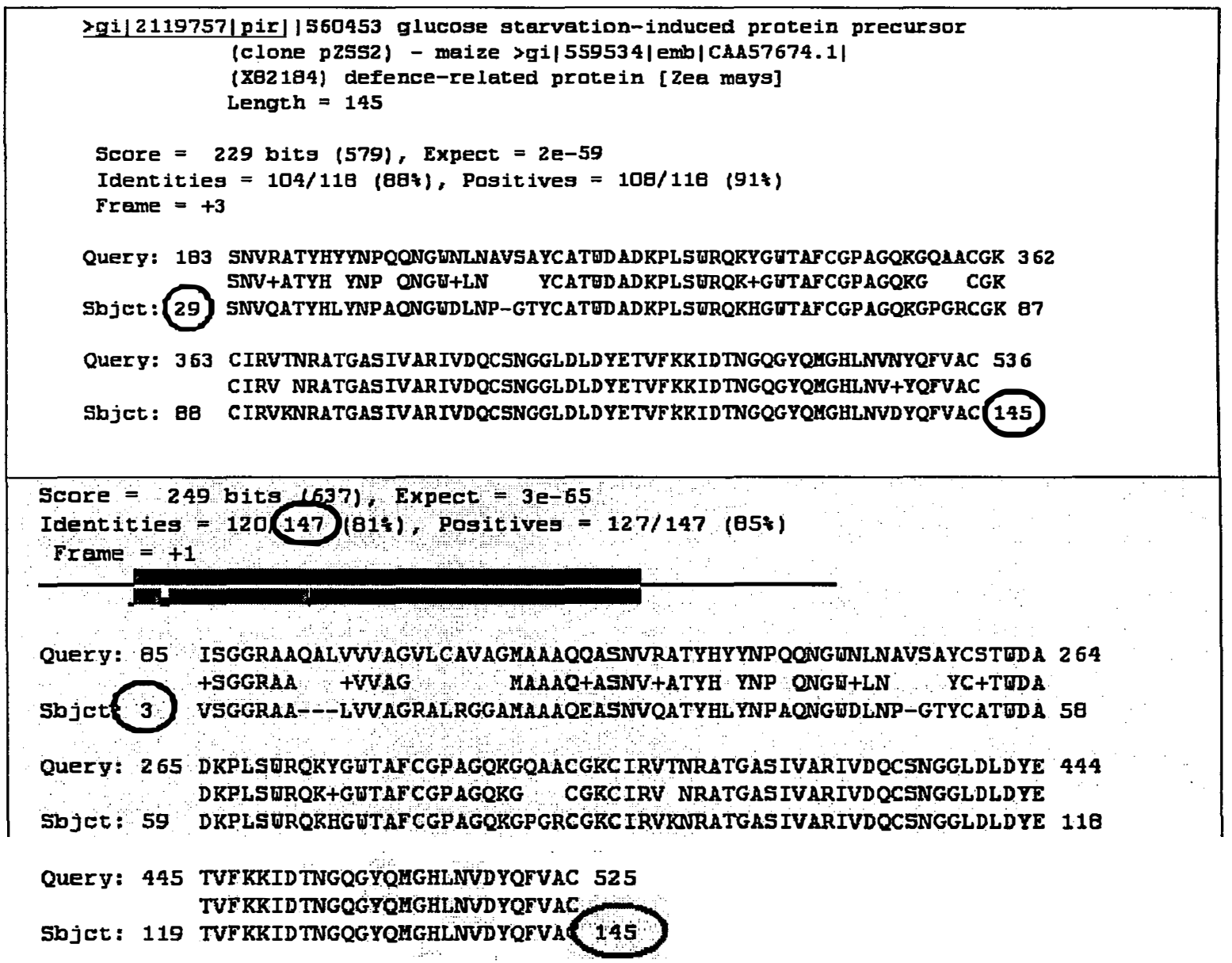

Figura 31 - (A) Resultado da comparação (blast) no banco de dados do SUCEST para o gene HEL. (B) Resultado do alinhamento no banco de dados do NCBI utilizando as informações obtidas no banco de dados do SUCEST 
NNNNNNNNGNNNNANNNNNNTNGCTTTGTATACGACTCACTATAGGGCGAATTGGGCCC GACGTCGCATGCTCCCGGCCGCCATGGCGGCCGCGGGAATTCGATTCGTCGAGTGAG Iniciador aleatório

AAGAACGAGAgTAGgGAAATGTTCTGCAGAAGTTGAAAAGCCCAAAGACCGGTTGCCT GGGCCGGTACGCAAGCCCAATAACCAAAGCGTCCTGACTCTATGTATTATTAACACGTG GTCGTCGTACTTGTCTACGGTGAGATCAAGGGATAAACCATACTTGCGCTCAGCTAGCA GGCGAAAAACCGTACTTATCTACCTTGCATAGGCAGCATGCATGGGCTATCTAGTGAgT AgTAGAGCTCGGACTTGGGCCGTGCTAтTTGAGGGCGGCTCTCATGGCACGGTCTTT TGCCACGATCTGAAGTATGGCACGGCACGAAATATTTTGGGTCGTACCGGCACGACACG CACACAAGGGCCGTGACGCTGTGCCGAGGATGTCGACACGACACGCACACGAGGGCC GTGCTTGGTCTGGCACGGCGGAAAAATGGCACGTANACACTTCTACAACTATACAATGC AATTNTTCTAGTATCTACTGTACTATTTCTCGTCTAATTCTTTAATAGATTATGAAAAT TATTAAACATTTCATTAAAATTAGTGCACACAAAAATATATATTTCATATCATGAgCGA AAAAAAAGGAAACTAGCAAATACATTTTGAGGGCCGTACTTGGACTGGCACGATCCGAA GACGTGCCAGCGTGCCACGGGCCATGTTTGGACCGAAGAAAAGATTCACCGTGCCATAT CGGTACGGCCCGACATGACGACCGTGCCTAGAGGGCACGTGAGTAGTAGTGTCTTCT GTCCTTGGAGAAAАTTCCACATCCTACGgCGCACCCAGACCTCTATATAATGCTAGC CTGTGATCTCCATCGAgGtAtAACGAACACACCCCACATTCGTCACTTGGTCTGCG TCACGTtAgGAgCGgCtCACAAgGtAAAAgCAAATCTCGCTACTCACGTTATCACACA TGCATGAGAGAATAAAGCTTAGCTTGCTGACATACATGCACGCAGGCAAAGGCAACAGT AAGAGGCAACTGACGATGGCGGCGGCAGCGATCTCCGGAGGACGGGCGgCAATCAC TAGTGAATTCGCGGCCGCCTGCAGGTCGACCATATGGGAGAGCTCCCAACGCGTTGGAT GCATAGCTTGAGTATTCTATAGTGTCACCTGATAGAAGGGAAGTNNNNNNCNCNNNNNN N . . HEL

Figura 32 - Resultado do sequenciamento do fragmento obtido por meio da técnica PCR-TAIL para o gene HEL. Em vermelho estão os possíveis motivos regulatórios 
A análise feita por meio do programa PLACE resultou em 56 motivos regulatórios na seqüência em estudo, incluindo resposta a stress, $A B A$, ácido salicílico, luz, auxina, temperatura, desidratação, etc . Desses 56 motivos 11 estão relacionados a algum tipo de estresse.

O motivo em cis mais característico encontrado na maior parte dos promotores é o TATA-BOX que em eucariotos está localizado a uma distância média de $32 \pm 7$ nucleotídeos do sítio de inicio da transcrição $(+1)$. 0 motivo TATA-BOX faz parte do que os biólogos moleculares denominam de core promoter (Butler \& Kadonaga, 2002; Rombauts, et al., 2003).

O core promoter, segundo Butler \& Kadonaga (2002), pode ser definido como a região mínima de seqüência de DNA que é suficientemente capaz de dirigir o processo de iniciação da transcrição pela maquinaria da RNA polimerase (expressão basal).

Geralmente, o core promoter engloba o sítio de início da transcrição e estende-se ou para esquerda ou para a direita em cerca de 35 nucleotídeos. Dessa forma, em muito exemplos, o core promoter compreende apenas 40 nucleotídeos (Butler \& Kadonaga, 2002).

O elemento responsivo ao etileno identificado como GCC Box (GCCGCC) é comumente encontrado em regiões promotoras de genes de defesa induzidos por etileno (Ohme-Takagi, 2000).

O GCC-box também é encontrado em muitos genes responsivos a patógenos, desempenhando papel importante na regulação da expressão de genes responsivos ao jasmonato (Brown et al., 2003).

O motivo ASF1 (TGACG) é um local de ligação em promotor $35 S$ de CaMV (cauliflower mosaic vírus). Os motivos TGACG são encontrados em muitos promotores e estão envolvidos com a ativação transcricional de diversos genes pela auxina e/ou ácido salicílico. Estresses biótico e abiótico estimulam diferentemente a atividade dos elementos "as-1" (Higo et al., 1999; Redman et al., 2002). 
O motivo AGC Box (AGCCGCC) é uma seqüência de ligação das proteínas AtERFs de Arabidopsis. As proteínas AtERF são fatores de sinais de resposta a estresse e são encontradas em promotor de tabaco. São conservados na maioria dos genes da proteína de defesa relacionada à patogênese - PR (pathogenesis related) (Higo et al., 1999).

Alguns desses motivos estão em destaque na Figura 32 e, estão apresentados na Tabela 10. Os detalhes podem ser obtidos acessando (http://uww.dna.affrc.go.jp/htdocs/PLACE/) e informando a seqüência apresentada na Figura 32.

Tabela 10. Alguns motivos encontrados no possível promotor do gene heveína (HEL), induzido por Diatraea saccharalis

\begin{tabular}{cccc}
\hline Nome do fator & Localização & Seqüência do fator & Site \\
\hline AGCBOXNPGLB & $385(-)$ & AGCCGCC & S000232 \\
ASF1MOTIFCAMV & $481(+)$ & TGACG & S000024 \\
ASF1MOTIFCAMV & $835(+)$ & TGACG & S000024 \\
ASF1MOTIFCAMV & $974(-)$ & TGACG & S000024 \\
ASF1MOTIFCAMV & $988(-)$ & TGACG & S000024 \\
GCCCORE & $77(+)$ & GCCGCC & S000430 \\
GCCCORE & $85(-)$ & GCCGCC & S000430 \\
GCCCORE & $385(-)$ & GCCGCC & S000430 \\
TATABOX4 & $920(+)$ & TATATAA & S000111 \\
\hline
\end{tabular}


Dessa forma concluiu-se que o fragmento obtido, por meio da técnica PCR-TAIL, para o gene HEL é provavelmente um fragmento do promotor (Figura 33).

PROMOTOR

$1100 \mathrm{pb}$
HEL

\section{ATG}

Figura 33 - llustração do resultado obtido para o gene HEL

No entanto, é preciso ter cautela. A presença de motivos numa região promotora não necessariamente implica em seqüências regulatórias. Provavelmente alguns dos vários motivos identificados podem ocorrer ao acaso.

\subsubsection{Segunda etapa}

Com base nos resultados para os genes PPO e HEL iniciou-se uma segunda etapa para obter o promotor do gene PPO e aumentar o fragmento do promotor do gene HEL.

Após a obtenção, na primeira etapa, de um primeiro fragmento tanto para o gene HEL quanto para o gene PPO, foram desenhados outros iniciadores específicos para ambos os genes a partir destes novos fragmentos (Figuras 34 e 35).

Foram repetidos todos os procedimentos da primeira etapa e, no entanto, não se obteve sucesso até o momento no isolamento de novas regiões promotoras. Assim novas combinações foram e serão testadas na tentativa de atingir os objetos para os genes HEL e PPO. 
NNNNNNNNGNNNNANNNNNNTNGCTTTGTATACGACTCACTATAGGGCGAATTGGGCCC GACGTCGCATGCTCCCGGCCGCCATGGCGGCCGCGGGAATTCGATTCGTCGAGTGAGAA Iniciador aleatório $\longleftarrow$ HEI 10

GAACGAGAGTAGGGAAATGTTCTGCAGAAGTTGAAAAGCCCAAAGACCGGTTGCCTGGG $\longleftarrow$ HEI 9

4 BEr 8 CCGGTACGCAAGCCCAATAACCAAAGCGTCCTGACTCTATGTATTATTAACACGTGGTC $\longleftarrow$ HEI 7 $\longleftarrow$ HEL 6 GTCGTACTTGTCTACGGTGAGATCAAGGGATAAACCATACTTGCGCTCAGCTAGCAGGC GAAAAACCGTACTTATCTACCTTGCATAGGCAGCATGCATGGGCTATCTAGTGAGTAGT AGAGCTCGGACTTGGGCCGTGCTATTTGAGGGCGGCTCTCATGGCACGGTCTTTTGCCA CGATCTGAAGTATGGCACGGCACGAAATATTTTGGGTCGTACCGGCACGACACGCACAC AAGGGCCGTGACGCTGTGCCGAGGATGTCGACACGACACGCACACGAGGGCCGTGCTTG GTCTGGCACGGCGGAAAAATGGCACGTANACACTTCTACAАCTATACAATGCAATTNTT CTAGTATCTACTGTACTATTTCTCGTCTAATTCTTTAATAGATTATGAAAATTATTAAA САTTTCATTAAAATTAGTGCACACAAAAATATATATTTCATATCATGAGCGAAAAAAAA GGAAACTAGCAAATACATTTTGAGGGCCGTACTTGGACTGGCACGATCCGAAGACGTGC CAGCGTGCCACGGGCCATGTTTGGACCGAAGAAAAGATTCACCGTGCCATATCGGTACG GCCCGACATGACGACCGTGCCTAGAGGGCACGTGAGTAGTAGTGTCTTCTGTCCTTGGA GAAAATTCCACATCCTACGGCGCACCCAGACCTCTATATAATGCTAGCCTGTGATCTCC ATCGAGGTATAACGAACACACCCCACATTCGTCACTTGGTCTGCGTCACGTTAGGAGCG GCTCACAAGGTAAAAGCAAATCTCGCTACTCACGTTATCACACATGCATGAGAGAATAA AGCTTAGCTTGCTGACATACATGCACGCAGGCAAAGGCAACAGTAAGAGGCAACTGACG ATGGCGGCGGCAGCGATCTCCGGAGGACGGGCGGCAATCACTAGTGAATTCGCGGCCGC CTGCAGGTCGACCATATGGGAGAGCTCCCAACGCGTTGGATGCATAGCTTGAGTATTCT ATAGTGTCACCTGATAGAAGGGAAGTNNNNNNCNCNNNNNNN . . . HEL

Figura 34 - Locais onde foram desenhados os novos iniciadores especificos para o gene HEL, com o objetivo de ampliar o fragmento do provável promotor obtido inicialmente 
GCGNNNNNNNGCNTTCCCCATACACTCACTATAGGGCGAATTTGGGCCCGACGTCGCAT

Iniciador aleatório NCTCCCGGCCGCCATGGCGGCCGCGGGAATTCGATTAGGGGTCTTGCCACAGGGATGCG $\longleftarrow$ PPO 10 $\leftarrow$ PPO 9

AAGCGGCCTGAGCGGTGTGGCCGCCGGGCTCGCCTGGTACCCGGGCCTCGCGTCCGGAG CGGATTCGTCGTCTTCGCCGTGCACGACGGCGGACAÄGTGAACGAGAAGATCTTGCTG TGCGCGGACACGGACAAGCAGAAGCCCTGCCCTCTGGTGTCGCCGGCGGCCCCCGTGGA CTTCACGCCGGAAGGCAAGGTGACGCGCGTCCGGCAGCCCGTGCATCTCCTGAGCCGGG AATACCAGGAGAAGTACAAGGAGGCCGTCGGGAAGATGAAGGCGCTGCCGGAGTCGAAT CCGCTGAGCTTCAAGGCGCAGGCGGCCATCCACCAGGCTTACTGCGACAACTACTACAA GTACCACAAGTCATCCGGCTCGACGGTGGCCAAGGACGACCCGGCGTTCGACGTGCACT ACTCGTGGATCTTCGCGCCGTGGCACCGCATGTACATCTACTTCTACGAGCGTGCCCTC GGCGACCTCATCGGCGACAAAACCTTCGCGCTGCCGTTCTGGAGCTGGGACGCGCCGGC CGGCATGGTGGTACCGGCTCTCTTCAAGGAAGCCTTTGCCAACCCGCTGTACGACCCCA ACCGGAACACGGCGAACCTCAACGCGAATCACTAGTGAATTCGCGGCCGCCTGCAGGTC GACCATATGGGAGAGCTCCCAACGCGTTGGATGCATAGCTTGAGTATTCTATAGTGTCA CCTAAATAGCGGGGAAGTGGNNNTTTTTTTTTT . . . PPO

Figura 35 - Locais onde foram desenhados os novos iniciadores específicos para o gene PPO, com o objetivo de obter um fragmento do promotor

\subsubsection{Caracterização do promotor induzido por ferimento}

A partir dos resultados obtidos para o gene do tipo heveina (HEL), foram feitas deleções a partir da extremidade 3' na provável região promotora a fim de determinar a presença de seqüências regulatórias, bem como do promotor mínimo. Para isso foram construidos iniciadores (Figura 36). 
NNNNNNNNGNNNNANNNNNNTNGCTTTGTATACGACTCACTATAGGGCGAATTGGGCCC GACGTCGCATGCTCCCGGCCGCCATGGCGGCCGCGGGAATTCGATTCGTCGAGTGAG Iniciador aleatório

AAGAACGAGAGTAGGGAAATGTTCTGCAGAAGTTGAAAAGCCCAAAGACCGGTTGCCT Iniciador B

GGGCCGGTACGCAAGCCCAATAACCAAAGCGTCCTGACTCTATGTATTATTAACACGTG GTCGTCGTACTTGTCTACGGTGAGATCAAGGGATAAACCATACTTGCGCTCAGCTAGCA GGCGAAAAACCGTACTTATCTACCTTGCATAGGCAGCATGCATGGGCTATCTAGTGAGT AGTAGAGCTCGGACTTGGGCCGTGCTATTTGAGGGCGGCTCTCATGGCACGGTCTTT TGCCACGATCTGAAGTATGGCACGGCACGAAATATTTTGGGTCGTACCGGCACGACACG CACACAAGGGCCGTGACGCTGTGCCGAGGATGTCGACACGACACGCACACGAGGGCC Iniciador $\mathrm{C} \rightarrow$ GTGCTTGGTCTGGCACGGCGGAAAAATGGCACGTANACACTTCTACAACTATACAATGC AATTNTTCTAGTATCTACTGTACTATTTCTCGTCTAATTCTTTAATAGATTATGAAAAT TATTAAACATTTCATTAAAATAgTGCACACAAAAATATATATTTCATATCATGAgCGA AAAAAAAGGAAACTAGCAAATACATTTTGAGGGCCGTACTTGGACTGGCACGATCCGAA GACGTGCCAGCGTGCCACGGGCCATGTTTGGACCGAAGAAAAGATTCACCGTGCCATAT CGGTACGGCCCGACATGACGACCGTGCCTAGAGGGCACGTGAGTAGTAGTGTCTTCT GTCCTTGGAGAAAATCCACATCCTACGGCGCACCCAGACCTCTATATAATGCTAGC Iniciador D CTGTGATCTCCATCGAgGTATAACGAACACACCCCACATTCGTCACTTGGTCTGCG TCACGTtAgGAgCGgCTCACAAgGTAAAAgCAAATCTCGCTACTCACGTTATCACACA TGCATGAGAGAATAAAGCTTAGCTTGCTGACATACATGCACGCAGGCAAAGGCAACAGT AAGAGGCAACTGACGATGGCGGCGGCAGCGATCTCCGGAGGACGGGCGGCAATCAC TAGTGAATTCGCGGCCGCCTGCAGGTCGACCATATGGGAGAGCTCCCAACGCGTTGGAT GCATAGCTTGAGTATTCTATAGTGTCACCTGATAGAAGGGAAGTNNNNNNCNCNNNNNN $\mathrm{N}$

Figura 36 - Locais na seqüência da provável região promotora do gene $H E L$ para serem feitas as deleções (indicados pelos iniciadores) e em vermelho os possiveis motivos regulatórios 
Nas deleções obteve-se três fragmentos que foram ligados ao vetor pCAMBIA $1281 Z$ para posterior transformação de calos de cana-de-açúcar (Figura 37):

- A-D com 211 pares de base;

- A-C com 600 pares de base;

- A-B com aproximadamente 1100 pares de base.
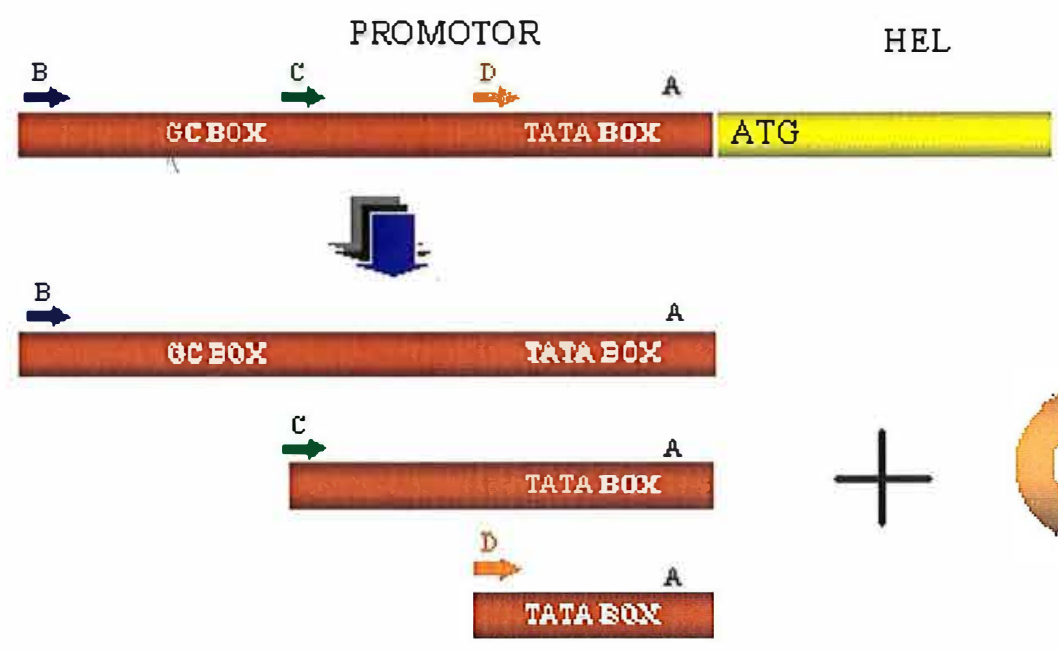

$\mathrm{pC} 12812$

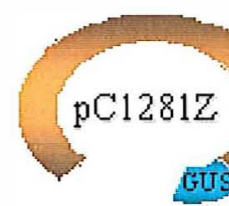

WANASOX

Figura 37 - llustração dos três fragmentos gerados pelas deleções no provável promotor do gene HEL e que foram ligados ao vetor pCAMBIA $1281 Z$ para posterior transformação de calos de cana-de-açúcar

Em seguida, utilizando como molde o DNA genômico da cana-de-açúcar, foram feitas amplificações por PCR com a enzima Pfx e os iniciadores $A+B$, $A+C$ e $A+D$, para posterior purificação do gel (Figura 38). 


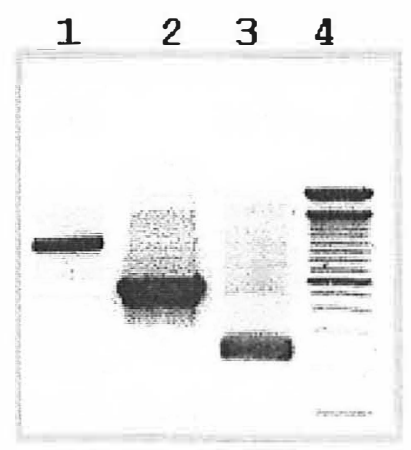

Figura 38 - Fragmentos amplificados por PCR utilizando os iniciadores desenhados na seqüência do provável promotor do gene $H E L$ (para as deleções). Coluna $1=$ iniciadores $A+B$ (aproximadamente 1100 pares de bases); coluna $2=$ iniciadores $A+C$ (aproximadamente 600 pares de bases); coluna $3=$ iniciadores $A+D$ (aproximadamente 211 pares de bases); coluna 4 = marcador de peso molecular (100 pares de base)

Os fragmentos obtidos foram utilizados na construção dos vetores para transformação de calos de cana-de-açúcar.

\subsubsection{Construção dos vetores para transformação}

Inicialmente os fragmentos do provável promotor do gene do tipo heveína (HEL) purificados do gel e o vetor pCAMBIA $1281 \mathrm{Z}$ foram digeridos com as enzimas de restrição $\mathrm{BamHI}$ e $\mathrm{Ncol}$ e purificados novamente (Figura 39).

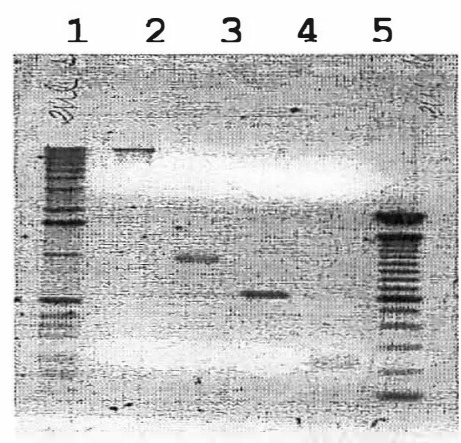

Figura 39 - Fragmentos do provável promotor do gene HEL e o vetor pCAMBIA 12812 purificados do gel e digeridos com as enzimas de restrição BamHI e Ncol. Colunas 1 e $6=$ marcadores de peso molecular $(1 \mathrm{~kb}$ e $100 \mathrm{pb}$

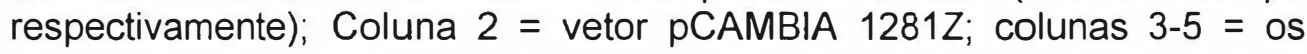
fragmentos de $\sim 1100$ pares de base, $\sim 600$ pares de base e $\sim 211$ pares de base respectivamente 
Após as reações de ligação dos fragmentos com o vetor pCAMBIA $1281 Z$ estas foram utilizadas para transformar células competentes de Escherichia coli. Os vetores tiveram suas seqüências confirmadas por seqüênciamento e em seguida utilizados na transformação genética da canade-açúcar.

\subsubsection{Transformação de plantas de cana-de-açúcar}

A seleção feita inicialmente por meio do antibiótico higromicina causou maior oxidação dos calos regenerados/plantas reduzindo o número e qualidade de plantas obtidas da transformação. Dessa forma optou-se por utilizar cotransformação com seleção feita com o antibiótico geneticina (Figura 40).
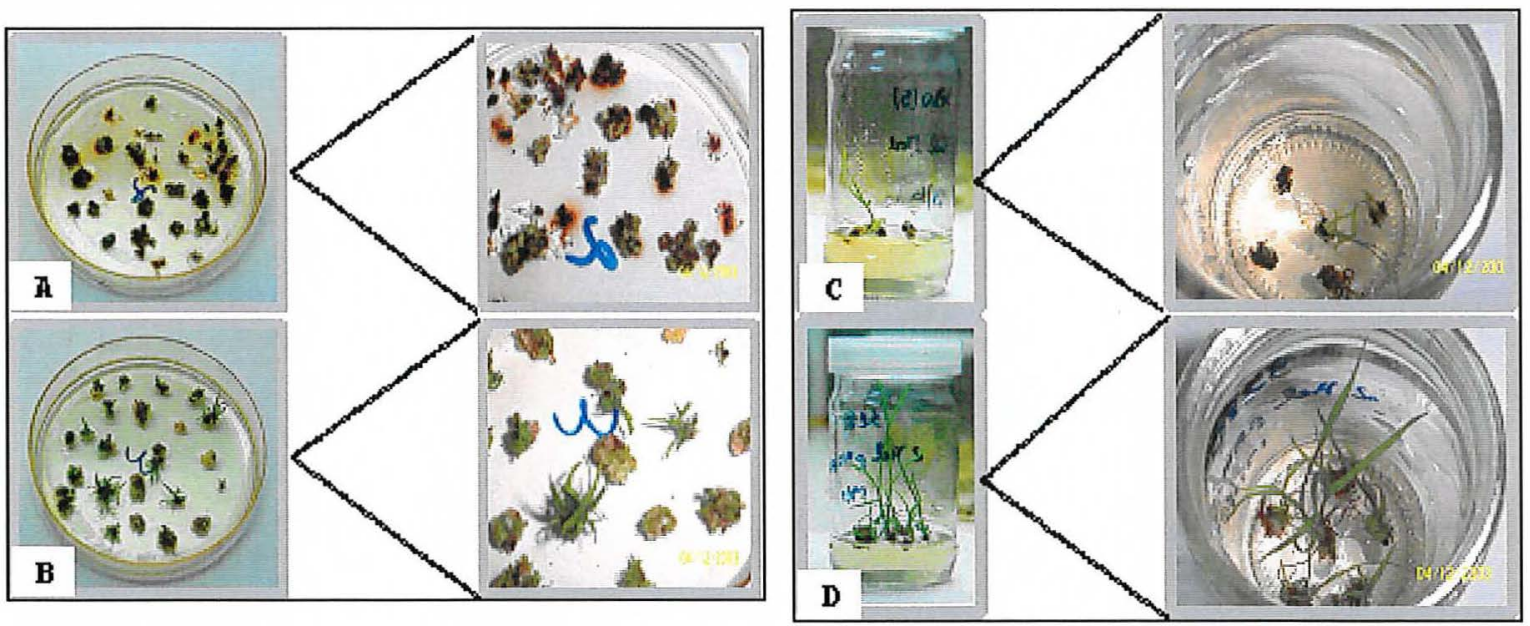

Figura 40 - Calos de cana-de-açúcar sendo selecionados em meio de cultura contendo o antibiótico higromicina (A) e o antibiótico geneticina (B). Plantas de cana-de-açúcar em fase de enraizamento em meio contendo higromicina e (C) contendo geneticina (D)

Foram obtidas dezenas de plantas, em todos os estágios de desenvolvimento, já transformadas com o provável promotor induzido por herbivoria, do gene do tipo heveína (HEL) (Figura 41). 


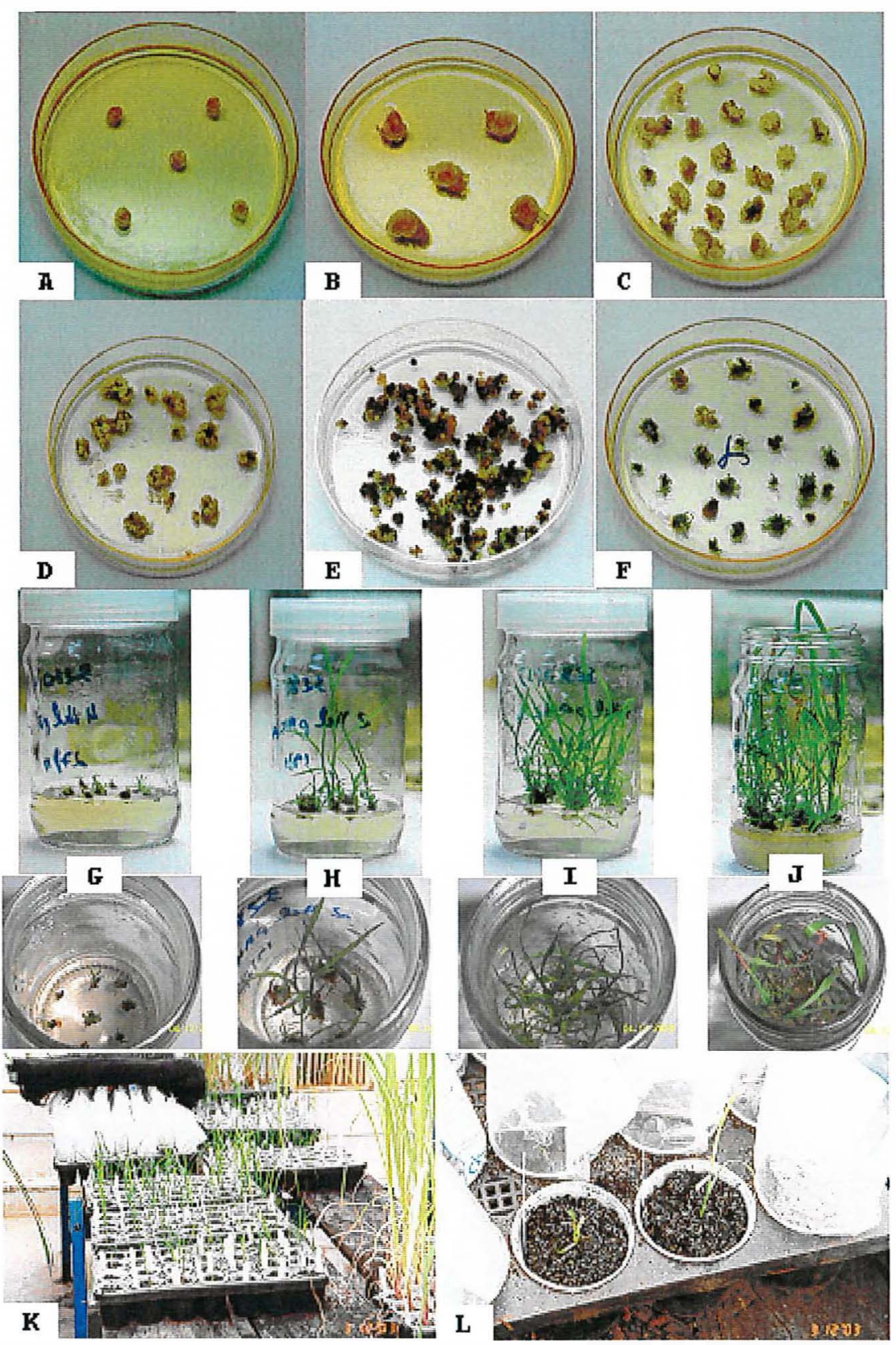

Figura 41 - Diferentes fases de desenvolvimento das plantas de cana-deaçúcar transformadas. (A) Folha jovem picada; (B) Calos em formação; (C) calos isolados; (D) Seleção de calos na fase sem luz; (E) Seleção de calos na fase com luz; (F) Seleção de calos regenerando; ( $G$ - J) fase de enraizamento; $(K-L)$ Fase de aclimatação das supostas plantas transgênicas contendo 0 possível promotor induzido do gene HEL 


\subsubsection{Identificação de plantas de cana-de-açúcar transgênicas por reação em cadeia da polimerase (PCR)}

Os resultados dos testes realizados por meio de PCR para identificação das plantas de cana-de-açúcar transformadas estão apresentados na Figura 42, para posterior estudo do promotor.

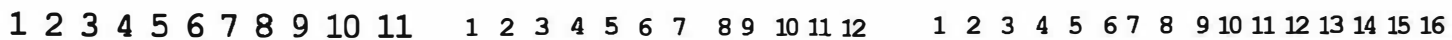

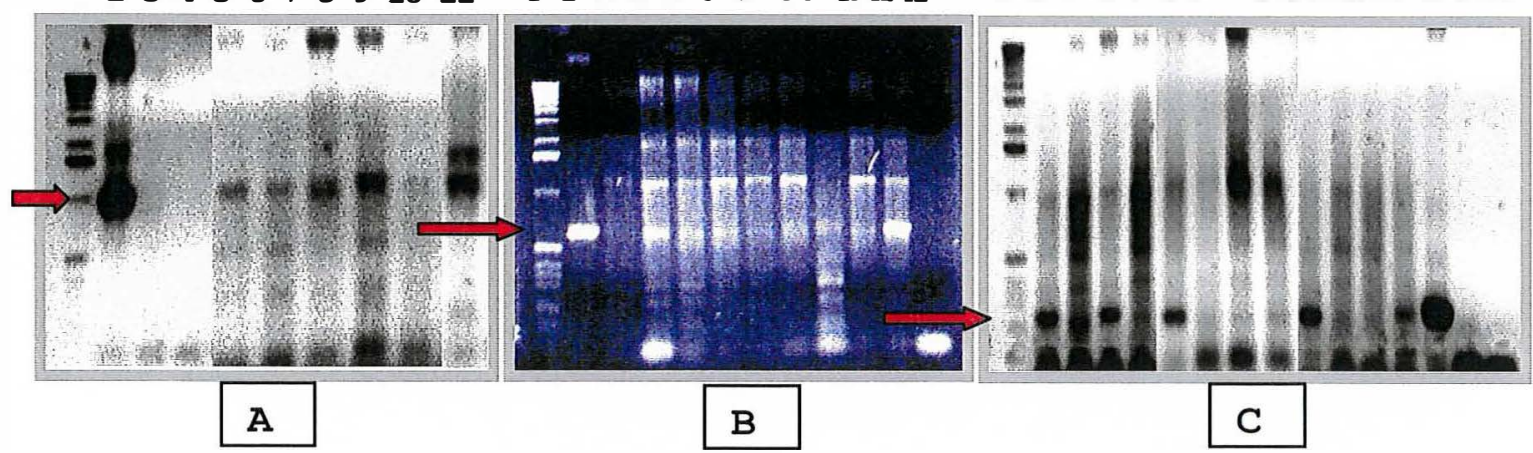

Figura 42 - Análise das plantas transgênicas de cana-de-açúcar. (A) amplificações do fragmento A-B ( 1100 pares de base $)$. Coluna $1=$ marcador de peso molecular $(1 \mathrm{~kb})$; coluna 2 = controle positivo (vetor pCAMBIA contendo o fragmento $A-B$ ); colunas 3 e $4=$ controles negativos (planta não transformada e água respectivamente); colunas $5-11=$ plantas transgênicas. (B) amplificações do fragmento A-C ( 600 pares de base). Coluna $1=$ marcador de peso molecular $(1 \mathrm{~kb})$; coluna $2=$ controle positivo (vetor pCAMBIA contendo o fragmento $\mathrm{A}-\mathrm{C}$ ); colunas 3 e $12=$ controles negativos (planta não transformada e água respectivamente); colunas 4-11 = plantas transgênicas. (C) amplificações do fragmento A-D ( 211 pares de base). Coluna $1=$ marcador de peso molecular $(1 \mathrm{~kb})$; coluna $14=$ controle positivo (vetor pCAMBIA contendo o fragmento A-D); colunas 15 e $16=$ controles negativos (planta não transformada e água respectivamente); colunas 2-13 = plantas transgênicas 


\subsubsection{Análise molecular dos promotores}

\subsubsection{Expressão transiente em células epidérmica de cebola}

Os ensaios preliminares de expressão transiente em células epidérmicas de cebola revelaram atividade da enzima $\beta$-glucuronidase (GUS) no controle positivo (vetor 1301) e também na construção maior (A-B) do possivel promotor induzido, utilizando o vetor pCAMBIA 1281Z. Já no controle negativo não foi observada a atividade da enzima GUS (Figura 43).

A reação positiva da GUS observada nas células da epiderme de cebola aparecem concentrados preferencialmente na região central da célula ou na forma de muitos cristais acirculares dispersos.

Este mesmo tipo de expressão do gene repórter uidA (gene codante da enzima $\beta$-glucuronidase) foi observado em células de embriões eletroporados de Vigna unguiculata Walp, nas quais o produto da reação da enzima $\beta$ glucuronidase com o substrato $x$-gluc apresenta-se como cristais azuis localizados em todos os tipos celulares (Akella \& Lurquin, 1993).

O teste histoquímico revelou que há elementos regulatórios que permitiram a expressão da proteína GUS em um sistema de expressão heterólogo (Figura 43).

Portanto, a região de 1100 pares de base clonada possui elementos regulatórios capazes de dirigir a expressão de um gene repórter.

Entretanto, é difícil determinar se todos os elementos regulatórios presentes na região promotora do gene do tipo heveína (HEL) estão presentes, visto que enhancers podem estar localizados a milhares de pares de bases a montante do ponto inicial da transcrição (Butler \& Kadonaga, 2002).

A expressão obtida com o vetor 35S-GUS e a ausência de expressão com o vetor pCAMBIA $1281 Z$ indicam que os dados obtidos com a construção A-B sejam resultado do promotor do HEL. 


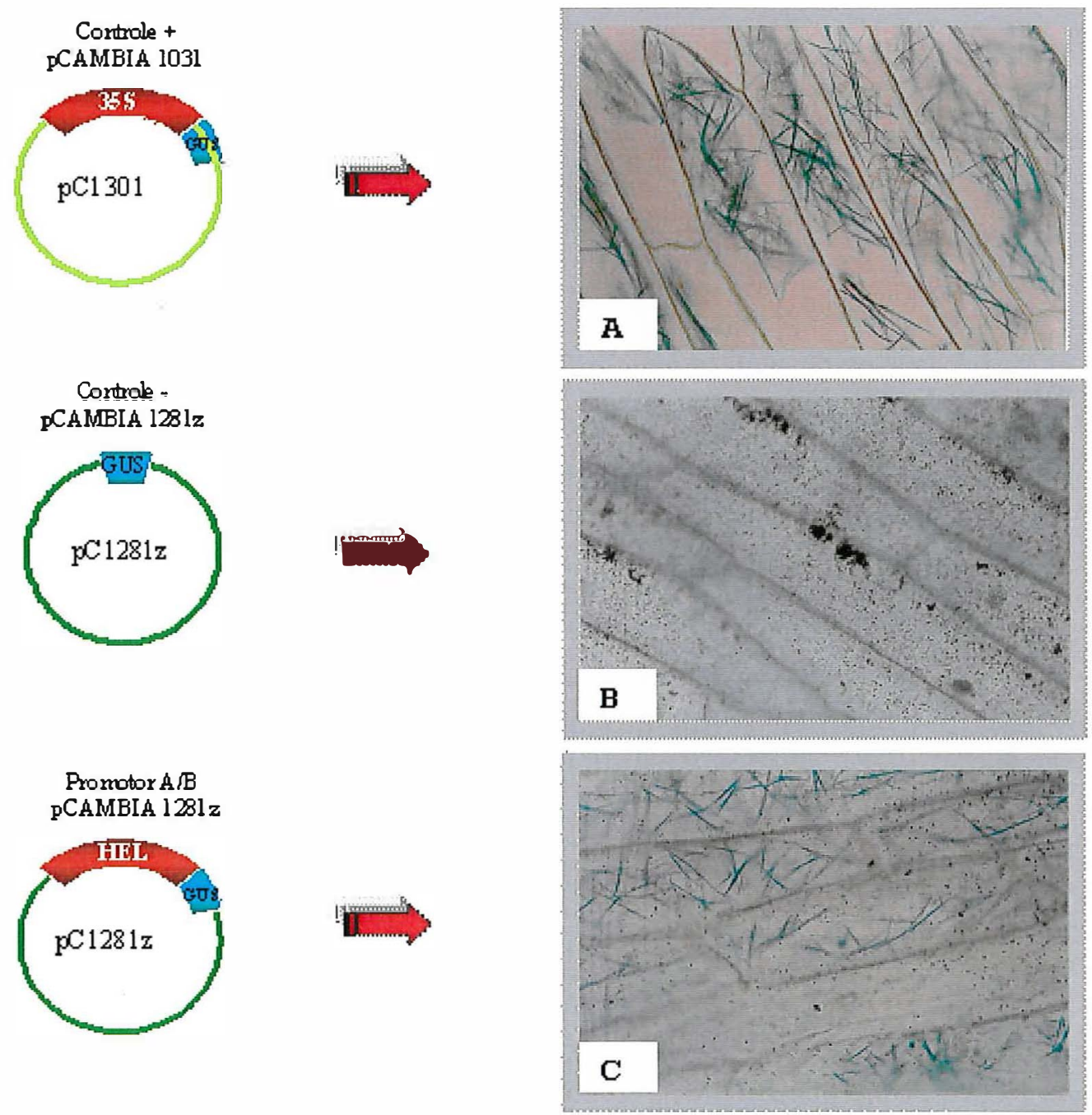

Figura 43 - Deteç̧ão da atividade da GUS pelo ensaio histoquímico. Expressão transiente em células epidérmicas de cebola após transformação por biobalística com os vetores (A) controle positivo (vetor pCAMBIA 1301); (B) controle negativo (vetor pCAMBIA 1281Z); (C) pCAMBIA $1281 \mathrm{z}$ +fragmento $\mathrm{A}-\mathrm{B}(\sim 1100$ pares de base)

\subsubsection{Regulação por herbivoria}

As plantas transformadas utilizadas nos ensaios de herbivoria apresentaram danos predominantemente na região próxima ao solo (Figura 44). Foram isoladas as regiões próximas ao dano, palmito, folha e raiz para os ensaios histoquímico e fluorimétrico da enzima ß-glucuronidase (GUS). 


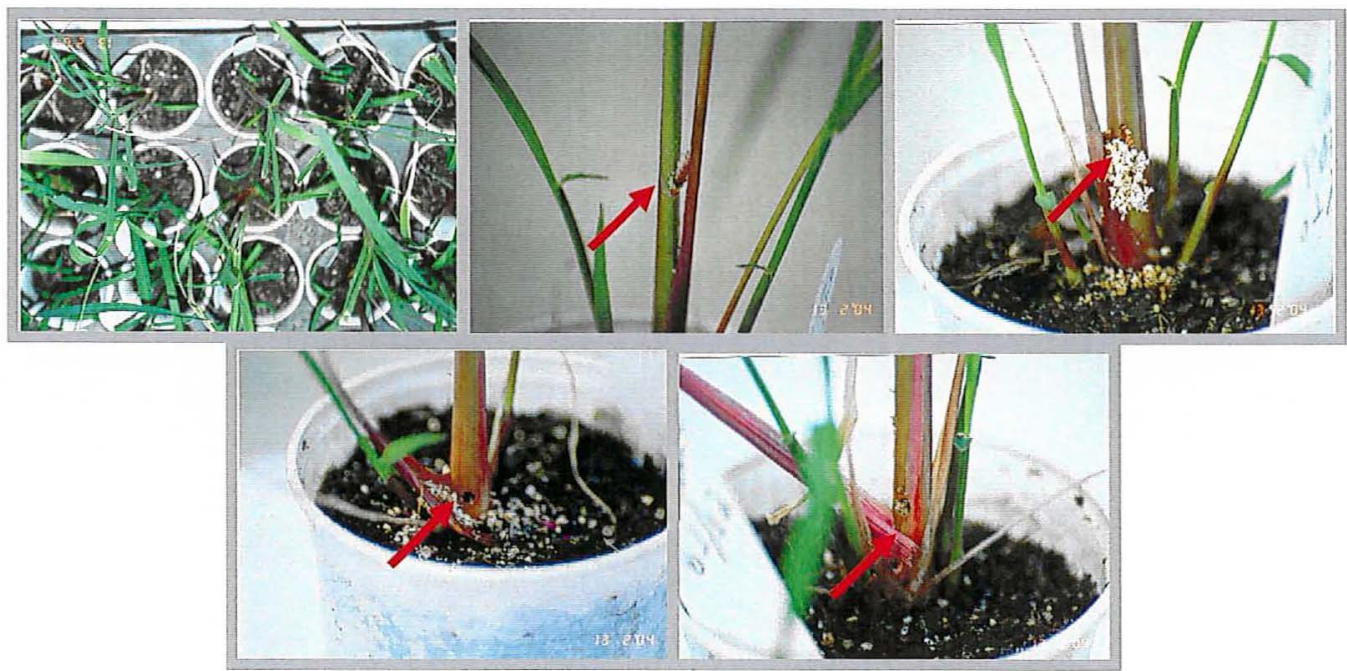

Figura 44 - Plantas de cana-de-açúcar, transformadas, utilizadas nos ensaios de herbivoria (broca da cana). Observa-se pela indicação das setas, o predomínio dos danos na região próxima ao solo

\subsubsection{Ensaio histoquímico e fluorimétrico da enzima ß-glucuronidase} (GUS)

A fim de verificar a existência de uma interação entre regulação tecidoespecífica e resposta à lagarta, foram analisados diferentes tecidos (folhas, "palmito", região próxima ao dano e raízes) das plantas pertencentes às construções gênicas $A-B, A-C$ e $A-D$. Para isso a enzima B-glucuronidase (GUS) foi analisada quanto sua presença por meio de ensaios histoquímicos e quantificada pelo método fluorimétrico.

\subsection{Ensaio histoquímico}

Os resultados dos ensaios histoquímicos mostraram que o tecido próximo ao dano respondeu (aumento da expressão GUS) positivamente e em maior dimensão ao ataque da broca da cana, quando comparado aos tecidos que estavam mais distantes. A regulação positiva gerada pela presença das lagartas de Diatraea saccharalis pode estar associada ao papel de defesa desempenhado pelo gene HEL. 
Observa-se também que não houve a expressão da GUS no controle negativo. Portanto, a atividade GUS proveniente das construções gênicas ( $A-B$, $A-C$ e $A-D$ ) baseadas na região regulatória isolada do gene $H E L$ indica que este gene é regulado por herbivoria. A atividade GUS também foi observada nos controles positivos: vetores pCAMBIA 1302 e pAHC27 (Figuras 45, 46, 47 e 48).

Pelos resultados obtidos nos ensaios histoquímicos, na construção gênica A-C (de $~ 600$ pares de base) pode-se especular que a resposta ao ataque das lagartas de $D$. saccharalis pode ser sistêmica, ou seja, a planta toda responde ao ataque da praga, uma vez que se observa coloração azul na região da raiz também, de umas das plantas analisadas. 


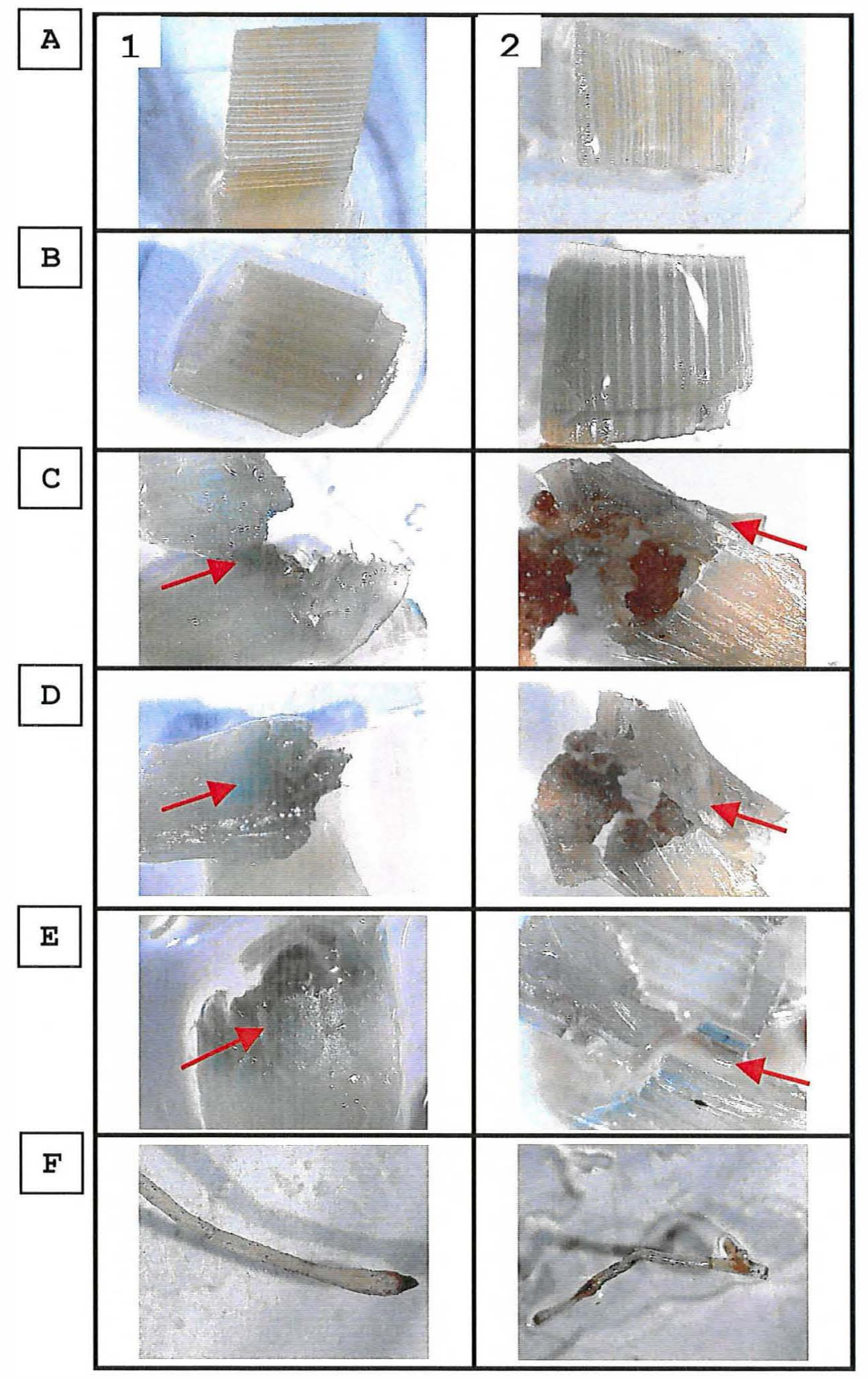

Figura 45 - Detecção da atividade da GUS, realizada pelo ensaio histoquímico, em diferentes partes das plantas transgênicas de cana-de-açúcar contendo a construção gênica pCAMBIA $1281 z$ + fragmento $A-B$, expostas ao ataque de lagartas de Diatraea saccharalis. $(1)=$ planta $1 ; 2=$ planta 2 . $(\mathrm{A})=$ porção da folha; (B) = porção do "palmito"; (C), (D) e (E) = local do dano (porção próxima ao solo); $(\mathbf{F})=$ porção da raiz 


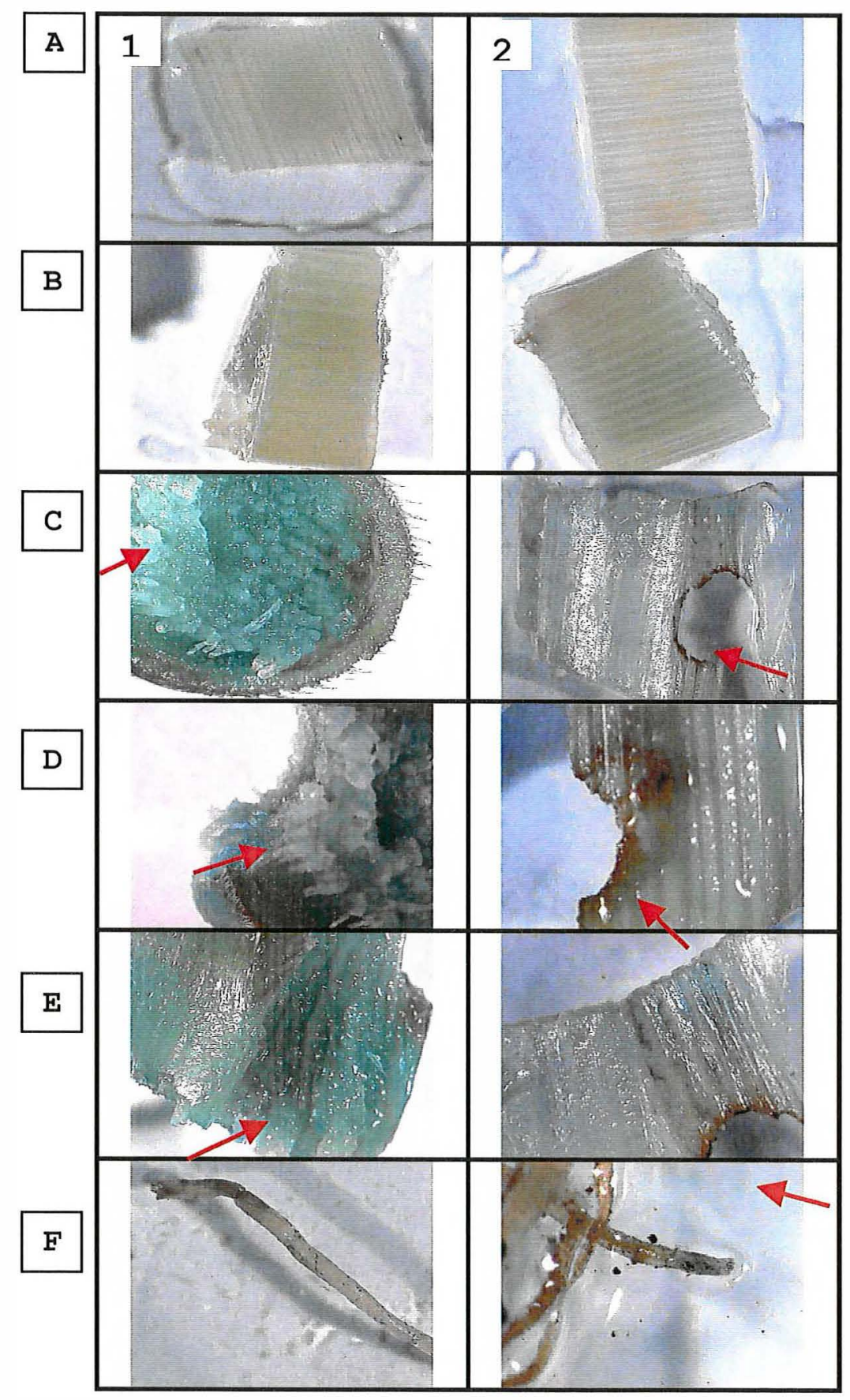

Figura 46 - Detecção da atividade da GUS, realizada pelo ensaio histoquímico, em diferentes partes das plantas transgênicas de cana-de-açúcar contendo a construção gênica pCAMBIA $1281 z$ + fragmento A-C expostas ao ataque de lagartas de Diatraea saccharalis. $(\mathbf{1})=$ planta $1 ; 2=$ planta 2 . $(\mathbf{A})=$ porção da folha; (B) = porção do "palmito"; (C), (D) e (E) = local do dano (porção próxima ao solo); $(\mathbf{F})=$ porção da raiz 


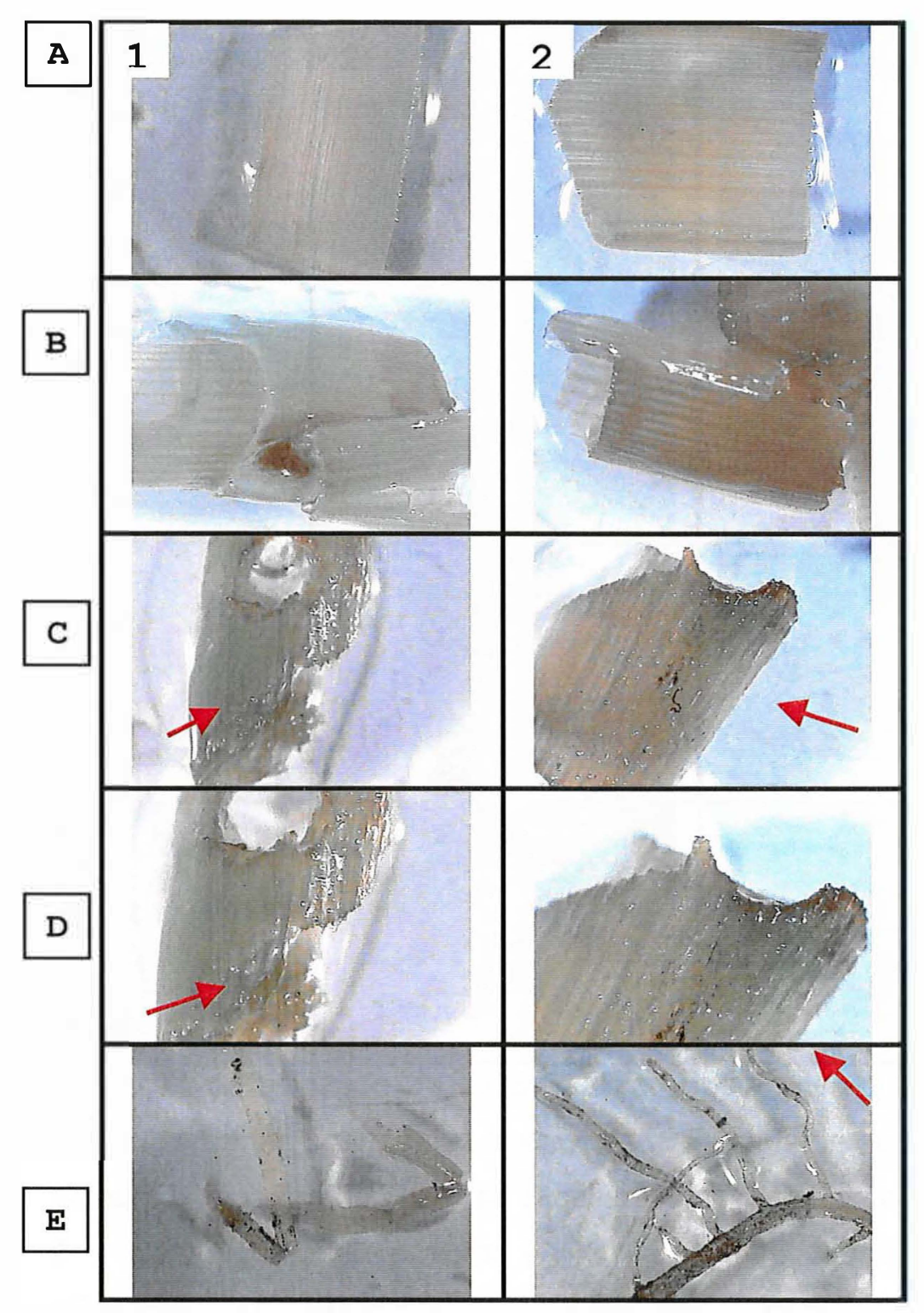

Figura 47 - Detecção da atividade da GUS, realizada pelo ensaio histoquímico, em diferentes partes das plantas transgênicas de cana-de-açúcar contendo a construção gênica pCAMBIA $1281 \mathrm{z}$ + fragmento $A-D$ expostas ao ataque de lagartas de Diatraea saccharalis. (1) = planta $1 ; 2=$ planta 2 . $(\mathbf{A})=$ porção da folha; (B) = porção do "palmito"; (C) e (D) = local do dano (porção próxima ao solo); $(\mathrm{E})$ = porção da raiz 


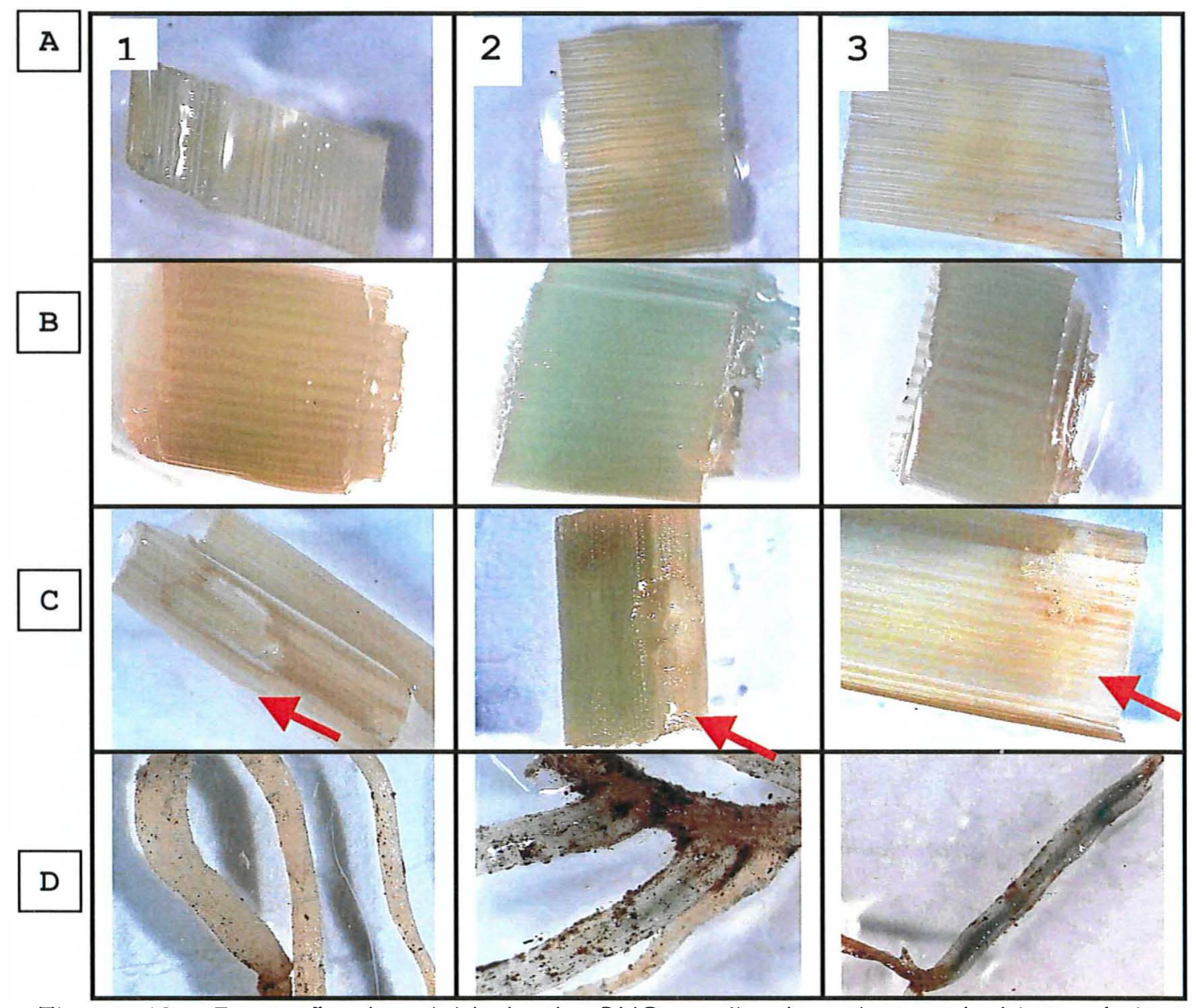

Figura 48 - Deteç̧ão da atividade da GUS, realizada pelo ensaio histoquímico, em diferentes partes das plantas transgênicas de cana-de-açúcar expostas ao ataque de lagartas de Diatraea saccharalis. (1) = planta controle negativo; 2 = planta contendo $\circ$ vetor pAHC27; $(3)=$ planta contendo $\circ$ vetor pCAMBIA 1301. (A) = porção da folha; $(\mathbf{B})=$ porção do "palmito"; $(\mathbf{C})=$ local do dano (porção próxima ao solo); (D) = porção da raiz. O local do dano está indicado com a seta

\subsection{Ensaio fluorimétrico}

Com a finalidade de quantificar e verificar a possivel resposta sistêmica da planta ao ataque das lagartas, foram analisados diferentes tecidos (folhas, 
"palmito" e região próxima ao dano) das plantas pertencentes às construções AB, A-C e A-D que apresentaram expressão da GUS.

Para isso a enzima ß-glucuronidase (GUS) foi quantificada pelo método fluorimétrico.

Nota-se pelos ensaios fluorimétrico que aumentando-se o comprimento da região promotora, aumenta-se também a atividade da GUS em resposta ao ataque da broca da cana. Os dados obtidos estão sintetizados na Figura 49.

Esse padrão de expressão da GUS, conforme o tamanho da região promotora também foi observado por Barata (2003) utilizando ensaios de regulação pela luz.

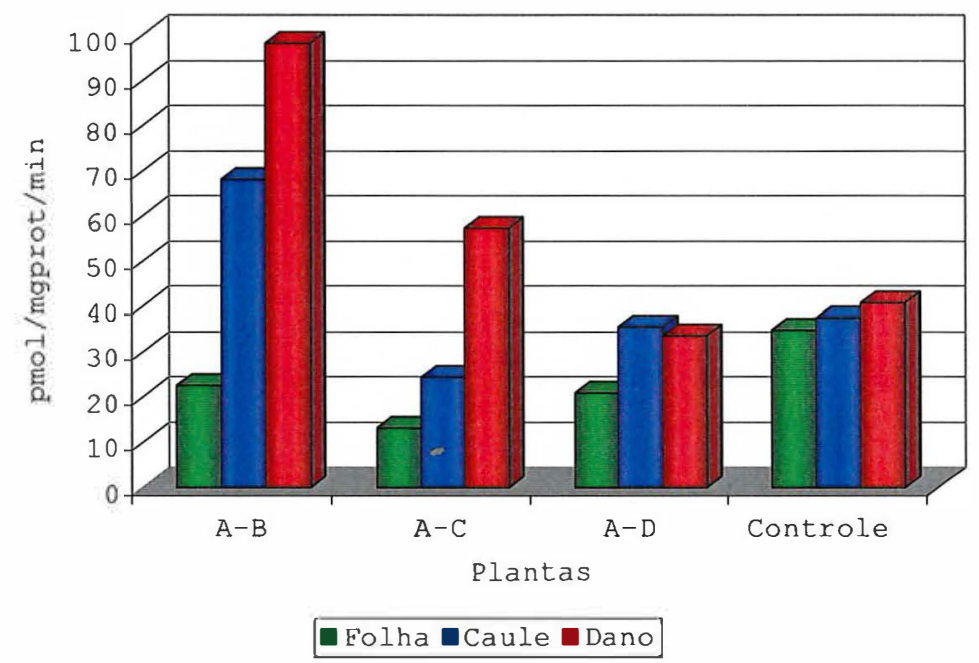

Figura 49 - Quantificação da atividade GUS, pelo método fluorimétrico, de diferentes partes das plantas transgênicas de cana-de-açúcar atacadas por lagartas de Diatraea saccharalis, contendo as construções gênicas $A-B, A-C$ e $A-D$

4.2.6.4 Análise comparativa entre as prováveis regiões promotoras do gene tipo heveína (HEL) de cana-de-açúcar e de Arabidopsis

Após o estudo das seqüências regulatórias do gene HEL de cana-deaçúcar (Figura 32) e de Arabidopsis (Figura 50), por meio do programa PLACE, foi feita a comparação entre as seqüências presentes em ambas. Na Tabela 11 estão listadas as seqüências comuns as duas HEL. 
HשL . . АATGCATCTATCTATATATCTATATATATATGAAAАTAАTAAАATTATAGGAT CAATAGTTAATTATATAATAATGTTTTTCTTGTGATTCTACGCAATTGATTTAATTACA TACGTTACAGGTAACGTGCTTAAACCATATGATACACACATGTAGGTTAAATATTTGTA TATAGATATCTGTATATTGAAATTCGTTGGATTCGATAGAATAATGAAAATATATAAT TCTGTTGTTAGATTTTTTTAAAAGAGATTCGTTACAAAATAAAAGAAAATTGGGTTTCT ССТСTTAАAАTTTCTCTACAGAATTGGAGTGCTGAAGTTTTAATAAATTAATTTTATTT GGAAAATAAAAATAAATTATGAAGTGGTATAATTTGGAATATCAATGTAATATGCTCTT TTACGAGAAATTAAGATGACCTGTGAGGGTGAGACTCCGGTGAAAAATGTGTCTAAGAA CCGTCGATATTCTTTGAACGGAAGGTCACTGGTCAAAGTCATCTGATCGGACGGTTTAT AACTAAGCATTGCGTATCTTCCCCATCGCGATACAGATAATGACTAATGAGGAGAGGCG GCTAATTGTGATTGTTTTTGTTTGTTTGTAGAAAATAGCAGCCTAGTAGATAAGAGTCG СTСTCATTTGGATAAАTATTGAATTTCGATCATTGACTAATCAAAGTTAACATAATCGG TCCATTGAATTAGCCATTTTGGATTATTTAAAATTTTTTTCTCAAAACTCACTTAGCA GTTTAACAAATTTCTTCTATGATGCGTAAGTAAAAAAGCAAATCTATCCGCTTCCTCGT ААTTTTTCTTTATTGACACGAGATGAATTTTCAGCTTTGATCTAAAATAGTATAGAGAC TGGGCTGGCGAGCCTACAGATCTTTAAGTGTTGACTTCAGTCAAAGTCAACTTGAATTG TTTGTCTATGGGCTTAACGGGCAATACGGGTTTGGTTTACCGAAACTGAGCCCATATCA AGTCCGCTTCAAATTGTTATAAGTTGGATAAAACAGAGTACACGAGAGAAAGAGAAGAG CGAAGAGAGTATTCTAGAGTGCCCGGACCAAATGGATAGGGTAGCTGTTATCGGGCCAA AGGCAATTTTTTTTCCCTAGTGTTAACCATGGCCCAAAATGTTTTTCCCCCCAAATTAC TTAATTATTGTTGGGACGAAGCTGTGCTTCTTGTTTATTTTTGTGTATCTTTCATCTTC TTGTAATCATCTTTTGTGAATCTGTTTTTTGAGACCATCTTTTGTGCATTTTGTACTT GTTAAGTTACAAGTTGTAATTCACAACGAGAGCAAAATCAGCCAATTTATATTGAACTA AGTATTCTACAAACAAGTAAATACATGTGGTGAATTTGACAACCAAGGATACAAACTAG

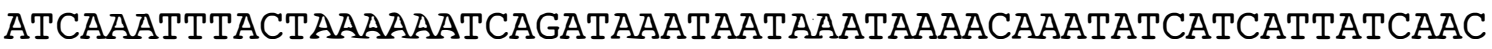
CATTGTTTGTTGAGGCAATGGATGTCGATGACAGCGTAAAGCATCAATAATGGAGCATA

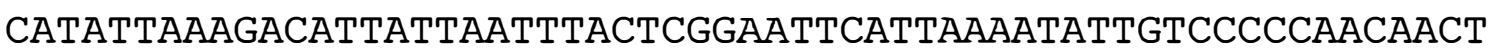

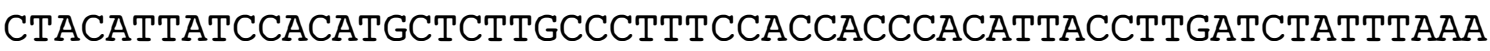
GTTTTTTCATTTGTGTTTCACCGAAAAAACACCAAAAATTGATAAATGTAATATTAGAA ATAAAAAAAAACAATAATTGAGGCCAGGCCAACCTTATTAAAAAAGAAAGAAATAGACA СTAAACACCAATTGGATCCTGTTGAGGCCAACCTTATATATACGCACGACAATAATTGG TCTTCGAGTTACATTGATACAAAAAGATCCGCACTACTAATCTTCCGTTTGTTGGTTTT ACGATTGTTAACCATCTCATGTCATTTAGCTCCACTTATTGAAAAGTTACTAAAATAAA GAATAAACAAACAAAAAGgTATAATTTAAgGTGGTTGAAAATGTTGGATA . . Auxina

Figura 50 - Seqüência da região regulatória do gene do tipo heveína (HEL) de Arabidopsis (2040 pares de base) obtida por meio do programa TAIR (http://www.arabidopsis.org)

Dentre as seqüências regulatórias comuns as duas plantas, destaca-se os motivos denominados AGC Box (AGCCGCC) e GCC Box (GCCGCC). As AGC Box são seqüências de ligação das AtERFs (ethyleneresponsive transcription factors de Arabidopsis thaliana) e que AtERF 1, 2 e 5 
agem como ativadores da GCC Box dependente de transcrição e AtERF3 e 4 atuam como repressoras. As Proteinas AtERF são fatores de sinais de resposta a estresse e são encontradas em promotores de tabaco (Suzuki et al., 1998; Higo et al., 1999). São conservadas na maioria dos genes das proteinas relacionada à patogênese - $\mathrm{PR}$ (Higo et al., 1999).

O motivo GCC Box é encontrado em muitos genes responsivos a patógenos tais como PDF1.2, Thi2.1 e PR4, do qual o HEL é homólogo (Van Damme et al., 1999).

Esse motivo funciona como elemento responsivo ao etileno e desempenha papel importante na regulação da expressão de genes responsivos ao etileno (Higo et al., 1999; Yong-Qiang et al., 2002; Chakravarthy et al., 2003).

Em Arabidopsis, de um total de 423 motivos presentes (considerando também os motivos repetidos) na região promotora 310 são iguais aos de cana. Em cana 161 motivos do total de 205 são iguais ao de Arabidopsis, ou seja, aproximadamente $70 \%$ dos motivos encontrados são comuns a ambas. 
Tabela 11. Motivos em comum presentes na regiäo promotora do gene do tipo heveína (HELL) de cana-de-açúcar e de Arabidopsis Thaliana

\begin{tabular}{|c|c|c|c|c|}
\hline \multirow{2}{*}{ Nome do fator } & \multirow{2}{*}{ Seqiência sinal } & \multirow{2}{*}{ Site } & \multicolumn{2}{|c|}{ Número de fatores } \\
\hline & & & Cana-de-açúcar & Arabidopsis \\
\hline -10PEHVPSB!D & TATrCT & S000392 & 2 & 5 \\
\hline ABRELATERDI & ACGTG & sto00414 & 8 & 1 \\
\hline ACGTATERD1 & ACGT & S000415 & 14 & 4 \\
\hline AGCBOXNPGLB & AGCCGCO & $\$ 000232$ & 1 & 1 \\
\hline BOXIINTPATPB & ATAGAA & s000296 & 2 & 2 \\
\hline CARGCWBGAT & 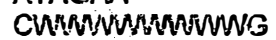 & 5000431 & 2 & 6 \\
\hline CAATBOX1 & CAAT & 5000028 & 5 & 36 \\
\hline CATATGEMSAUR & CATATS & $\$ 000370$ & 2 & 2 \\
\hline CCAATBOX1 & CCAAT & s000030 & $\overline{2}$ & 7 \\
\hline CGACGOSAMYY & CGACG & S000205 & 4 & 1 \\
\hline DOFCOREZM & AAAG & 5000265 & 11 & 27 \\
\hline DPBFCOREDCDC3 & ACACNING & $\$ 000292$ & 4 & 4 \\
\hline EBOXBNNAPA & CANNTG & 5000144 & 14 & 20 \\
\hline GATABOX & GATA & 5000039 & 8 & 27 \\
\hline GCCCORE & GCCGCC & 5000430 & 7 & 1 \\
\hline GT1CONSENSUS & GRWAAW & S000198 & 3 & 28 \\
\hline GTGANTG10 & GTGA & 5000378 & 16 & 11 \\
\hline IBOX & GATAAG & So00124 & $\therefore \therefore$ & 1 \\
\hline IBOXCORE & GATAUS & S000199 & 3 & 9 \\
\hline MYB1AT & WAACCA & 5000408 & 2 & 5 \\
\hline MYBZCONSENSUSAT & YAACKG & 5000409 & $i$ & 1 \\
\hline MYBCORE & CNGTTR & $\$ 000176$ & 3 & 4 \\
\hline MYBST1 & GGATA & 5000180 & 1 & 7 \\
\hline MYCATERD1 & CATGTG & Sov00413 & 1 & 3 \\
\hline MYCATRED22 & CACATG & 5000174 & $i$ & 3 \\
\hline MYCCONSENSUSAT & CANNTG & $\$ 000407$ & 15 & 20 \\
\hline PALBOXAPC & CCGTEC & sono137 & 1 & 1 \\
\hline POLASIG3 & AATAAT & S000088 & 2 & 11 \\
\hline POLLEN1LELAT52 & AGAAA. & scoci245 & 3 & 15 \\
\hline PYRIMIDINEBOXOSRAMYYA & CCTTाT & $\$ 000259$ & 1 & 1 \\
\hline R.AV1AAT & CAACA & 5000314 & $i$ & 8 \\
\hline REALPHALGLHCB21 & AACCAA & $\$ 000362$ & $i$ & 3 \\
\hline ROOTIMOTIFTAPOX1 & ATATI & $\$ 000028$ & i & 18 \\
\hline SEFAMOTIFGMTS & RTTTTR & S000103 & $i$ & 4 \\
\hline SP8BFIBSPaBIB & TACTATT & S000184 & $i$ & 1 \\
\hline TAAAGSTKST1 & TAAAC & 5000387 & 2 & 6 \\
\hline TATABOX 4 & TATATAA & S000111 & 1 & 4 \\
\hline TRANSINITDICOTS & AMPNAUGGC & 5000201 & $i$ & 1 \\
\hline TRANSINITMONOCOTS & RMNAAUGGC & Sop0202 & 3 & 1 \\
\hline
\end{tabular}




\section{CONCLUSÕES}

Tendo em vista os resultados apresentados, concluiu-se que:

$>$ Os genes estudados: polifenol oxidase (PPO), lipoxigenase (LOX2), metalotioneína (MT1), proteína do tipo heveína (HEL) e cistatina (C/S) são induzidos em cana-de-açúcar pelo ataque da broca da cana (Diatraea saccharalis);

$>$ A seqüência de nucleotídeos isolada (região promotora) a partir da região 5' do gene do tipo heveína (HEL) de cana-de-açúcar, por meio da técnica PCR-TAIL, apresenta regiões regulatórias próprias de região promotora, inclusive com motivos relacionados à defesa da planta;

$>$ A região promotora do gene do tipo heveína isolada de cana-de-açúcar responde ao estímulo do ataque por Diatraea saccharalis;

A região promotora do gene do tipo heveína (HEL) de cana-de-açúcar possui motivos semelhantes aos encontrados no gene ortólogo de Arabidopsis thaliana. 


\section{REFERÊNCIAS BIBLIOGRÁFICAS}

ABRANTES, A.P.Q. O mercado promissor e plantio direto na palhada de cana crua. Informativo Agropecuário, v.18, n.204, p.14, 2003.

AKELLA, V.; LURQUIN, P.F. Expression in cowpea seedlings of chimeric transgenes after electroporation into seed-derived embryos. Plant Cell Reports, v.12, n.1, p.110-117, 1993.

ALBORN, H.T.; TURLINGS, T.C.J.; JONES, T.H.; STENHAGEN, G.; LOUGHRIN, J.H.; TUMLINSON, J.H. An elicitor of plant volatiles from beet armyworm oral secretion. Science, v.276, n.5314, p.945-949, 1997.

ALTSCHUL, S.F.; MADDEN, T. L.; SCHAFFER, A. A.; ZHANG, J.; ZHANG, Z.; MILLER, W.; LIPMAN, D.J. Gapped BLAST and PSI-BLAST: a new generation of protein database search programs. Nucleic Acids Research, v. 25, n.17, p. 3389-3402, 1997.

AUSUBEL, F.M. Current Protocols in Molecular Biology. Havard: John Wiley \& Sons, 1994.

BALDWIN, I.T.; PRESTON, C.A. The eco-physiological complexity of plant responses to insect herbivores. Planta, v. 208, n.2, p.137-145, 1999. 
BARATA, R.M. Clonagem, caracterização da expressão gênica e do transporte intra-organelar da protease FtsH-p1 de tomate (Lycopersicon esculentum Mill. Cv. Micro Tom). Piracicaba, 2003. 123p. Tese (Doutorado) - Escola Superior de Agricultura "Luiz de Queiroz", Universidade de São Paulo.

BASTOS, E. Cana-de-açúcar - o verde mar de energia. Coleção Brasil Agrícola. São Paulo: Ícone, 1987. 130p.

BELLUCCI, M.; PUPILLI, F.; ARCIONI, S. Variation for polyphenol oxidase activity in stems of Medicago species. Agronnomie, v.9, n.1, p.73-77,1999.

BELZUNCES, L.P.; LENFANT, C.; DIPASQUALE, S.; COLIN, M.E. In vivo and in vitro effects of Wheat-Germ-Agglutinin and Bowman-Birk soybean trypsininhibitor, 2 potencial transgene products, on midgut esterase and protease acitivities from Apis mellifera. Comparative Biochemistry and Physiology Part B: Biochemistry and Molecular Biology, v.109, n.1, p.63-69, 1994.

BENTO, J.M.S. Perdas por insetos na agricultura. Ação Ambiental, v.2, n.4, p.19-21. 1999.

BERGEY, D.R.; HOWE, G.A.; RYAN, C. Polypeptide signaling for plant defensive genes exhibits analogies to defense signaling in animals. Proceedings of the National Academy of Sciences of the United States of America, v.93, n.22, p.12053-12058, 1996.

BIRKEMEIER, G.F.; RYAN, C.A. Wound signaling in tomato plants. Evidence that $A B A$ is not a primary signal for defense gene activation. Plant Physiology, v.117, n.2, p.687-693, 1998. 
BOHLMANN, H.; APEL, $K$. Isolation and characterization of cDNAs coding for leaf-specific thionins closely related to the endosperm-specific hordothionin of barley (Hordeum vulgare L.). Molecular \& General Genetics, v.207, n.23, p.446-454, 1987.

BOSS, P.; GARDNER, R.; JANSSEN, B.; ROSS, G. An apple polyphenol oxidase cDNA is up-regulated in wounded tissues. Plant Molecular Biology, v.27, n.2, p.429-433, 1995.

BOSTOCK, R.M. Signal conflicts and synergies in induced resistance to multiple attackers. Physiological and Molecular Plant Pathology, v. 55, n.2, p.99-109, 1999.

BOTELLA, M.A.; XU, Y.;PRABHA, T.N.; ZHAO, Y.; NARASIMHAN, M.L.; WILSON, K.A.; NIELSEN, S.S.; BRESSAN, R.A.; HASEGAWA, P.M. Differential expression of soybean cysteine proteinase inhibitor genes during development and in response to wounding and methyl jasmonate. Plant Physiology, v.112, n.3, p.1201-1210, 1996.

BRASILEIRO, A.C.M.; CARNEIRO, V.T.de C. (Ed.) Manual de transformação genética de plantas. Brasilia: SPI/Embrapra, Cenargem, 1998. 309p.

BRITO, L.O.; LOPES, A.R.; PARRA, J.R.P.; TERRA, W.R.; SILVA-FILHO, M.C. Adaption of tobacco budworm Heliothis virescens to proteinase inhibitors may be mediated by synthesis of new proteinase. Comparative Biochemisty and Physiology, v.128B, n.2, p.365-375, 2001. 
BROADWAY, R. \& DUFFEY, S. Plant proteinase inhibitors: Mechanism of action and effects on the growth and digestive physiology of larval Heliothis zea and Spodoptera exigua. Journal of Insect Physiology, v 32, n.10, p. 827-833, 1986.

BROEKAERT, W.; LEE, H.; KUSH, A.; CHUA, N.H.; RAIKHEL, N. Woundinduced accumulation of $m R N A$ containing a hevein sequence in laticifers of rubber tree (Hevea brasiliensis). Proceedings of the National Academy of Sciences of the United States of America, v.87, n.19, p.7633-7637, 1990.

BROEKAERT, W.F., MARIEN, W., TERRA, F.R., DE BOLLE, M.F., PROOST, P., VAN DAMME, J., DILleN, L., ClAEYS, M., REES, S.B., VANDERLEYDEN, J. Antimicrobial peptides from Amaranthus caudatus seeds with sequence homology to the cysteine/glycine-rich domain of chitinbinding proteins. Biochemistry, v.31, n.17, p.4308-4314, 1992.

BROWN, R.L.; KAZAN, K.; McGRATH, K.C.; MACLEAN, D.J.; MANNERS JM. A role for the GCC-box in jasmonate-mediated activation of the PDF1.2 gene of Arabidopsis. Plant Physiology, v.132, n.2, p.1020-1032, 2003.

BRUXELLES, G.L.; ROBERTS, M.R. Signal regulating multiple responses to wounding and herbivores. Critical Reviews in Plant Sciences, v.20, n.5, p.487-521, 2001.

BUGOS, R.C., and THOM, M. Glucose transporter CDNAs from sugarcane. Plant Physiology, v.103, n.4, p.1469-1470, 1993.

BUTLER, J.E.F.; KADONAGA, J.T. The RNA polymerase II core promoter: a key component in the regulation of gene expression. Genes and Development, v.16, n.20, p.2583-2592, 2002. 
CARLINI, C.R.; GROSSI-DE-SÁ, M.F. Plant toxic proteins with insecticidal properties. A review on their potentialities as bioinsecticides. Toxicon, v.40, n.8, p.1515-1539, 2002.

CASTILHO, H.J. Introdução de Apanteles flavipes (Cam., 1891) (Hymenoptera, Braconidae) para o controle biológico da broca da cana-de-açúcar Diatraea saccharalis (Fabr., 1794) (Lepidoptera, Pyralidae), na região de Santa Bárbara D'Oeste, SP . Piracicaba, 1982. 79p. Dissertação (Mestrado) Escola Superior de Agricultura "Luiz de Queiroz" , Universidade de São Paulo.

CHAKRAVARTHY, S.; TUORI, R.P.; D'ASCENZO, M.D.; FOBERT, P.R.; DESPRÉS,C.; MARTIN, G.B. The tomato transcription factor Pti4 regulates defense-related gene expression via GCC box and non-GCC box cis elements. The Plant Cell, v.15, n.12, p.3033-3050, 2003.

CHEONG, Y.H.; CHANG, H.S.; GUPTA, R.; WANG, X.; ZHU, T.; LUAN, S. Transcriptional profiling reveals novel interactions between wounding, pathogen, abiotic stress, and hormonal responses in Arabidopsis. Plant Physiology, v.129, n.2, p.661-677, 2002.

CONSTABEL, C.P.; BERGEY, D.R.; RYAN, C.A. Systemin activates synthesis of wound-inducible tomato leaf polyphenol oxidase via the octadecanoid defense signaling pathway. Proceedings of the National Academy of Sciences of the United States of America, v.92, n.2, p.407-411, 1995.

CONSTABEL, C.P.; YIP, L.; RYAN, C.A. Prosystemin from potato, black nightshade, and bell pepper: primary structure and biological activity of predicted systemin polypeptides. Plant Molecular Biology, v.36, n.1, p.5562, 1998. 
CONSTABEL,C.P.; LYNN, Y; PATTON, J.J.; CHRISTOPHER, M.E. Polyphenol oxidase from hybrid poplar. Cloning and expression in response to wounding and herbivory. Plant Physiology, v.124, n.1, p.285-295, 2000.

CREELMAN, R.A.; MULLER, J.E. Biosynthesis and action of jasmonate in plants. Annual Review of Plant Molecular Biology, v.48, p.355-387, jun/1997.

DATTA, K.; MUTHUKRISHNAN, S.; DATTA, S.K. Expression and function of PR-protein genes in transgenic plants. In: DATA, S.K.; MUTHUKRISHNAN, S. Pathogenesis-related proteins in plants. New York: CRC Press, 1999. cap.13, p.261-277.

DE MORAES, C.M.; LEWIS, W.J.; PARE, P.W.; ALBORN, H.T.; TUMLINSON, J.H. Herbivore-infested plants selectively attract parasitoids. Nature, v.393, n.6685, p.570-573, 1998.

DUAN, X.; LI, X.; XUE, Q.; ABO-EL-SAAD, M.; XU, D.; WU, R. Transgenic rice plants harboring an introduced potato proteinase inhibitor II gene are insect resistant. Nature Biotechnology, v.14, n.4, p.494-498, 1996.

EPPLE, P.; APEL, K.; BOHLMANN, H. ESTs reveal a multigene family for plant defensins in Arabidopsis thaliana. FEBS Letters, v.400, n.2, p.168-172, 1997.

FALCO, M.C.; SILVA-FILHO, M.C. Expression of soybean proteinase inhibitors in transgenic sugarcane plantas: effects on natural defense against Diatraea saccharalis. Plant Physiology and Biochemistry, v.41, n.8, p.761-766, 2003. 
FALCO, M.C.; TULMANN NETO, A.; ULIAN, E.C. Transformation and expression of a gene for herbicide resistance in Brazilian sugarcane. Plant Cell Report, v.19, n.12, p.1188-1194, 2000.

FALCO, MC; POMPERMAYER, P; LOPES, FCC; SILVA-FILHO, MC Mechanisms of sugarcane response to herbivory. Genetics and Molecular Biology, v.24, n.1-4, p.113-122, 2001.

FARMER, E.E.; WEBER, H.; VOLLENWEIDER, S. Fatty acid signaling in Arabidopsis. Planta, v.206, n.2, p.167-174, 1998.

FELTON, G.W.; DONATO, K.K.; BROADWAY, R.; DUFFEY, S.S. Impact of oxidized plant phenolics on the nutritional quality of dietary protein to a noctuid herbivore, Spodoptera exigua. Journal of insect Physiology, v.38, n.4, p.277-285, 1992.

FNP CONSULTORIA \& COMERCIO, 2000. Agrianual: Anuário da Agricultura Brasileira. São Paulo, 2003. p.249-269: cana-de-açúcar.

GATEHOUSE, J.A. Plant resistance towards insect herbivores: a dynamic interaction. New Phytologist, v.156, n.2, 145-169, 2002.

GAUSING, K. Thionin genes specifically expressed in barley leaves. Planta, v.171, n.2, p.241, 1987.

GREEN, T.R.; RYAN, C.A. Wound-induced proteins inhibitors in plant leaves: a possible defense mechanism against insects. Science, v.175, n.4023, p.776-777, 1972. 
GUEVARA, L.A.C. Aspectos da biologia em condições naturais e freqüência de acasalamento da Diatraea saccharalis (Fabr., 1794) (Lepidoptera Crambidae) a broca da cana-de-açúcar. Piracicaba, 1976. 70p. Dissertação (Mestrado) - Escola Superior de Agricultura "Luiz de Queiroz" , Universidade de São Paulo.

HEHL, R.; WINGENDER, E. Database-assisted promoter analysis. Trends in Plant Science, v.6, n.6, p.251-255.2001.

HEITZ, T.; BERGEY, D.; RYAN, C.A. A gene encoding a chloroplast-targeted lipoxygenase in tomato leaves is transiently induced by wounding, systemin, and methyl jasmonate. Plant Physiology, v.114, n.3, p.1085-1093, 1997.

HIGO, K.; UGAWA, Y.; IWAMOTO, M. KORENAGA, T. Plant cis-acting regulatory DNA elements (PLACE) database:1999. Nucleic Acids Research, v.27, n.1, p. 297-300, 1999.

HOWE, G.A., LIGHTNER, J., AND RYAN, C.A. An octadecanoid pathway mutant (JL5) of tomato is compromised in signaling for defense agaisnt insect attack. Plant Cell, v.8, n.11, p.2067-2077, 1996.

HUANG, R.-H., XIANG, Y., LIU, X.-Z., ZHANG, Y., HU, Z., WANG, D.-C. Two novel antifungal peptides distinct whith a five disulfide motil from the bark of Eucommia ulmoides Oliv. FEBS Letters, v.521, n.1-3, p.87-90, 2002.

JANZEN, D.H.; RYAN, C.A.; LIENER, I.E.; PEARCE, G. Potentially defensive proteins in mature seeds of 59 species of tropical leguminosae. Journal of Chemistry Ecology, v.12, n.6, p.1469-80, 1986. 
JOUANIN, L.; BONADÉ-BOTTINO, M.; GIRARD, C.; MORROT, G.; GIBAND, M. Transgenic plants for insect resistance. Plant Science, v.131, n.1, p.111, 1998.

KESSLER, A.; BALDWIN, I.T. The emerging molecular analysis. Annual Review of Plant Biology, v.53, p.299-328, 2002.

KING, E.G.; HARTLEY, G.G. Diatreae saccharalis.In: SINGH, P.; MOORE, R.F. Handbook of insect rearing. Amsterdam: Elsevier Science, 1985. v.2, p.265-270.

KOIWA, H.; BRESSAN,R.A.; HASEGAWA, P.M. Regulation of protease inhibitors and plant defense. Trends in Plant Science, v.2, n. 10, p.379-384, 1997.

KOO, J.C.; CHUN, H.J.; PARK, H.C.; KIM, M.C.; KOO, Y.D.; KOO, S.C.; OK, H.M.; PARK, S.J.; LEE, S.H.; YUN, D.J.; LIM, C.O.; BAHK, J.D.; LEE, S.Y.; $\mathrm{CHO}$, M.J. Over-expression of a seed specific hevein-like antimicrobial peptide from Pharbitis nil enhances resistance to a fungal pathogen in transgenic tobacco plants. Plant Molecular Biology, v.50, n.3, p.441-452, 2002.

KOO, J.C., LEE, S.Y., CHUN, H.J., CHEONG, Y.H., CHOI, J.S., KAWABATA, S., MIYAGI, M., TSUNASAWA, S., HA, K.S., BAE, D.W., HAN, C.D., LEE, B.L., CHO, M.J. Two hevein homologues isolated from the seeds of Pharbitis nil L. exhibit potent antifungal activity. Biochimica et Biophysica Acta, v.1382, n.1, p.80-90, 1998. 
KORTH, K.L.; DIXON, R.A. Evidence for chewing insect-specific molecular events distinct from a general wound response in leaves. Plant Physiology, v.115, n.4, p.1299-1305, 1997.

LAUDERT, D.L.; PFANNSCHMIDT, U.; LOTTSPEICH, F.; HOLLANDERCZYTKO, H.; WEILER, E.W. Cloning, molecular and functional characterization of Arabidopsis thaliana allene oxide synthase (CYP 74), the first enzyme of the octadecanoid pathway to jasmonates. Plant Molecular Bioology, v. 32, n. 2, p.323-335, 1996

LEE, J.M.; ANSTEE, J.H. Endoproteases from the midgut of larval Spodoptera littoralis include a chymotrypsin-like enzyme with an extended binding site. Insect Biochemistry and Molecular Biology, v.25, n.1, p.49-61, 1995.

LEE, O.S.; LEE, B.; PARK, N. et al. Pn-AMPs, the hevein-like proteins from Pharbitis nil confers disease resistance against phytopathogenic fungi in tomato, Lycopersicum esculentum. Phytochemistry, v.62, n.7, p.1073-1079, 2003.

LÉON, J.; ROJO, E.; SÁNCHEZ-SERRANO, J. J. Wound signalling in plants. Journal of Experimental Botany, v.52, n.354, p.1-9, 2001.

LIU, Y.; WHITTIER, R.F. Thermal asymmetric interlaced PCR: Automatable amplification and sequencing of insert end fragments from P1 and Yac clones for chromossome walking. Genomics, v.25, n.3, p.674- 681, 1995.

MACEDO, N. Comportamento varietal, mecanismo e herdabilidade da resistência da cana-de-açúcar ao ataque de Diatraea saccharalis (Fabr., 1794). Piracicaba, 1978. 88p. Tese (Doutorado) - Escola superior de Agricultura "Luiz de Queiroz", Universidade de São Paulo. 
MARTIN, F.A.; RICHARD, C.A.; HENSLEY,S.D. Host resistence to Diatraea saccharalis (F.): Relationship of sugarcane internode hardness to larval damage. Environmental Entomology, v.4, n.5, p.687-688,1975.

McCONN, M., AND CREELMAN, R.A., BELL, E., MULLET, J.E., AND BROWSE, J. Jasmonate is essential for insect defense in Arabidop-sis. Proceedings of the National Academy of Sciences of the United States of America, v.94, n.10, p.5473-5477, 1997.

MELLO, M.O.; SILVA-FILHO, M.C. Plant-insect interactions: an evolutionary arms race between two distinct defense mechanisms. Brazilian Journal of Plant Physiology, v.14, n.2, p.71-81, 2002.

MELLO, M.O.; TANAKA, A.S.; SILVA-FILHO, M.C. Molecular evolution of Bowman-Birk type proteinase inhibitors in flowering plants. Molecular Phylogenetics and Evolution, v.27, n.1, p.103-112, 2003.

NEUHAUS, J.M. Plant chitinases. In: DATA, S.K.; MUTHUKRISHNAN, S. (Ed.) Pathogenesis-related proteins in plants. New York: CRC Press, 1999. cap. 4, p.77-105.

NIELSEN, K.K., NIELSEN, J.E., MADRID, S.M., MIKKELSEN, J.D. Characterization of a new antifungal chitin-binding peptide from sugar beet leaves. Plant Physiology, v.113, n.2, p.83-91, 1997.

OHME-TAKAGI, M.; SUZUKI, K.; SHINSHI, H. Regulation of ethylene-induced transcription of defense genes. Plant Cell Physiology, v. 41, n.11, p. 11871192, 2000. 
PANDA, N.; KHUSH, G.S. Breeding for resistance to insects. In: PANDA, N.; $\mathrm{KHUSH}$, G.S. Host plant resistance to insects. Wallingford: CAB International, 1995. cap.11, p.324-355.

PARÉ, P.W.; TUMLINSON, J.H. De novo biosynthesis of volatiles induced by insect herbivory in cotton plants. Plant Physiology, v.114, n.4, p.11611167, 1997.

PAULILLO, L.C.M.; LOPES, P.T.; CRISTOFOLETTI, P.T.; PARRA, J.R.P.; TERRA, W.R.; SIVA-FILHO, M.C. Changes in midgut endopeptidase activity of Spodoptera frugiperda (Lepdoptera: Noctuidae)are responsible for adaptation to soybean proteinase inhibitors. Journal of Economic Entomology, v.93, n.3, p.892-896, 2000.

PEARCE, G.; MOURA, D.S.; STRATMANN, J.; RYAN, C.A. Production of multiple plant hormones from a single polyprotein precursor. Nature, v.411, n.6839, 2001.

PEÑA-CORTES, H.; SANCHEZ-SERRANO, J.; ROCHA-ROSA, M.; WILLMITZER, L. Systemic induction of proteinase-inhibitor-II gene expression in potato plants by wounding. Planta, v.174, p.84-89, 1988.

POMPERMAYER, P.; FALCO, M. C.; PARRA, J. R. P.; SILVA FILHO, M. C. Coupling diet quality and Bowman - Birk and Kunitz - type soybean proteinase inhibitor effectiveness to Diatraea saccharalis development and mortality. Entomologia Experimentalis et Applicata, v.109, n.3, p.217 224, 2003. 
POMPERMAYER, P.; LOPES, A.R.; TERRA, W.R.; PARRA, J.R.P.; FALCO, M.C.; SILVA-FILHO, M.C. Effects of the soybean proteinase inhibitors on development, survival and reproductive potential of the sugarcane borer, Diatraea saccharalis. Entomologia Experimentalis et Applicata, v.99, n.1, p.79-85, 2001.

POTTER, S.; UKNES, S.; LAWTON, K.; WINTER, A.M.; CHANDLER, D.; DIMAIO, J.; NOVITZKY, R.; WARD, E.; RYALS, J. Regulation of a heveinlike gene in Arabidopsis. Molecular Plant-microbe interactions, v.6, n.6, p.680-685, 1993.

REDMAN, J.; WHITCRAFT, J.; JHONSON, C.; ARIAS J. Abiotic and biotic stress differentially stimulate as-1 element activity in Arabidopsis. Plant Cell Report, v.21, n.2, p.180-185, 2002.

REIS, E.M.; MARGIS, R. Sugarcane phytocystatins: identification, classification and expression pattern analysis. Genetics and Molecular Biology, v.24, n.1-4, p.291-296, 2001.

REYMOND, P.; FARMER, E.E. Jasmonate and salicylate as global signals for defense gene expression. Current Opinion in Plant Biology, v.1, n.5, p.404-411, 1998.

REYMOND, P.; WEBER, H.; DAMOND, M.; FARMER, E. E. Differential gene expression in response to mechanical wounding and insect feeding in Arabidopsis. The Plant Cell, v.12, n.5, p.707-719, 2000. 
ROBERTS, C.S.; RAJAGOPAL, S.; SMITH, L.A.; NGUYEN, T.A.; YANG, W.; NUGROHO, S.; RAVI, K.S.; CAO, M.L.; VISAYACHANDRA, K.; PATELLI,V.; HARCOURT, R.L.; DRANSFIELD, L.; DESAMERO, N.; SLAMET, I.; KEESE, P.; KILIAN, A.; JEFFERSON, R.A. A comprehensive set of modular vectors for advanced manipulations and efficient transformation of plants by both Agrobacterium and direct DNA uptake methods: PCAMBIA vector release manual versions 3.05. New York: CRC Press. 1997. 6p.

ROJO, E.; LEON, J.; SANCHEZ-SERRANO Cross-talk between wound signaling patrways determines local versus systemic gene expression in Arabidopsis thaliana Plant Journal, v.20, n.2, p.135-142, 1999.

ROMBAUTS, S.; FLORQUIN, K.; LESCOT, M.; MARCHAL, K.; ROUZÉ, P.; VAN DE PEER, Y. Computational approaches to identify promoters an cisregulatory elements in plant genomes. Plant Physiology, v.132, n.3, p.1162-1176, 2003.

ROOK, F.; BEVAN, M.W. Genetic approachs to understanding sugar response pathways. Journal of Experimental Botany,v.54, n.382, p.495-501, 2003.

RYAN, C.A. Protease inhibitors in plants: genes for improving defenses against insects and pathogens. Annual Review Phytopathology, v.28, p.425-449, 1990.

RYAN, C.A. The systemin signaling pathway: differential activation of plant defensive genes. Biochimica et Biophysica Acta, v.1477, n.1-2, p.112-121, 2000. 
RYAN, C.A.; PEARCE, G. Polypeptide hormones. Plant Physiology, v.125, n.1 p.65-68, 2001.

RYAN, C.A.; PEARCE, G. SCHEER, J.; MOURA, D.S. Polypeptide hormones. The Plant Cell, v.14, n.5, p.S251-S264, may/2002.

SAMBROOK J, FRITSCH EF, MANIATIS T. Molecular cloning: a laboratory manual. 2.ed. New York: Cold Spring Harbor Laboratory, 1989. 3v.

SAMBROOK, J.; RUSSEL, D.W. Molecular cloning: a laboratory manual. 3.ed. New York: Cold Spring Harbor Laboratory, 2001. 3v.

SETTO, M.M. Demanda mundial indica safra açúcareira. Jornal de Piracicaba. Caderno de Economia, Piracicaba, 21 mar. 2004. p.B1.

SGRILLO, R.B. Desenvolvimento de modelo matemático para população da broca da cana-de-açúcar, Diatraea sacharalis (Fabr., 1794) e simulação da técnica do indivíduo estéril. 1979. 189p. Dissertação (Doutorado) - Escola Superior de Agricultura "Luiz de Queiroz" , Universidade de São Paulo.

SHETON, A.M.; ROY, C.W.; NORTH, R.C.; DICKSON, M.H.; BARNARD, J. Analyses of resistance in cabbage varieties to damage by Lepidoptera and Thysanoptera Journal of Economic Entomology, v.17, n.3, p.634-640, 1988.

SOARES-COSTA, A.; BELTRAMINI, L.M.; THIEMANN, O.H.; HENRIQUESILVA, F. A sugarcane cystatin: recombinant expression, purification, and antifungal activity, Biochemical and Biophysical Research Communications, v.296, n.5, p.1194-1199, 2002. 
STICHER, L.; MAUCH-MANI, B.; METRAUX, J.P. Systemic acquired resistance. Annual Review Phytopathology, v.35, p.235-70, 1997.

STRATMANN, J.W.; RYAN, C.A. Myelin basic protein kinase activity in tomato leaves is induced systemically by wounding and increases in response to systemin and oligosaccharide elicitors. Proceedings of the National Academy of Sciences of the United States of America, v.94, n.20, p.11085-11089, 1997.

SUZUKI, K.; SUZUKI, N.; OHME-TAKAGI, M.; SHINSHI, H. Immediate early induction of mRNA for ethylene-responsive transcription factors in tobacco leaf strips after cutting. The Plant Journal, v.15, n.5, p.657-665, 1998.

TERRA, W.R.; FERREIRA, C. Insect digestive enzymes: properties, compartmentalization and function. Comparative Biochemistry and Physiology, v.109B, n.1, p.1-62, 1994.

THIPYAPONG, P.; HUNT, M. STEFFENS, J. Systemic wound induction of potato (Solanum tuberosum) polyphenol oxidase. Phytochemistry, v.40, n.3, p.673-676, 1995.

THOMMA, B.P.H.J.; EGGERMONT, K.; PENNINCKX, I.A.M.A.; MAUCH-MANI, B.; VOGELSANG, R.; CAMMUE, B.P.A.; BROEKAERT, W.F. Separate jasmonate-dependent and salicylate-dependent defense-response pathways in Arabidopsis are essencial for resistance to distinct microbial pathogens. Proceedings of the National Academy of Sciences of the United States of America, v.95, n.25, p.15107-15111, 1998. 
VALSECHI, O.; OLIVEIRA, E.R. de; BARBIN, D.; NOVAES, F.V. Estudos sobre alguns efeitos da broca (Diatraea saccharalis) na cana-de-açúcar e seus reflexos na indústria açúcareira. Piracicaba, 1976. 142p. Tese (LivreDocência) - Escola superior de Agricultura "Luiz de Queiroz", Universidade de São Paulo.

VAN DAMME, E.J., CHARELS, D., ROY, S., TIERENS, K., BARRE, A., MARTINS, J.C. ROUGE, P., VAN LEUVEN, F., DOES, M., PEUMANS, W.J. A gene encoding a hevein-like protein from elderberry fruits is homologous to PR-4 and class V chitinase genes. Plant Physiology, v.119, n.4, p.15471556, 1999.

VENDRAMIM, J.D. Técnicas para avalização da infestação de Diatraea saccharalis (Fabr., 1794) (Lepidóptera-Pyralidae) em cultivares de cana-deaçúcar, com base no complexo broca-podridões. Piracicaba, 1987. 156p. Tese (Livre-Docência) - Escola superior de Agricultura "Luiz de Queiroz", Universidade de São Paulo.

VENDRAMIM, J.D.; NISHIKAWA, M.A.N. Melhoramento para resistência a insetos. In: NASS, L.L.; VALOIS, A.C.C.; MELO, I.S.; VALADARES-INGLIS, M.C. (Ed.) Recursos Genéticos e melhoramento - Plantas. Rondonópolis: Fundação MT, 2001. cap.24, p.737-781.

VETTORE, A.L.; DA SILVA, F.R.; KEMPER, E.L. et al. Analysis and functional annotation of an expressed sequence tag collection for tropical crop sugarcane. Genome Research, v.13, n.12, p.2725-2735, 2003.

VETTORE, A.L.; DA SILVA, F.R.; KEMPER, E.L.; ARRUDA, P. The libraries that made SUCEST. Genetics and Molecular Biology, v.24, n.1-4, 2001. 
WALKER-SIMMONS, M.; HOLLÄNDER-CZYTKO, H.; ANDERSEN, J.K.; RYAN, C.A. Wound signals in plants: a systemic plant wound signal alters plasma membrane integrity. Proceedings of the National Academic of Science of the USA, v.81, n.12, p.3737-3741, 1984.

WEI, H.; ALBERT, H.H.; MOORE, P.H. Differential expression of sugarcane polyubiquitin genes and isolation of promoters from two highly-expressed members of the gene family. Journal of Plant Physiology, v. 155, n.4-5, p.513-519, 1999.

WILDON, D.C.; THAIN, J.F.; MINCHIN, P.E.H.; GUBB, I.R.; REILLY, A.J.; SKIPPER, Y.D.; DOHERTY, H.M.; O'DONNELL, P.J.; BOWLES, D.J. Electrical signaling and systemic proteinase inhibitor induction in the wounded plant. Nature, v.360, n.6399, p.62-65, 1992.

XING, T.; JORDAN, M. Genetic engineering of plant signal tranduction mechanisms. Plant molecular Biology Reporter, v.18, n.4, p.309-318, 2000.

YODA, H.; SANO, H. Activation of hypersensitive response genes in the absence of pathogens in transgenic tobacco plants expressing a rice small GTPase. Planta, v.217, n.6, p.993-997, 2003.

YONG-QIANG, G.; WILDERMUTH, M.C.; CHAKRAVARTHY, S.; YING-TSU, L.; YANG,C.; XIAOHUA, H.; HAN, Y.; MARTIN, G.B. Tomato transcription factors Pti4, Pti5, and Pti6 activate defense responses when expressed in Arabidopsis. The Plant Cell, v.14, n.4, p.817-831, 2002. 
YOSHIDA, K.; SHINMYO, A. Transgene expression systems in plant, a natural bioreactor. Journal of Bioscience and Bioengineering, v.90, n.4, p.353$362,2000$.

ZHAO, Y.; c, M.A.; SUBRAMANIAN, L.; NIU, X.; NIELSEN, S.S.; BRESSAN, R.A.; HASEGAWA, P.M. Two wound-inducible soybean cysteine proteinase inhibitors have greater insect digestive proteinase inhibitory activities than a constitutive homologue. Plant Physiology, v.111, n.4, p.1299-1306, 1996.

ZHOU, J.M. Signal transduction and pathogen-induced PR gene expression. In: DATA, S.K.; MUTHUKRISHNAN, S. (Ed.). Pathogenesis-related proteins in plants. New York: CRC Press, 1999. cap.9, p.195-206. 